THE BRIDE OF THE DESERT 



\title{
THE BRIDE OF THE DESERT
}

a chapter in time

by

\author{
MEGAN HUNTER-WILSON
}

A 120-point thesis

submitted to the Victoria University of Wellington in partial fulfilment of the requirements for the degree of Master of Architecture (Professional)

Victoria University of Wellington

School of Architecture

2018 

To my family and friends whom I have neglected, for their support throughout this five year journey.

To Daniel for his endless enthusiasm and passion for what we do. 
Each night at sunset, the "bride of the desert", as she [the ancient city of Palmyra] has been known for centuries, gets dressed for her wedding. In those last moments of daylight, she dons a robe of stunning colours-the buttery yellow of her limestone columns mixing with the blue shadows of her temples and the soft pinks of the desert floor...

- "Temple of the Bride of the Desert" (Sahner) 


\title{
PREFACE
}

\author{
The following design-led thesis \\ 1 investigation has been conceived and \\ framed as a metaphorical narrative where \\ I build upon an architectural investigation \\ to give something important back to the \\ people of war-ravaged Palmyra: architecture \\ empowered to be seen as a heroine and a \\ guardian - a symbol of hope for rebuilding \\ and for the future.
}

As a speculative work, this project is intended to be experienced through drawing, and to become part of the public realm similar to the way Libeskind and Woods communicate their unbuilt work - presented in an exhibition, visible and accessible to the community. The investigation is not meant to suggest something to be built; but to explore how architecture can be perceived as an architectural guardian watching over the rebuild as a metaphor; architecture to rebuild a community. 

"Is architecture only an end-product that people can physically inhabit, or is it also the matrix of ideas, concepts, and designs that serve as inspirations for constructions that can be inhabited, but lack the financial support, or the technical capacity to be physically built?"

- Lebbeus Woods, Open Questions

"Drawings and models are architecture in their own right. If they are not, I ask, when does the architecture appear?"

- Lebbeus Woods, Open Questions 



\section{ABSTRACT}

$\mathrm{T}$ he Syrian civil war has caused the largest global migration in history, where more than 11 million refugees have been forced to leave their home country due to political conflict. In January 2016 Angela Merkel announced that Syrian war refugees in Europe would be repatriated once the Syrian war is over. But for many Syrians, their homes have been destroyed.

The problem for the returning Syrian people is more than simply providing housing - even more important is how to provide a renewed sense of community as well as cultural and place identity for the returning refugees.

This thesis reflects on how architecture can make a difference in helping to re-establish the cultural and place identity of a war-torn country. The investigation takes a speculative approach to this topic with the principal objective being to provoke discussion and awareness about the fragile future of war-torn historic cities like Palmyra in Syria.

The investigation explores how architectural narrative can be perceived metaphorically as a guardian or a hero sitting within or on the outskirts of a devastated city, watching over it, in a place where it can reflect upon the historic symbolic attributes of the city that once provided its place identity. The Syrian site of this investigation is in Palmyra, and for this site the most important attributes are: the historic Roman ruins to the south (past), the new city being rebuilt in the north (future), the community camel racing track in the west (recreation, freedom) and the Tadmor Prison in the east (imprisonment, restriction). These four sites can be understood as icons of the city's ongoing time line, and acting as catalysts for new development that ensure the continuity of the community's past and future.
The final design proposition is to establish a metaphorical sanctuary for returning Syrian refugees, a place that functions as: 1) a memorial to ensure remembrance of the devastating crisis, 2) an archive of broken cultural artefacts, and 3) a place where returning refugees can come to understand the war as but one chapter in an ongoing cultural heritage that has endured the past and will move forward proudly into the future. This metaphorical sanctuary acts as a 'guardian', meant to greet the refugees upon their return to their homeland. As a sanctuary, they 'inhabit' it while awaiting the rebuilding of their homes - and by inhabiting it, they become a community with others who have suffered devastating loss, others who are determined to remember, and to move forward. This speculative sanctuary design has been conceived to aid them in the essential process of recovery, as an architectural exhibition. Like similar work of Woods and Libeskind, it is buildable architecture, never intended to be built.

Through this memorial/sanctuary, the devastation of war and tragic loss can be reflected upon as one segment of an ongoing eternal time line linked back to their ancient civilization, so that the recent war is not perceived as an ending of their community, but instead as an important reminder of a greater narrative that everyone shares, a narrative that can help define their strength and resilience as they move into the future. 



\section{CONTENTS}

$\begin{array}{ll}\text { iii } & \text { Acknowledgements } \\ \text { v } & \text { Preface } \\ \text { ix } & \text { Abstract }\end{array}$

$\begin{array}{ll}1 & 01 \text { Introduction } \\ 13 & 02 \text { Site Analysis } \\ 45 & 03 \text { Literature Review \& Precedents } \\ 83 & 04 \text { Concept \& Sketch Design } \\ 107 & 05 \text { Preliminary Design } \\ 141 & 06 \text { Developed Design } \\ 195 & 07 \text { Conclusion }\end{array}$

202 Works Cited

206 Figure List 



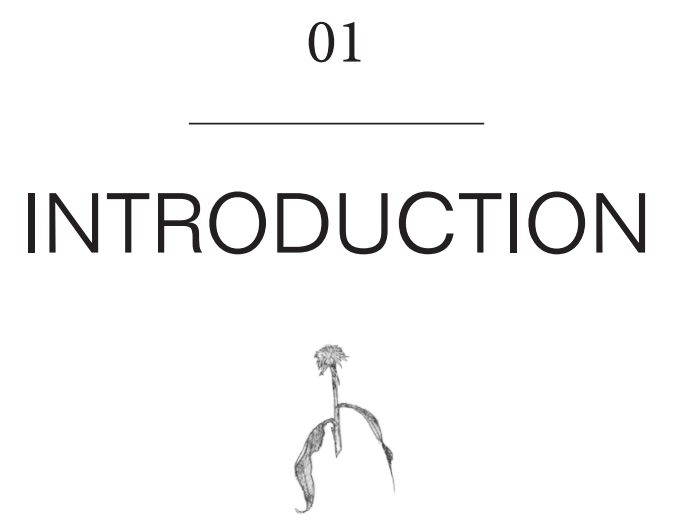


THIS CONTENT IS NOT AVAILABLE

PLEASE REFER TO PHYSICAL COPY

Figure 1. Free Syrian Army (FSA) fighter poses on his horse in grove of olive trees. 
The Syrian civil war has caused the largest than 11 million refugees have been forced to leave their home country due to political conflict. In January 2016 Angela Merkel announced that Syrian war refugees in Europe would be repatriated once the Syrian war is over (Dearden). But for many Syrians, their homes have been destroyed.

The problem for the returning Syrian people is more than simply providing housing - it is also about how to provide a renewed sense of community as well as cultural and place identity for the returning refugees.

This topic is becoming increasingly more important because this is a problem that will be happening soon, but has not happened yet, and architects need to prepare a solution before the crisis occurs. 
THIS CONTENT IS NOT AVAILABLE

PLEASE REFER TO PHYSICAL COPY

Figure 2. An abandoned

home in

Alleppo, Syria. 
The following design-led research help to re-establish returning refugees' awareness and celebration of cultural and place identity within the context of a war-torn country.

The investigation takes a speculative approach to this topic, conceiving architectural design not necessarily intended to be built (though possible to build and inhabit), with the principal objective being to provoke discussion and awareness about the fragile future of a historic city.

\section{refugee}

NOUN

"A person who has been forced to leave their country in order to escape war, persecution, or natural disaster."

- Oxford Dictionary 
THIS CONTENT IS NOT AVAILABLE

PLEASE REFER TO PHYSICAL COPY

Figure 3.

Syrian Army soldier rests amongst the rubble of historic Roman ruins in Palmyra that were destroyed by occupying forces. 


\section{RESEARCH QUESTION: WHAT ROLE CAN ARCHITECTURE PLAY IN HELPING TO RESTORE THE IDENTITY OF A COMMUNITY AFTER A TRAUMATIC DISASTER?}

$\mathrm{O}$ nce such an event has occurred, simply rebuilding the original architecture in its original form would create at best a contemporary 'mask' of sorts pretending to be historic, but in fact a false identity. Rebuilding the city anew, on the other hand, using contemporary architectural ideas might create a vibrant modern city, but the visible time line that establishes true place and cultural identity would be lost. This investigation understands this conflict as fundamental to the challenge of renewal after devastating loss of a built landscape. An appropriate solution to such a crisis requires sensitivity to how the old is retained or remembered, while at the same time the new is born and invited to flourish.
The proposition of this investigation is that the first step for destroyed cities like Palmyra must be to first establish awareness of these issues and their required sensitivities. It proposes that architecture can enhance awareness of these issues and help establish meaningful dialogues about them, before any new building is even built - by first providing a speculative response in the form of narrative drawings and models meant to be viewed in public forums prior to the start of any rebuild.

This thesis presents such a speculative response for the crisis that has befallen Palmyra in Syria, where the war is only now ending - and the fundamental loss of place, cultural, and community identity is about to be felt by the population of returning refugees.

"Is architecture only an end-product that people can physically inhabit, or is it also the matrix of ideas, concepts, and designs that serve as inspirations for constructions that can be inhabited, but lack the financial support, or the technical capacity to be physically built?" 
THIS CONTENT IS NOT AVAILABLE

PLEASE REFER TO PHYSICAL COPY

Figure 4. Road

to Palmyra. 


\section{AIMS \& OBJECTIVES}

$\mathrm{T}$ he Research Aims of this investigation (what it hopes to achieve) are to create an architectural intervention:

- that is explicitly conceived to invoke discourse about an important political, social, and environmental issue.

- that reflects on loss and aids in restoring the identity of a war-torn city.

- that generates a renewed sense of cultural ownership, identity and control in response to the destruction of an historic homeland.
The Research Objectives of this investigation (how it plans to achieve the aims) are:

1. Speculative Architecture: To engage 'speculative architecture' as an approach to invoke discourse and critical reflection about the research problem.

2. Anthropomorphic Architecture: To anthropomorphise an architectural intervention, such that the returning citizens of Palmyra recognise and interpret it as a 'guardian' or 'sentinel' or 'heroine', looking out over their community. Such an intervention can represent the guardian of a community's history and heritage, pointing inhabitants in the directions of important heritage points in the community's time line.

3. Narrative Architecture: To establish an architectural narrative through which the architectural intervention can provide hope to its inhabitants, as well as a renewed sense of the devastating loss being but one chapter in an ongoing time line that has a proud past and a vibrant future ahead.

4. Contextual Architecture: To invite the materiality of the context to become a major component of the architectural response, thus ensuring that the original context is understood as an essential component of place identity - a place identity component that has withstood the devastation despite the appearance of total loss.

5. Habitable 'Sculpture' as Architecture: To invite a speculative, anthropomorphised, narrative - 'sculptural' - intervention to be translated into habitable architecture, representing a 'sanctuary' for newly returning refugees, as well as a 'memorial' for the community once it has found its footing once more. 

In the following chapters these objectives will be achieved through the analysis of theory and precedents:

1. To achieve the first Research Objective, to invoke discourse and critical reflection through speculative architecture, the work of Lebbeus Woods will be investigated.

2. To achieve the second Research Objective, to anthropomorphise an architectural Intervention, the work of Lynn Chadwick will be investigated.

3. To achieve the third Research Objective, to convey a meaningful narrative, the work of Daniel Libeskind will be investigated.

4. To achieve the fourth Research Objective, to integrate the materiality of the architecture and its context, the work of Mary Miss will be investigated.

5. To achieve the fifth Research Objective, to translate a speculative, anthropomorphised, narrative intervention into habitable architecture, the work of Walter Pichler will be investigated. 
Figure 5.

Bullet-riddled

rooms in

Quneitra, Syria

THIS CONTENT IS NOT AVAILABLE

PLEASE REFER TO PHYSICAL COPY

Figure 6. A

Bedouin's

donkey,

outside of

Palmyra.

THIS CONTENT IS NOT AVAILABLE

PLEASE REFER TO PHYSICAL COPY 


\section{METHOD}

$\mathrm{T}$ he design methodology follows an iterative and experimental process that begins with the research of site, and then aligns its research aims and objectives with the theoretical work of Lebbeus Woods, Daniel Libeskind, Mary Miss, Lynn Chadwick and Walter Pichler. Through this alignment, a strategic set of design principles was produced to begin the design experiments. The design experiments are an iterative process, starting siteless and in the end becoming deeply connected within the context. The method is very process driven, and is sculpted by critical analysis of each stage.

\section{SCOPE}

This thesis fundamentally deals with providing returning refugees with a safe place, a metaphorical sanctuary, when they return home to Palmyra after the war. The intention of this metaphorical, speculative approach is to create awareness about the serious problem of refugees returning to a destroyed home.

The scope for this investigation is limited to design investigations that are focused on combining elements required to live with the contextual elements of site so the building becomes a cohesive didactic experience for the user, restoring hope and enhancing strength and resilience in the community.

The intention of this project is speculative and to be experienced through drawing and modelling. The built intention would take away from the importance of the problem at hand and would introduce additional critical variables that would change the final design.

The structure of the following chapters begins with the analysis of site to establish a strategic set of design principles that can be incorporated into the design experiments. Theoretical approaches are then analysed to strengthen and build a cohesive argument for the design response. The design process is then presented through five phases that begin with early concept experiments and develop through to resolved preliminary designs that are critically reflected against the aims and objectives. Then follows the final design experiment which is expressed through drawing, sculpture and architecture to establish a metaphorical 'sanctuary' that a community 'metaphorically inhabit' whilst awaiting the construction of new housing after their return to a devastated community. 

02

SITE ANALYSIS<smiles>CCCCCCCCCCCC</smiles> 
THIS CONTENT IS NOT AVAILABLE

PLEASE REFER TO PHYSICAL COPY

Figure 7.

Three-part panorama of Palmyra taken from the historic ruins of Diocletian. 
This chapter establishes a strategic set of

1 contextual design parameters that can be incorporated into the design experiments. It will present an overall history of the site and culture of Palmyra, then further define specific site elements that will become the contextual design parameters that are used in the final design.

The inclusion of this analysis is integral to the investigation as it is the identification of historic, cultural and identity elements mentioned in the aims and objectives that will be used to create an appropriate design response.

Overall, the chapter provides the specific elements required to be able to arrive at a response that embodies the contextual cultural past. It will identify what the city once was, what it is today, and what it could be in the future. 
THIS CONTENT IS NOT AVAILABLE

PLEASE REFER TO PHYSICAL COPY

Figure 8.

Syrian Army

soldiers climb

on ruins of the

Temple of Bel. 
The chosen site for this investigation is a

1 historic town in the middle of the harsh Syrian Desert called Palmyra.

This site has an extremely rich cultural past with both a historic and torn urban landscape, and provides the opportunity to envisage a hopeful future.

The Syrian war has been devastating to Palmyra, and now there is the need for an architectural intervention to provide refugees with a new sense of cultural ownership,

identity and control when the war is over and they return home to Palmyra in a broken and devastated state. 


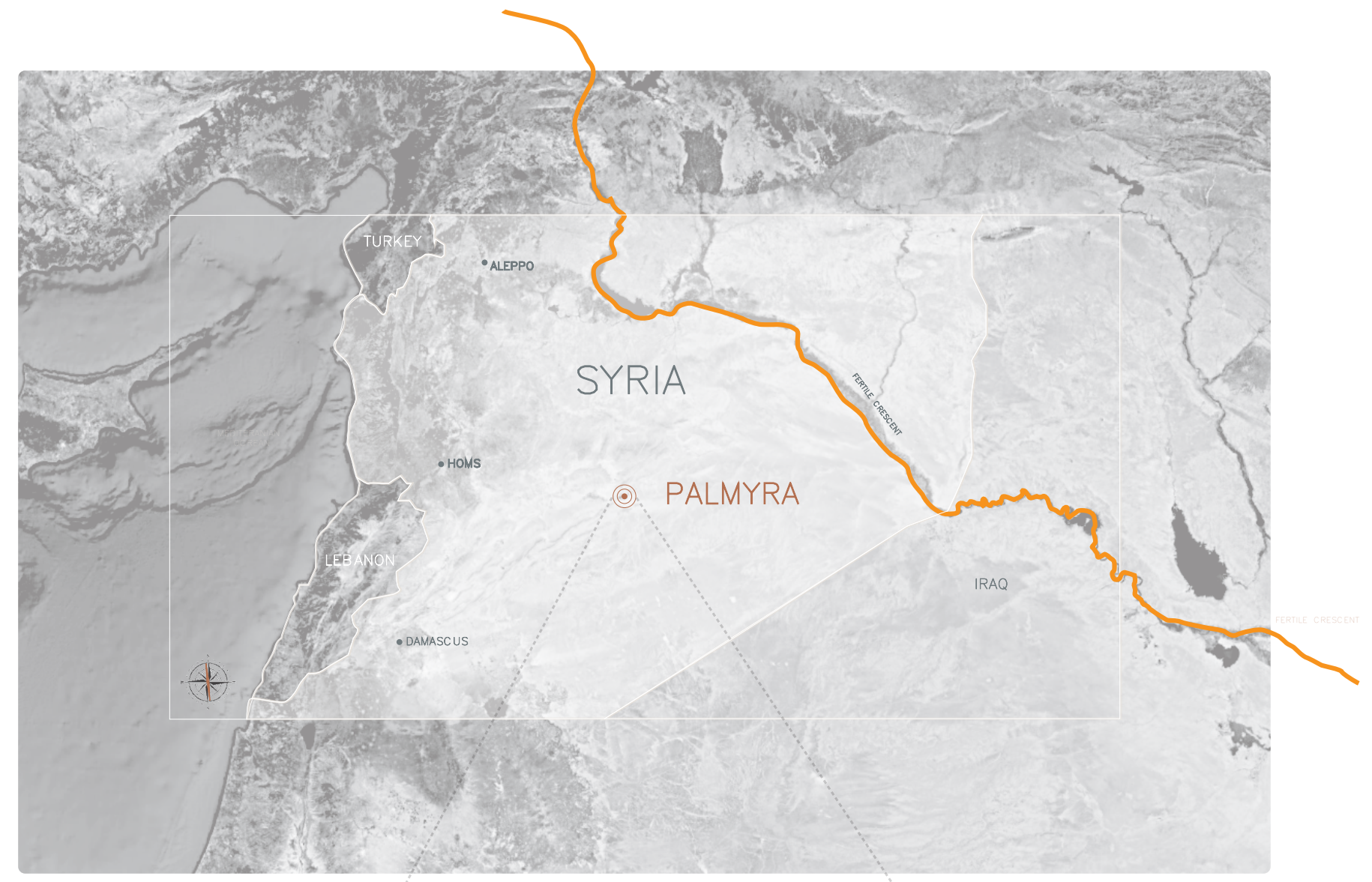

18

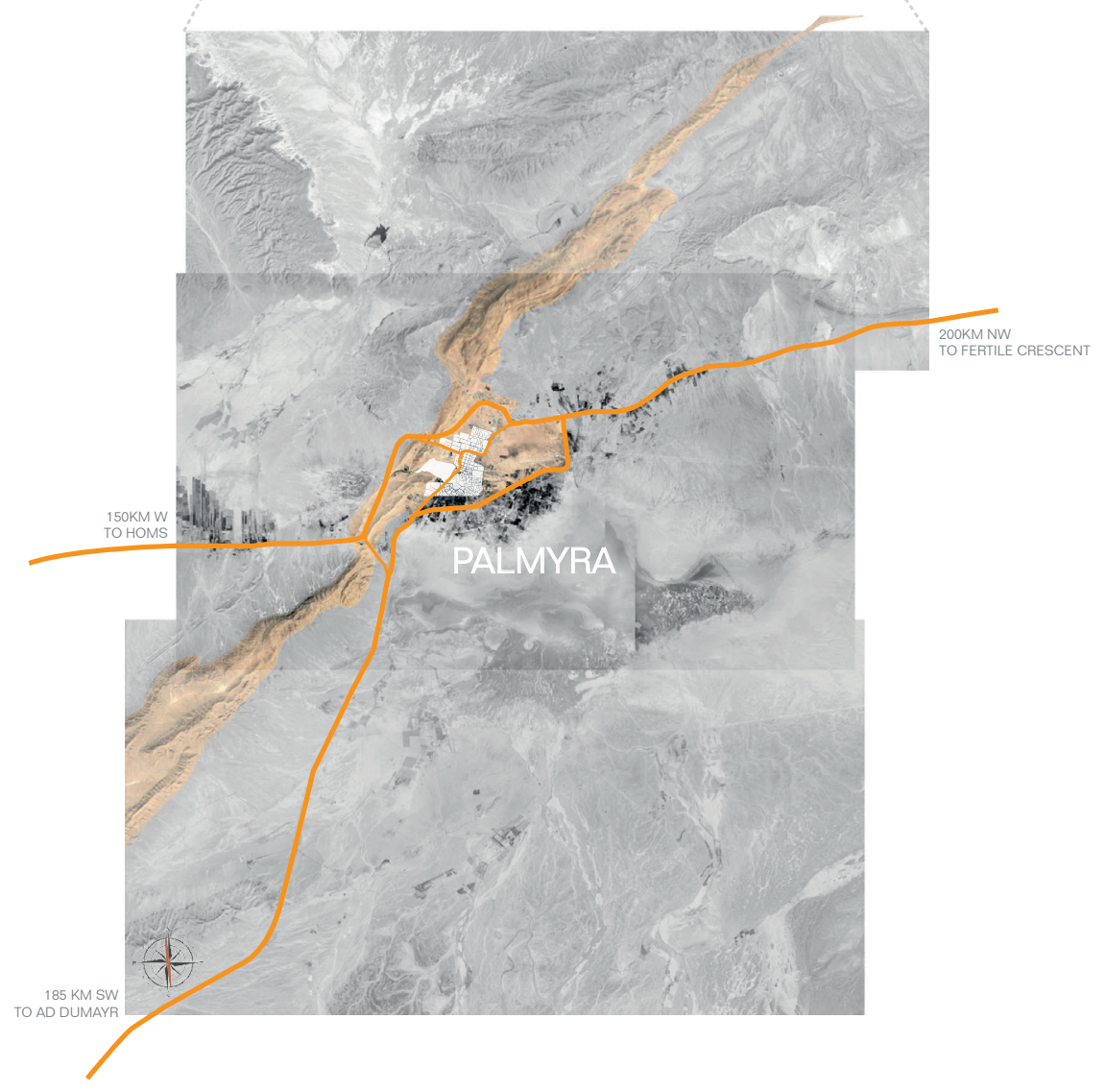

Figure 9.

Location of

Palmyra in

Syria. 
Tn the middle of the Syrian Desert, Palmyra

1 is a landlocked city situated on a flat desert plain surrounded by mountains and further flat expanses. It is very isolated, located 130 miles northeast of Damascus.

The first settlers were attracted to this location because of the underground water supply that feeds an oasis, which provides water for the people and agriculture, and allows rich orchards of date, olive and pomegranate crops to grow (Burns, 206). 
THIS CONTENT IS NOT AVAILABLE

PLEASE REFER TO PHYSICAL COPY

Figure 11. The ancient Roman ruins south of Palmyra,

looking down

the main

colonnaded

street to the

Temple of Bel.

THIS CONTENT IS NOT AVAILABLE

PLEASE REFER TO PHYSICAL COPY

Figure 12. 
B efore the Syrian war began Palmyra was

B home to more than 30,000 Palmyrenes, and over 100,000 tourists would visit the ancient city - a UNESCO World Heritage Site

(Figure 11) - every year (Burns, Iain).

In 2015 when ISIS took control of the city, the extremist group destroyed many of the ancient buildings in the historic district, as well as major infrastructure, houses and public buildings in the modern city (figure 12)

(Burns, Iain).

It is this damage and destruction caused by the war that has created the problem to which this design-led research investigation responds. 


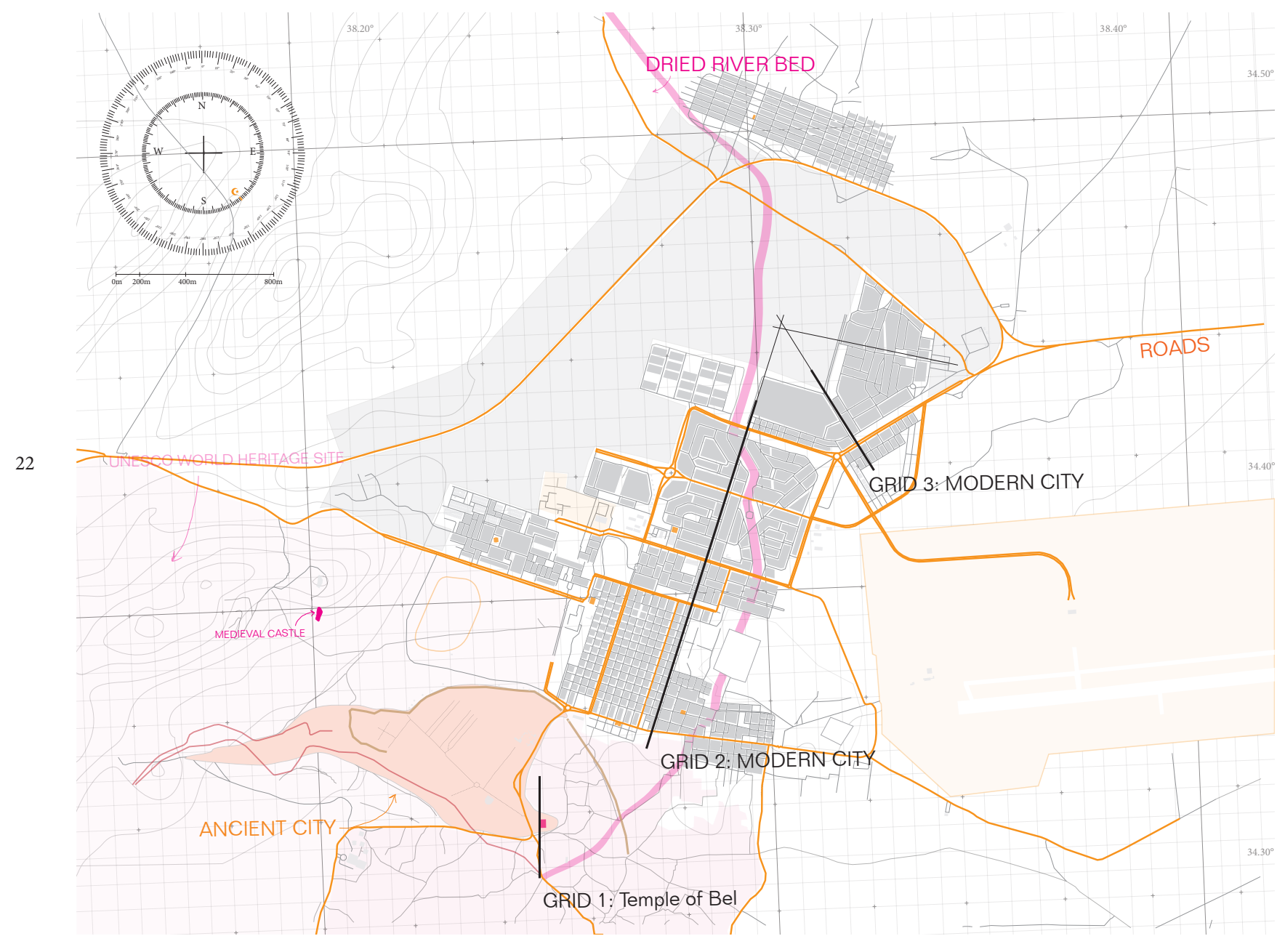

Figure 13.

Diagrammatic

map of

Palmyra

showing grids

and road

layout. 
he city map (figure 13) shows a series of fluid lines (defined by roads and created by natural contours) in combination with two main orthogonal shifted grids (black lines), and how they intersect on a northern site, indicating the exact location of site selected for the final design intervention. As well as being located at the apex of these shifting geometries, this site is also located in the predicted direction of expansion and future urban growth (grey shaded area Figure 13) (Kain, 17).

The winding orange lines show main roads that carve through Palmyra. The modern city was built after the ancient city and this map shows the contrast between structured, grid-like roads that run through the modern city, versus the soft weaving of the roads that enter and leave the city from the north and the south, outlining the UNESCO World Heritage Site (shaded pink in figure 13). Another important fluid geometry is the dried river bed which the underground water source would flow down, underneath the modern city (thick pink line figure 13). 
Figure 14

Etching of the ancient city of Palmyra during the

Roman

occupation

THIS CONTENT IS NOT AVAILABLE

by George

Middle section

PLEASE REFER TO PHYSICAL COPY

of Colonnade

Street, ca. 1799

THIS CONTENT IS NOT AVAILABLE

PLEASE REFER TO PHYSICAL COPY

Figure 15.

Etching of the ancient city of Palmyra during the

Roman

occupation by Claude Niquet. Funerary

Temple, ca. 1799 


\section{PALMYRA}

The narrative

$\mathrm{T}$ he first settlers to arrive in Palmyra in the third millennium $\mathrm{BC}$ were attracted to the oasis spring located in the south of the city where date, olive and pomegranate crops are still grown today (Stoneman, 94). It was rare for water to be found in the middle of the vast desert, and so this site became a perfect location to start a city and provide a place for travellers to stop on their journey through the desert (Burns, 206).

Palmyra gained the majority of its wealth in the Second Century when it became a major node on the Silk Road trade route which linked the Han Empire in the East with the Roman Empire in the West. It was the trading role of Palmyra that allowed the city to flourish, and brought the construction of the Temple of Bel in the late first century (Figure 27). The Temple of Bel was later used as a caravanserai - an important sanctuary which provided a safe place to stay for the travellers and their belongings. This notion of the caravanserai is explained further in this chapter (page 40) as it becomes very important element in the design investigation.
Palmyra has had many rulers throughout its history. The first, Hadrian in 129 BC, led the city at the beginning of its rise. The Second Century marked the peak of the city's success due to trade, which brought in money, leading to the construction of many civic buildings with Roman vernacular (Burns, 207).

In the Third Century, after the Parinthian wars in 160 BC, the Roman Emperor Caracalla declared Palmyra a part of the Roman Colony, which led to the rapid decline in travellers and trade due to decline in political stability. There were political uprisings, wars, death, violence, which greatly affected trade across land. The Roman Empire diminished and so did Palmyra. However, it was still fought over by various Roman rulers such as Odenathus in $250 \mathrm{AD}$ to Aurelian and Zenobia in 270 and later Justinian in 520, leading to the destruction of the city and its grand early Roman architecture (Burns 208, 209).

To be able to create an appropriate design solution within the layers of this story it was important to understand the history and identity of this illustrious culture and place. This narrative enables the understanding and presents the lengthy time line of wars and violence that has caused the ancient city to crumble over time, while always finding ways to repair and flourish once more. 


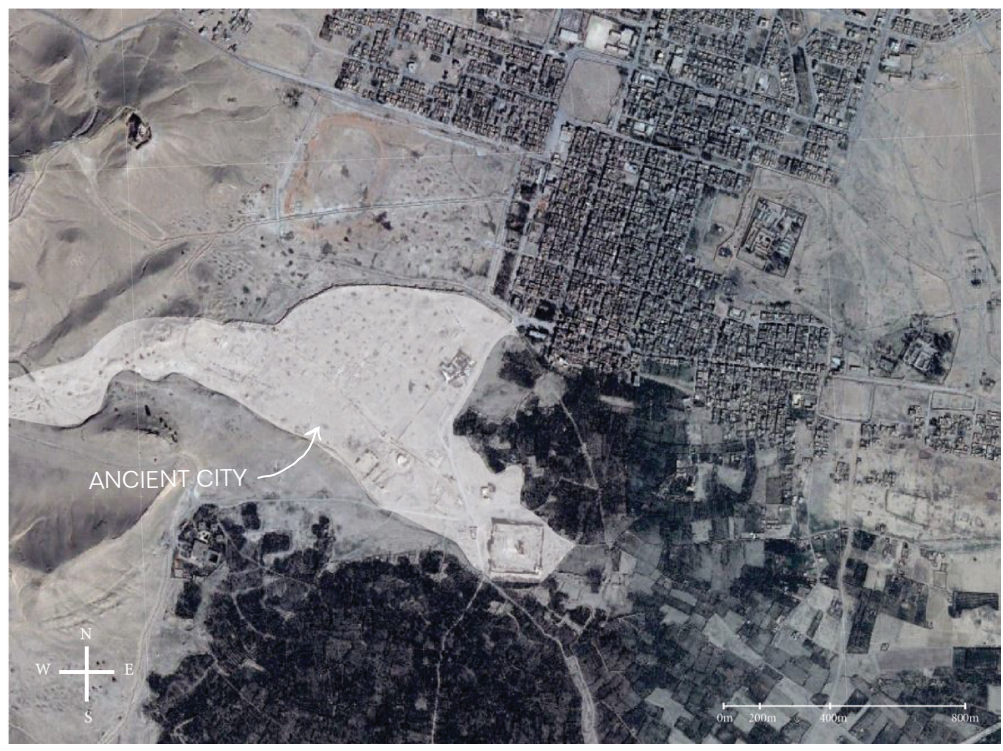

Figure 16.

Map showing

the location

of ancient

ruins south of

Palmyra.

Figure 17. 3D view looking

southeast

over the

Ancient City,

palmery in the background. 
THIS CONTENT IS NOT AVAILABLE

PLEASE REFER TO PHYSICAL COPY

Figure 18.

Syrian Army

soldiers take shade beneath some of the huge pillars in the Temple of Bel which survived Islamic State efforts to destroy the ruin.

The ancient Roman Temple of Bel, situated 1 at the south (far) of the city (Figure 17), is connected to the end of a dramatic colonnaded street that connects other elements of the ancient Roman town such as the amphitheatre and the marketplace and also leads to the temple tombs that sprawl into the valleys beyond. This long colonnaded street in the centre of the ancient city provided a very dramatic entrance for foreigners arriving in the city.

Figure 18 shows human scale at the base of the massive pillars in the colonnaded ancient Roman street. Upon regaining control of Palmyra in March 2017, Syrian Army soldiers were the first to re-enter the city and check for damage made by ISIS. 
Figure 19.

Syrian Army soldiers take shade

beneath some of the huge pillars in the Temple of Bel which survived Islamic State efforts to destroy the ruin.

The pillars that lined the central street tall, informing verticality in later design experiments; Figure 19 shows human scale. 
Figure 20

Syrian Army

soldiers

climb

through the

ruins of the

Temple of

Bel, reduced

to rubble

after being

bombed by

Islamic State

militants.

THIS CONTENT IS NOT AVAILABLE

PLEASE REFER TO PHYSICAL COPY

The Temple of Bel was at the end of this colonnaded street, and was mainly destroyed under control of ISIS, with only the arch remaining. Figure 20 shows the destruction and remaining rubble that returning refugees will be faced with upon returning. 
Figure 21 .

Retreating

Islamic State

militants laid

mines under

the main

roads in

Palmyra at

50-metre

intervals, in

an attempt to

cause further

Army losses.

THIS CONTENT IS NOT AVAILABLE

PLEASE REFER TO PHYSICAL COPY

ther destruction of the city includes one of the main roads into Palmyra, which has been torn to shreds by land mines and grenades (Figure 21). One role of the soldiers was to check the city for hidden mines so residents can safely return. 
Figure 22

Much of

modern

Palmyra lies

in ruins, from

fierce

fighting

between the

Syrian Army

and the

Islamic State,

which

controlled

the city for

ten months,

as well as

from the arial

bombardmen

ts carried out

by the

Russian Air

Force.

\section{THIS CONTENT IS NOT AVAILABLE}

PLEASE REFER TO PHYSICAL COPY

Houses and public buildings were destroyed by the fighting. Figure 22 shows one example of a ruined house that Palmyrenes will return to. 
Figure 23.

The tarmac

of the road

leading into

Palmyra city

centre is torn

open by

mines laid at

50-metre

intervals by

retreating

Islamic State

militants, in

an attempt to

cause further

THIS CONTENT IS NOT AVAILABLE

Army losses.

PLEASE REFER TO PHYSICAL COPY

nother main road looking out from the $\mathrm{Imodern}_{\text {town, and up to the Medieval }}$ castle (located on map in Figure 13) on a western hill, a witness to the devastation. The road has been torn up by land mines and grenades. 
THIS CONTENT IS NOT AVAILABLE

PLEASE REFER TO PHYSICAL COPY

Figure 24.

Syrian Army generals and soldiers gaze over Palmyra from the medieval citadel. Gaining control of the strategic citadel was a decisive moment in the battle for Palmyra.
Soldiers rest, looking east across the smoking remains of the broken city. 


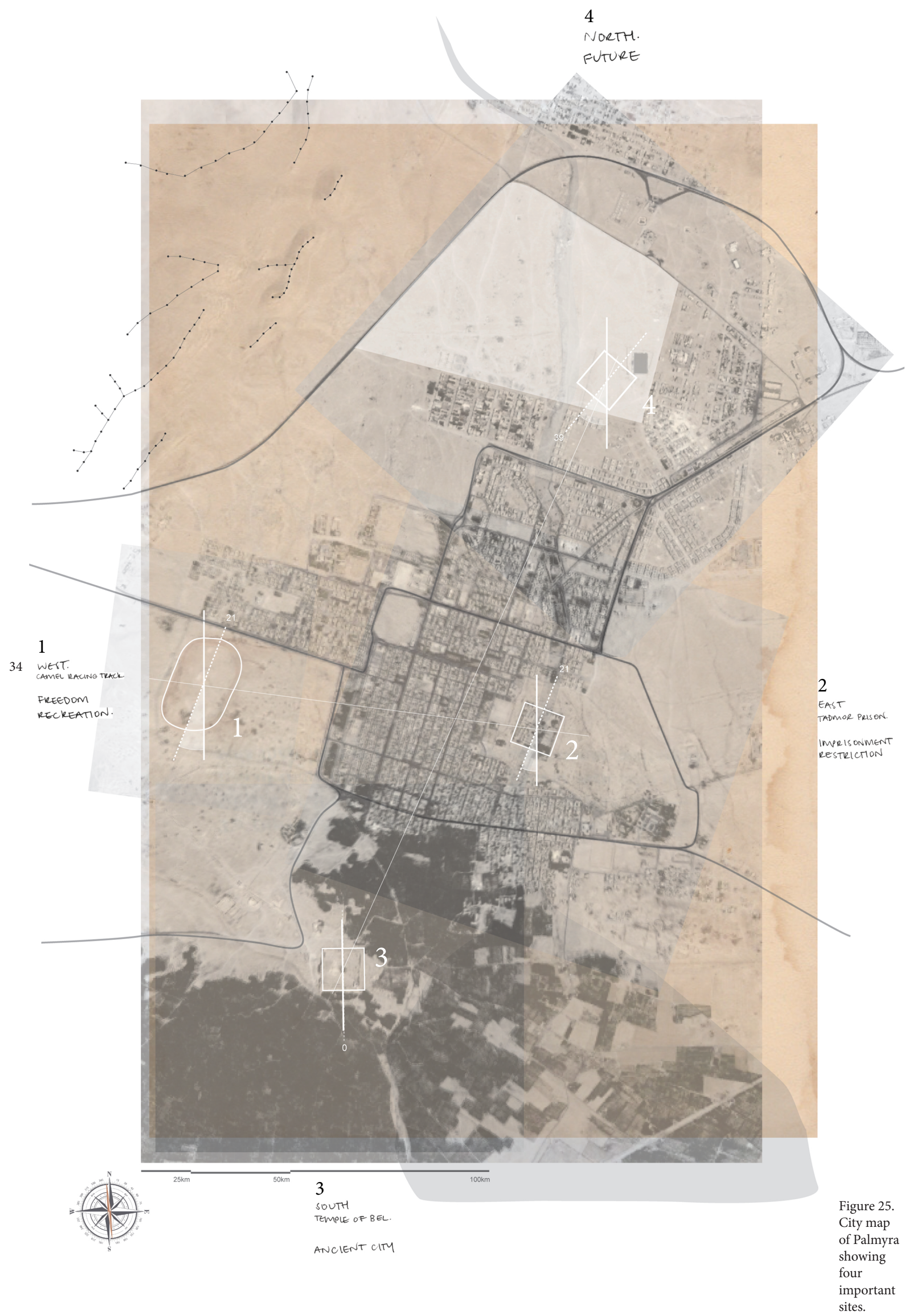


7 he following pages highlight three sites 1 that contain important identity attributes of Palmyra. The three sites are later used as metaphors to inform design decisions for the preliminary experiments and final design. Figure 25 shows the location of each, and relation to the others and the city.

The fourth important site shown in this sequence is located in the north, and is the chosen site for the final design experiment. As this location was chosen because according to the Palmyra Regional Action Strategic Plan future development will occur in this northern location (Kain, 11). The second main reason for choosing this site location is because it is the apex of three urban grids as shown earlier (figure 13). 


\section{WEST \\ CAMEL RACING TRACK}

The camel track represents the opposite of Tadmor Prison: recreation and freedom, sport and community. The camel track is a place where everyone is equal; respect and fondness is shared nationally for the animals and the sport. 


\section{EAST \\ TADMOR PRISON}

The Tadmor Prison represents harsh conditions, extensive human rights abuse, torture and execution of political activists. It is one of the most notorious prisons in the world for the inhumane treatment of inmates, most of whom are political prisoners.

Figure 27.

Tadmor Prison

THIS CONTENT IS NOT AVAILABLE

PLEASE REFER TO PHYSICAL COPY 


\section{SOUTH TEMPLE OF BEL}

The third quadrant holds the Temple of Bel, the largest and most sacred structure in the ancient city. This quadrant represents the rich history of Palmyra as it holds the origins of identity, trade and wealth, violence and war. The Temple of Bel was once a Caravanserai and was the centre point for the ancient community (Burns).

THIS CONTENT IS NOT AVAILABLE

PLEASE REFER TO PHYSICAL COPY

Figure 28.

Temple of Bel 


\section{NORTH CHOSEN SITE}

The chosen site makes up the fourth quadrant, and represents the future of Palmyra. It is the catalyst for change in the urban plan and it sits at the intersection for three urban grids (Kain, 17). 
CARAVANSERAI

THIS CONTENT IS NOT AVAILABLE

PLEASE REFER TO PHYSICAL COPY

Figure 30.

Exterior view

of caravanserai in vast desert.

\footnotetext{
The caravanserai is an important cultural element in middle eastern culture that is referenced in the final design. Also known as "desert palaces" they are important because they acted as sanctuaries which were dotted along long trade routes throughout deserts in the Middle East to provide shelter for travellers, their belongings and their animals (Schutyser, Intro). They were a place where foreigners and locals were safe and protected along harsh isolated roads.
} 


\section{TEMPLE OF BEL}

Figure 31

Temple Of Bel

Floor Plan

THIS CONTENT IS NOT AVAILABLE

PLEASE REFER TO PHYSICAL COPY

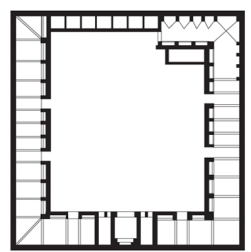

Figure 32.

Typical

floor plans

of various

caravanserai.
The Temple of Bel was constructed in GrecoRoman style on a north-south axis; it consisted of a paved court with a large columns that spanned 205 meters around the perimeter (Gates, 390). Although in the centre of this court was a Roman temple (later used as a mosque), the caravanserai element was created around the perimeter of the court where mud huts were built in the open for travellers to inhabit (Terpak). This presents an interesting contrast between different historic materials representing the permanent stone and temporality of the mud - a language that is used later in the design.

\section{SPATIAL ARRANGEMENT}

Figure 32 shows typical floor plans of four caravanserai. They were generally arranged with a communal uncovered courtyard in the centre, and various spaces around the outside which were used as sleeping chambers - this was also a dialogue that is used later in the design stage.

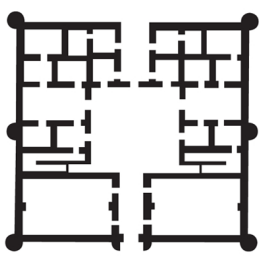



This chapter has established a strategic set be incorporated into the design experiments. These design parameters include: the converging of orthogonal, skewed, and fluid grids, fertility provided by the oasis spring, three historic identity sites of the prison, camel track and ancient city, and the notion of the caravanserai.

All of these elements represent place and cultural identity for the Palmyrene people, and as such have been incorporated into design experiments and then developed within the final design experiment. The following chapter will further build upon this argument by exploring relevant theoretical implications of this research through the investigation of 5 theorists and related precedents. 

03

\section{LITERATURE REVIEW \& CASE STUDIES}




his chapter explores selected theoretical
approaches that relate to specific aims and objectives of this thesis and help to strengthen the design response to the research problem.

The precedent studies aim to represent design approaches to resolving the research problem, as well as interpreting the theoretical approaches from literature and addressing the Research Objectives

Specifically this chapter looks in detail at how theorists achieve the research objectives of this investigation; these research objectives are:

1. Speculative Architecture to invoke discourse and critical reflection about the research problem;

Lebbeus Woods

2. Anthropomorphic Architecture to enable the intervention to be interpreted as a 'guardian' or 'heroine' by the citizen; Lynn Chadwick

3. Narrative Architecture to establish an architectural narrative that provides hope for the future;

Daniel Libeskind

4. Contextual Architecture to invite materiality of the context to become a major component of the response;

Mary Miss

5. Habitable 'Sculpture' as Architecture to invite a speculative, anthropomorphized, narrative 'sculptural' intervention to be translated into habitable architecture; Walter Pichler 



\section{LEBBEUS WOODS}

1940 - 2012

THIS CONTENT IS NOT AVAILABLE 
THIS CONTENT IS NOT AVAILABLE

PLEASE REFER TO PHYSICAL COPY

Figure 34.

Photon Kite,

from the series

"Centricity,"

1988. Graphite

on paper. 
Tebbeus Woods was the most

Linfluential theorist at the beginning of this investigation, when the research was strongly situated around post-war architecture and making an important statement about the research problem through an unbuilt scheme.

"What if we lived by a different set of rules, ones that didn't have, for example, governing agencies that dictate how buildings could stand up or not, or even gravity and physical limitations that dictate the specific kind of architecture we must live with?"

- Woods (Anderson) 
THE ZAGREB FREEZONE

1990

Figure 35.

Case Study:

Zagreb Free

Zone

THIS CONTENT IS NOT AVAILABLE

PLEASE REFER TO PHYSICAL COPY

THE BERLIN FREEZONE 1991

THIS CONTENT IS NOT AVAILABLE

PLEASE REFER TO PHYSICAL COPY

Figure 36. Case Study: Berlin Free Zone 
The 'Zagreb Freezone' and the 'Berlin

I Freezone' are both case studies by Lebbeus Woods and are examples of the radical nature of his theory in design, and were obviously never intended to be built. They are incredibly powerful through the message they send; to shun political, cultural and social norms through the rejection of traditional form that surrounds them and translate the vernacular into a new form that is "heterarchial" (Woods, Anarchitecture, Intro).

He is making a fundamental statement about war through these projects, about a problem, about the crisis people face in a dense urban context and how architecture designed in a certain way can make people conscious of a certain issue.

For this investigation the intervention is located on the edge of the desert, unlike Woods whose is in a urban city centre. His interventions are active participants where the final intervention for this investigation is to be an 'observer'.

The overall goal for these projects is for them to be visualised in a public setting, a website, gallery or journal, to make a statement that architecture can transcend important issues and enable people to generate a greater sense of community, cultural and place identity within the context of a devastation where place has been lost.

There is no way one building could solve the refugee crisis in Syria. For a thesis to attempt to do so with a real building makes no sense. Whereas a thesis looking at the speculative opportunities after a disaster, like Lebbeus Woods did, would enable the investigation to make a statement that might affect people and help to raise awareness of issues that are important. This is what I want my architecture to do. 



\section{LYNN CHADWICK}

$1914-2003$

THIS CONTENT IS NOT AVAILABLE

PLEASE REFER TO PHYSICAL COPY

Figure 37

Lynn

Chadwick in

his studio,

1950 
THIS CONTENT IS NOT AVAILABLE

PLEASE REFER TO PHYSICAL COPY

Figure 38.

Drawings for sculpture. 
Chadwick was one of the most notable British sculptors of his generation, known mostly for his bronze and steel creations that were forms of abstract and expressive anthropomorphic figures (Bird).

He was used as a theorist and his work as a case study for this investigation because he tries to establish abstract forms that are not simply mute, but rather he gives them a sense of presence. He anthropomorphises them and by doing so he makes them confront us. He puts them into a dialogue with us and makes them feel as though they are understood by us by creating a discourse and familiarity. 


\section{CONJUNCTION \\ 1953}

THIS CONTENT IS NOT AVAILABLE

PLEASE REFER TO PHYSICAL COPY

Figure 39.

\footnotetext{
Conjunction (Figure 39) and Conjunction V $\cup$ (Figure 40) both by Chadwick evidence his theories as the forms depict anthropomorphised elements and abstractions that an architect can look at and start to realise translation opportunities. These case studies both show clear sense of a entry, a gateway, a portal. A clear sense of shelter with a roofed opening, a clear sense of habitable volume up above. Whilst they are definitely not architectural, they begin to allow themselves to be translated into architecture.
} 


\section{CONJUNCTION V \\ 1958}

THIS CONTENT IS NOT AVAILABLE

PLEASE REFER TO PHYSICAL COPY

Figure 40.

Conjunction V,

1958.

His theories and works were the most influential in the final stages of my investigation where physical and formal elements were required to translate my own ideas from abstract sculpture to an architectural solution to create a similar language that lies on the edge of architecture and sculpture. 

DANIEL LIBESKIND

THIS CONTENT IS NOT AVAILABLE

PLEASE REFER TO PHYSICAL COPY

Figure 41

Daniel

Libeskind 
Case Study: Berlin

"City Edge" Competition PLEASE REFER TO PHYSICAL COPY 
aniel Libeskind, similar to Lebbeus Woods, places his intervention against a context against an urban site. He also works with issues and metaphors about time, balance, scale and symbolism which is how he conveys a narrative, a story, a dialogue.

His designs make a statement both architecturally and socially in order to prolong the memory of a historic event for future generations to look back upon and learn from. 
THE BERLIN “CITY EDGE” COMPETITION 1987

Figure 43.

Berlin "City

Edge" Model.

THIS CONTENT IS NOT AVAILABLE

PLEASE REFER TO PHYSICAL COPY

Figure 44.

Berlin "City

Edge" urban conception.

THIS CONTENT IS NOT AVAILABLE

PLEASE REFER TO PHYSICAL COPY 


\begin{abstract}
$A \mathrm{n}$ example of this is the Berlin City Edge $A_{\text {competition entry by Libeskind in } 1987 .}$ He tells the story using a symbolic narrative of a balance beam that balances on the fulcrum of the Berlin Wall. One half of the beam secured and grounded and accessible in the West, and in the East the other end of the beam hovers above, looking down, never able to enter which creates a very clear simple story told through the symbolism of architectural form resting on its context.
\end{abstract}

The way Libeskind has responded to context through symbols and forms in this project shows that a story does not come from a single static line. It has to be about a balance, about a duality and a responsiveness. For this design led investigation the three historic sites identified in Palmyra can use this notion of narrative to create an intervention that responds to a trilogy of symbols to depict the story through three sentinels that tell the narrative of Palmyra. 

MARY MISS

THIS CONTENT IS NOT AVAILABLE

PLEASE REFER TO PHYSICAL COPY

Figure 45.

Mary Miss 
THIS CONTENT IS NOT AVAILABLE

PLEASE REFER TO PHYSICAL COPY

Figure 46. Case Study: Veiled Landscape, 1979 


\begin{abstract}
ary Miss is an installation artist who employs architectural vocabulary in her work. She deals with connections between built form and the natural environment, and most importantly the blending between the two.
\end{abstract}

One of the biggest obstacles I found in my experimentations was that with the desire to achieve what Woods had achieved, he had used non-traditional architectural forms and there needs to be a fine line between something looking completely alien in a landscape versus something feeling like it is abstracted. Something that is non-traditional, but still arises directly from the landscape. Mary Miss is an example of an architect and a sculptor whom begins to challenge the boundary between the two.

The Veiled Landscape (figure 46) is an installation in the dense forest and expresses the notion of the trees as columns and as the vertical constructs of an architecture. Then the wooden trellis begins to merge with the trees so you become unsure of which one is the architecture and which one is the context, because ultimately when you look through this piece you realise that the context is visually the inhabitant of the architecture. 


\title{
PERIMETERS/PAVILIONS/DECOYS
}

1977-78

\author{
Figure 47. \\ Case Study: \\ Perimeters/ \\ Pavilions/ \\ Decoys \\ 1977-1978
}

THIS CONTENT IS NOT AVAILABLE

PLEASE REFER TO PHYSICAL COPY

\begin{abstract}
A second case study Perimeters/Pavilions/ ADecoys by Miss was completed in 1978. The site on which these interventions sit becomes one of the most fundamental elements of the architecture. The architecture would not exist without the site, the landscape becomes the walls, which are the most critical elements.
\end{abstract}

In the final design for this thesis, the context is invited to inhabit the architecture, you are invited to see through the architecture to the context and vice versa. The boundaries will begin to be merged between built and unbuilt, and show how the two need one another in order to have a definition, and to express the narrative that they are describing. 
Figure 48

Case Study:

Perimeters/

Pavilions/

Decoys

1977-1978
THIS CONTENT IS NOT AVAILABLE 

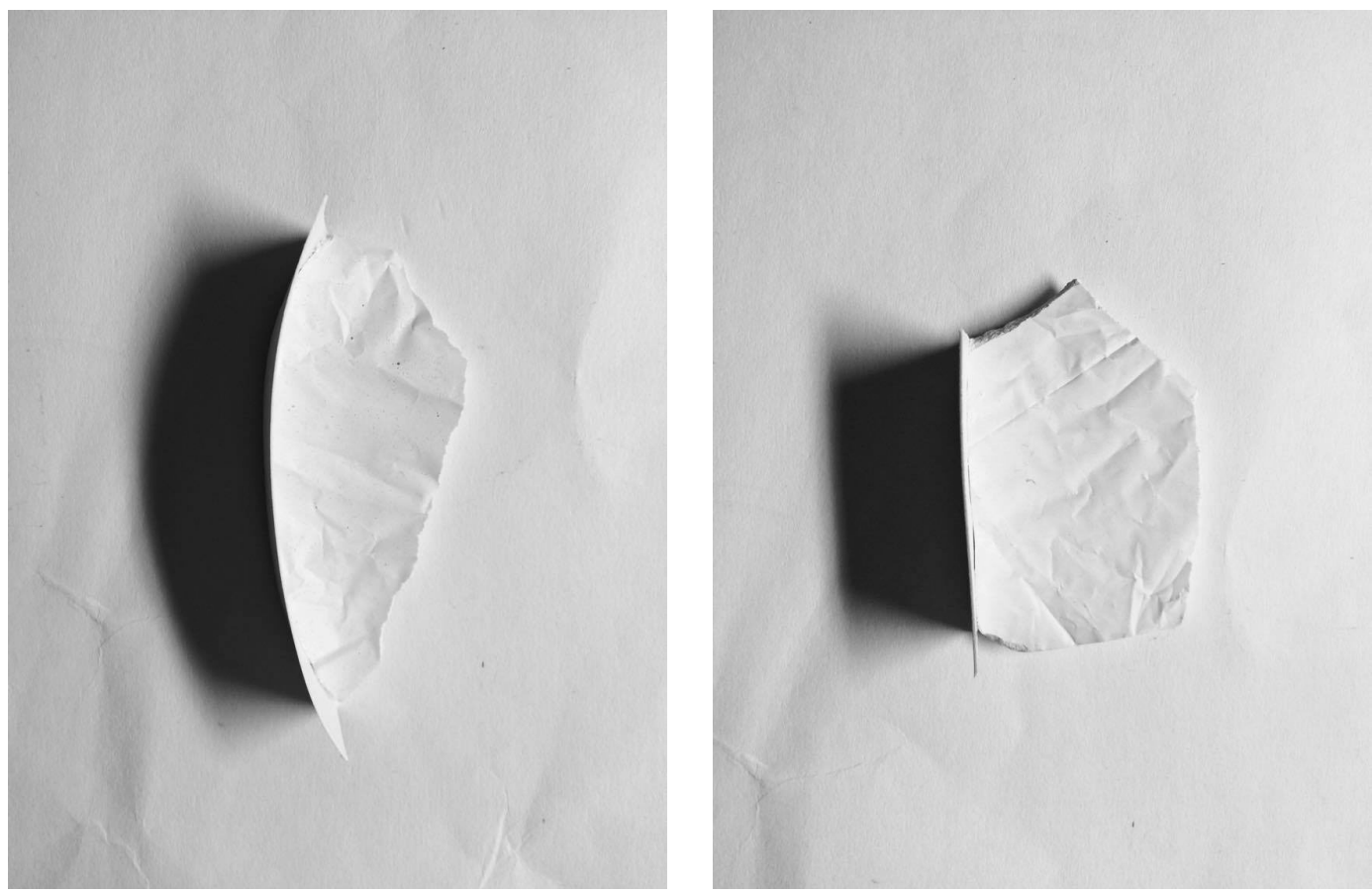

Figure 49 .

Authors

work. Plaster

and card

experiment
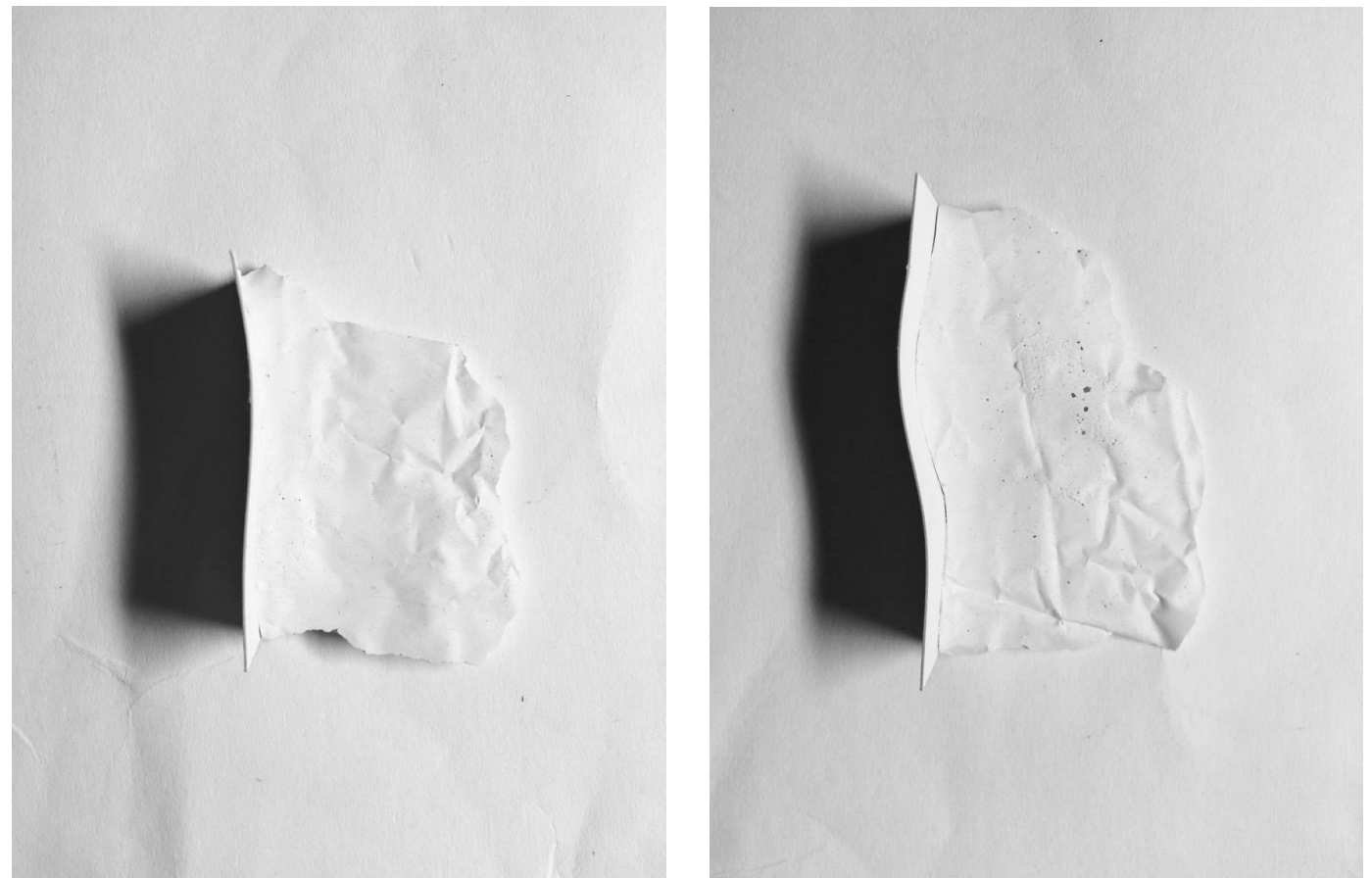

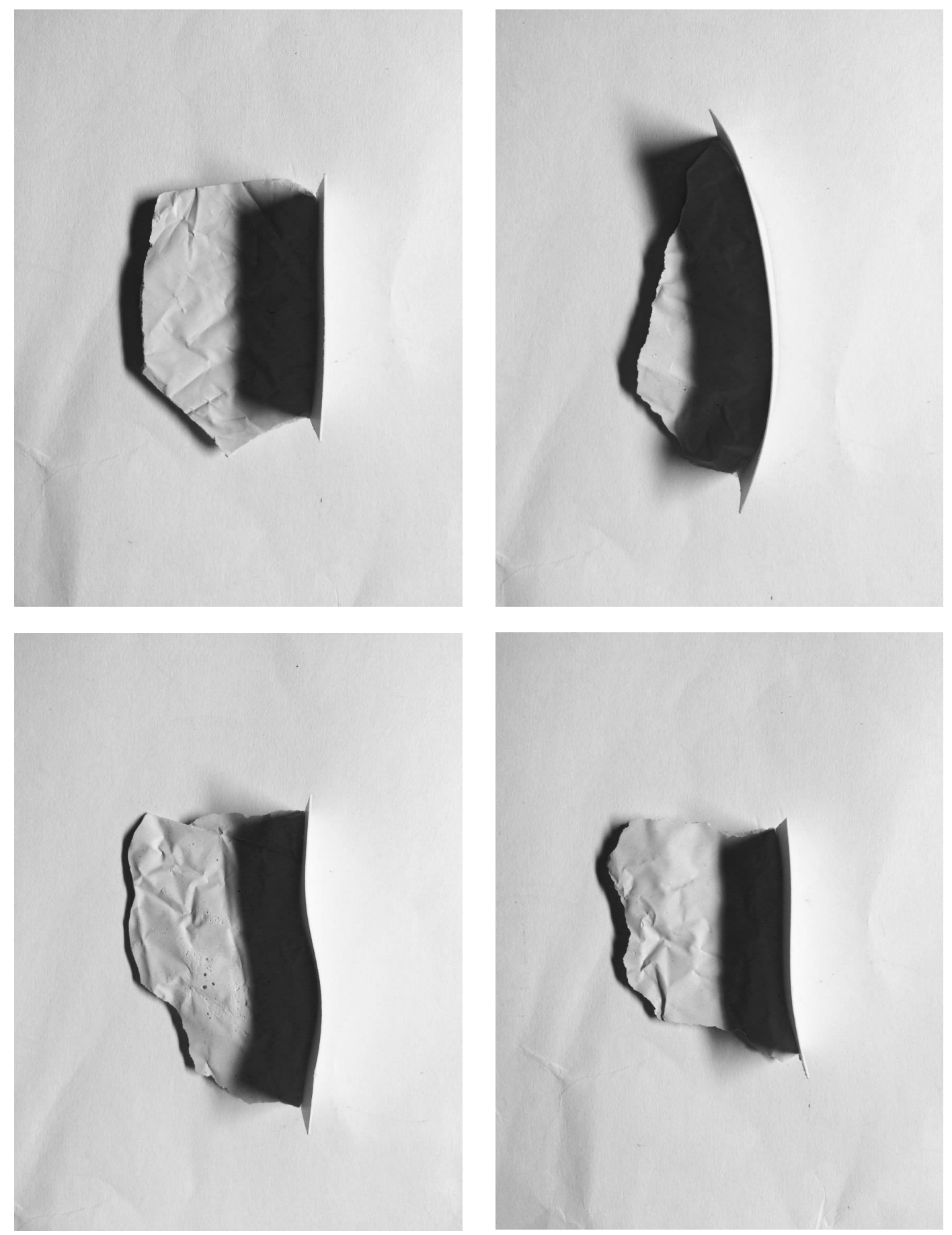

y response to the theories by Mary 1 Miss has been demonstrated with experiments with plaster and card, the plaster forms to represent the rough untamed and vast landscape and the card to act as an intervention, a simple clean cut through the unruly expanse. This experiment was very useful and was used in the final design and preliminary stages where the architecture and landscape have a strong relationship. 



\section{WALTER PICHLER}

1936-2012

THIS CONTENT IS NOT AVAILABLE

PLEASE REFER TO PHYSICAL COPY

Figure 50.

Walter Pichler. 
PLEASE REFER TO PHYSICAL COPY 
$W^{\text {alter Pichler was once a part of Austria's }}$ $W$ post-war avant-garde movement which consisted of a group of Austrian architects who produced art that "defied the status quo." (Grady).

Similar to Chadwick, his theories and case studies are relevant to the objectives for this investigation through his exploration of sculptural form and the way each suggests inhabitation.

"He does not project bliss or innocence into this world; it offers him neither shelter nor protection, it is neither Arcadian nor idyllic. Most of his work involved, quite simply adjusting to the local circumstances, accepting the given realities, even taking advantage of them."

- Friedrich Achleintner (Pichler, 9) 


\section{HOUSE FOR THE WOMAN}

1984

\section{THIS CONTENT IS NOT AVAILABLE}

\section{PLEASE REFER TO PHYSICAL COPY}

Touse for the Woman by Pichler (figure 1 52), shows a plan at the bottoms of the drawing that appears very similar to the objectives that Mary Miss was trying to achieve. What he does that is different to Miss, is that he begins to build an architecture upon this grid-like base so that it becomes a landscape element that inhabits the architectural shell.
The second thing he does is that he brings a carved column and rests it within, not dissimilar from the figures of Chadwick, but this time the figure is the inhabitant inside - architecture inside architecture, landscape inside landscape. 


\section{WOMAN IN METAL}

1990

Toman in Metal (figure 53), where he is moving beyond sculpture and inhabitable spaces can begin be recognised. This provides opportunity for how housing could infiltrate the veil of the Woman in Metal, as a place to inhabit these spaces could offer all different elements of privacy and enclosure seen on the right of the figure versus exposure to the outdoors and engagement with the elements on the left of the figure.
These ideas of inhabiting the abstract have been incorporated in the final design, of each vertical figure providing different inhabitable spaces with varying levels of privacy and exposure. 

The overall problem that this investigation

1 is responding to is refugees returning to a devastated homeland. I have confirmed through these preceding theorists and case studies several specific approaches to how one might integrate speculative architecture with anthropomorphism, with narrative, with the importance of context, and ultimately inhabitation. From transforming the abstract into the architecture.

In daily life one of the biggest issues is that when people walk past buildings they never see them. We are so used to windows, doors, cornices - that we become blind to them. How can the awareness of architecture be reinvigorated? How can architecture capture our attention as we walk by?

The following chapter will present the concept and preliminary design phases which are critiqued on their successfulness of achieving the aims and objectives required for this investigation. 

04

CONCEPT \& SKETCH DESIGN<smiles>[13CH3]</smiles> 
The following chapter documents the 1 iterative design process of this design-led research investigation. There are five phases that begin with early concept experiments and continue through to two resolved preliminary designs.

Each phase within this chapter has been critiqued against the objectives of this thesis to gauge the successfulness of each in order to develop ideas and arrive at a well resolved design solution.

The first stages of the design process were conceptual designs responding to contextual elements of the site in Palmyra, and were carried out whilst the research phase was occurring. The experiments in this phase were about understanding the site, and are laying the foundations for future experiments to be built upon.

They provided important insights, in particular relating to Research Objective 3: to integrate the materiality of the architecture and its context. 

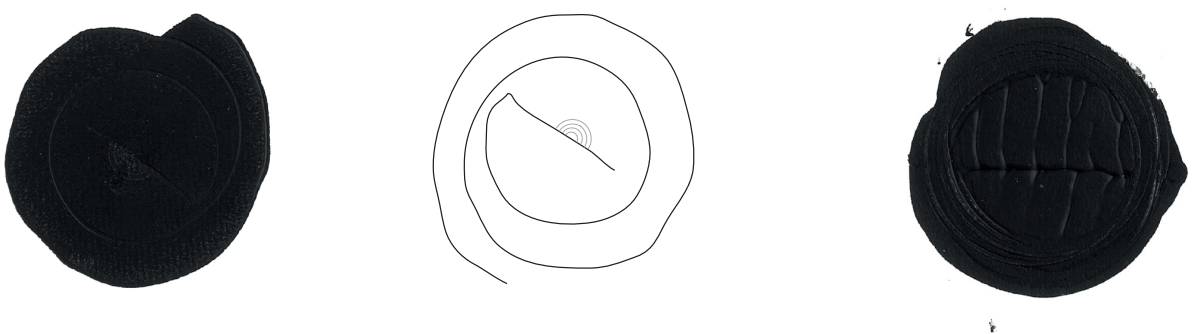

1
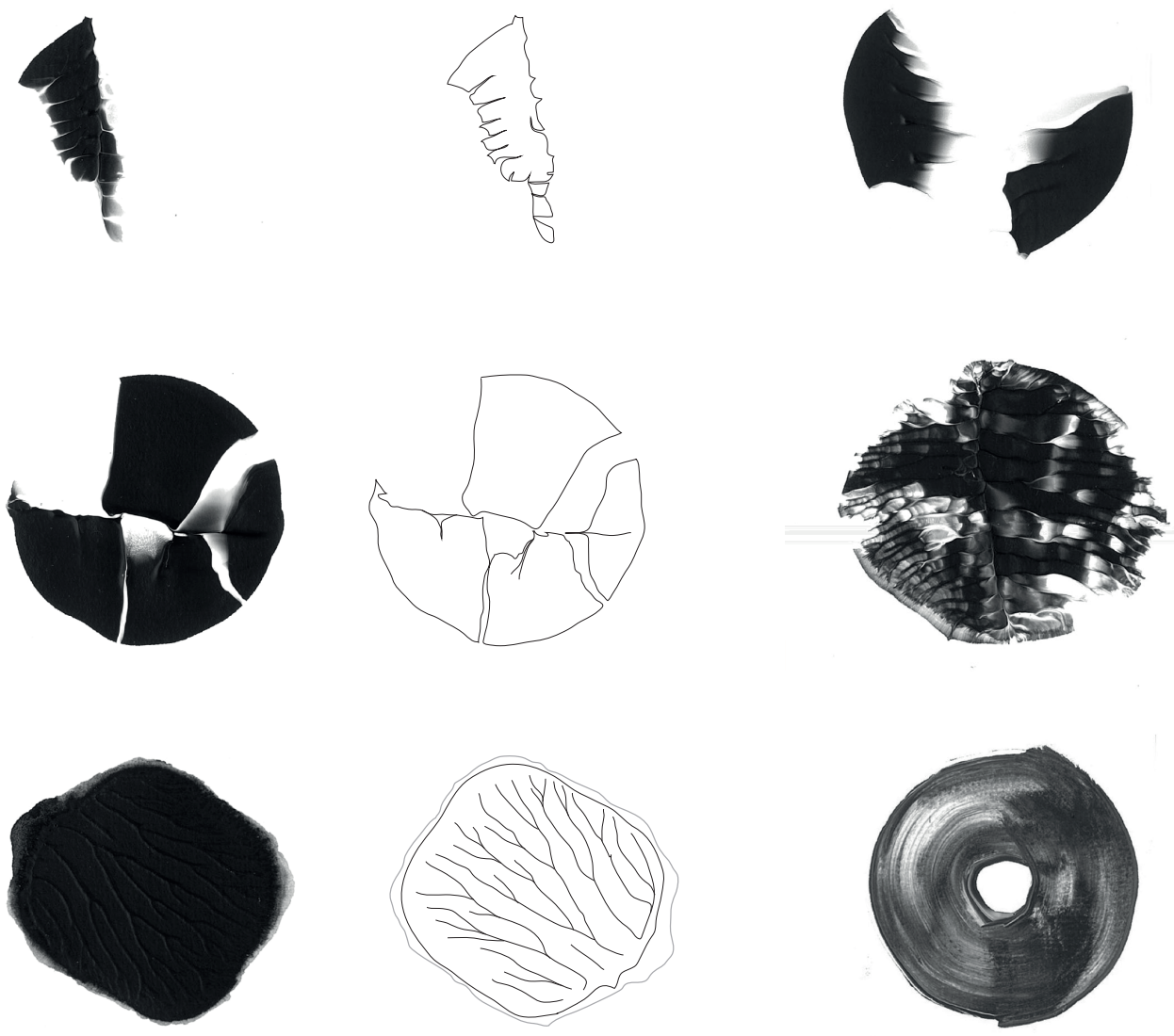

Figure 54

Exploration

of contextual

elements to

understand

vertical

patterns on

site. Paint,

modelling

paste, charcoal

pressed

between

acrylic and

card.

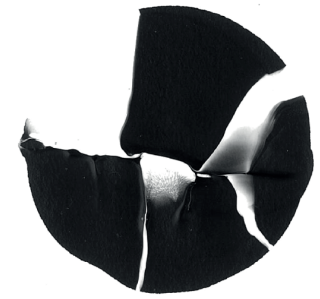



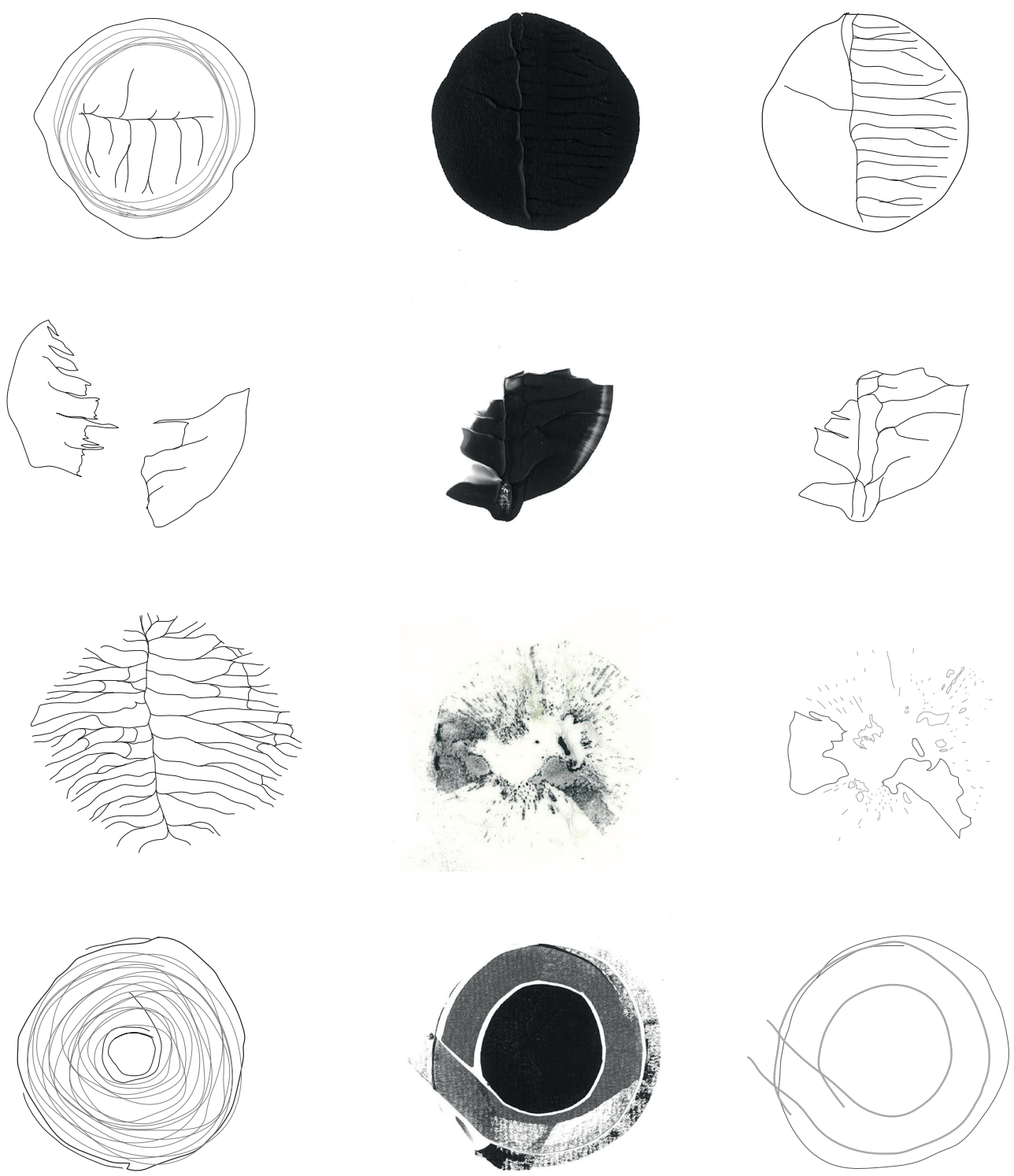

These paintings were one of the earliest 1 design experiments when simultaneously beginning site analysis. They were produced by placing various media: blobs of paint, modelling paste, charcoal, between a card base and an acrylic lid and different movement techniques were applied to each. The outcome was successful in depicting natural elements of site - sand, peaks, mountains, blurring of edges between two medium and allowed a starting point to answering Research Objective 4 , dealing with context and relationship with place. 

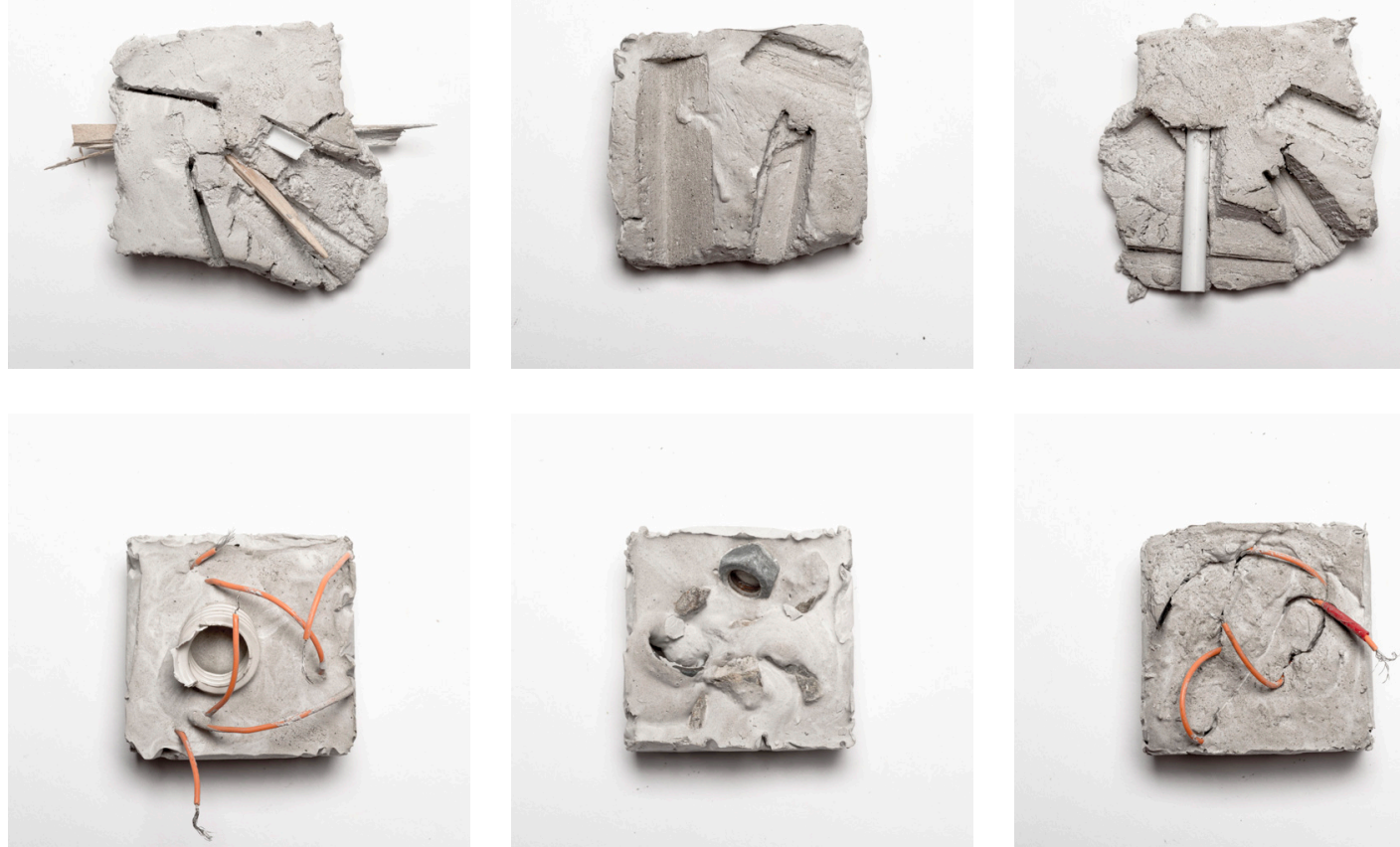

Site

exploration.

Concrete

squares

containing

rubble.
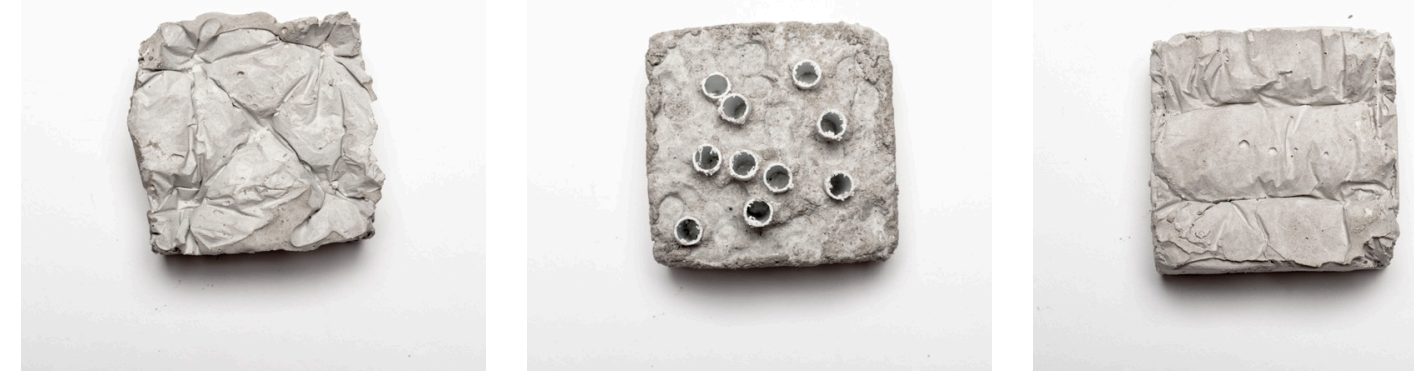
$\prod$ understanding the composition of site, the broken elements, the rubble buried and exposed within the landscape. The conceptual models explore different impressions and fragments of the post-war landscape. These eventually became the precursors of the final response to materiality, and the incorporation of broken fragments into the new building materials as a 'memorial'. 

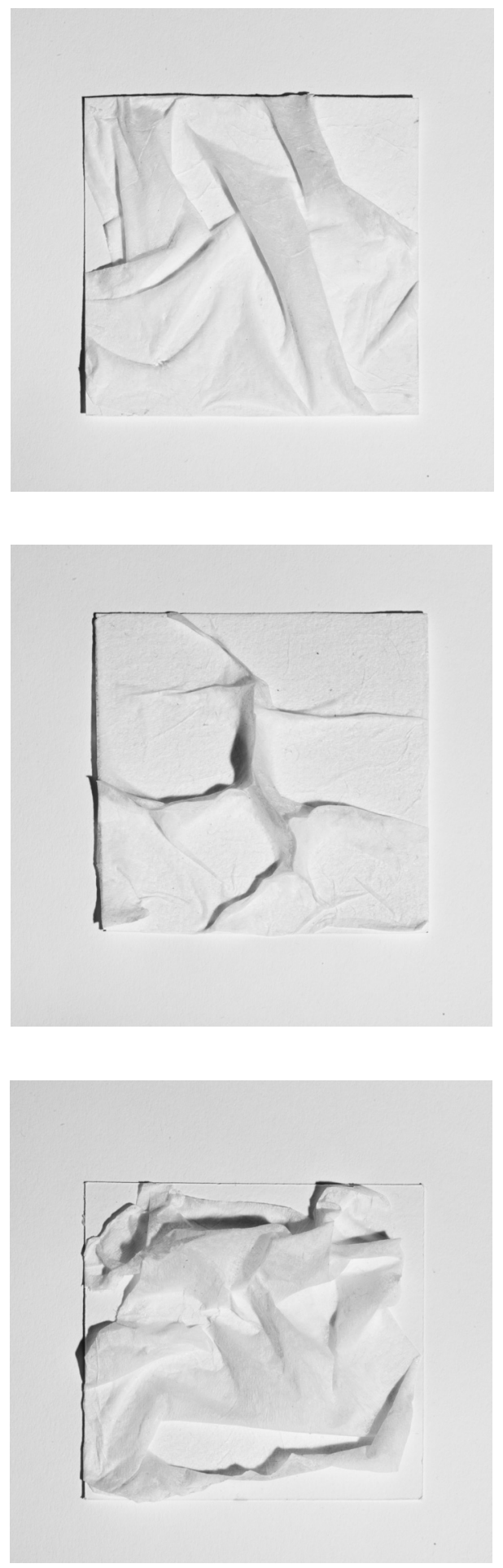

Figure 56. Site exploration.

Textured tissue paper formed on card. 
This was an experiment with a material

1 made from layers of glue and tissue paper. One side was matte and the other side had a rubbery-adhesiveness, and when pressed onto a card base it formed stiff peaks.

One element of site which was fascinating was the vastness of the desert plains in contrast to the mountains and peaks that rise out and frame the plains. This contrasting notion is what these experiments are interpreting.

These eventually became the precursors of the final response to the design site, and the creation of a 'broken' foundation from which the final design intervention arose. 


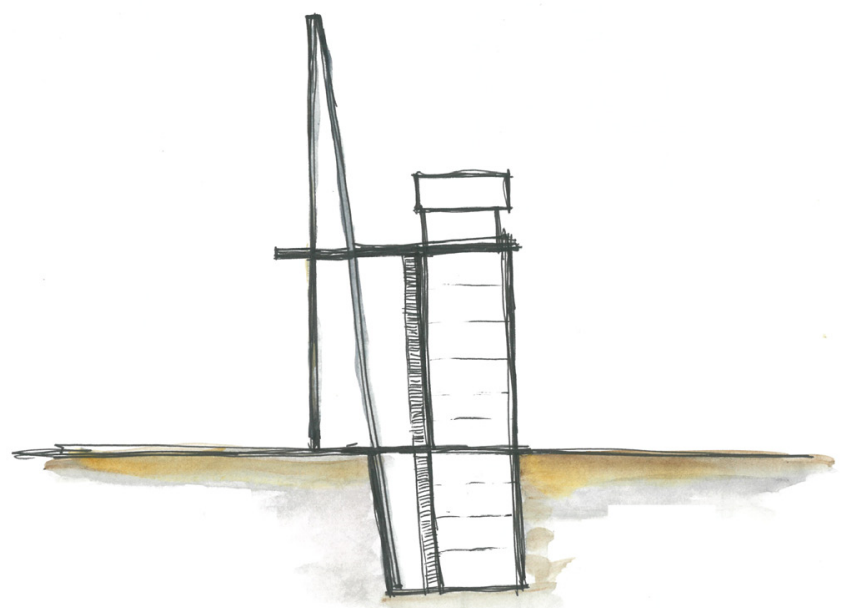

Figure 57. 
The second phase in concept sketch design

1 begins to experiment with siteless built forms within the context of Palmyra. The experiments remain siteless, but are the beginnings of key concepts that are used throughout the design process.

They provided important insights, in particular relating to Research Objective 4: to anthropomorphise an architectural intervention, such that the returning citizens of Palmyra recognise and interpret it as a 'guardian' or 'sentinel' or 'heroine', looking out over their community. 

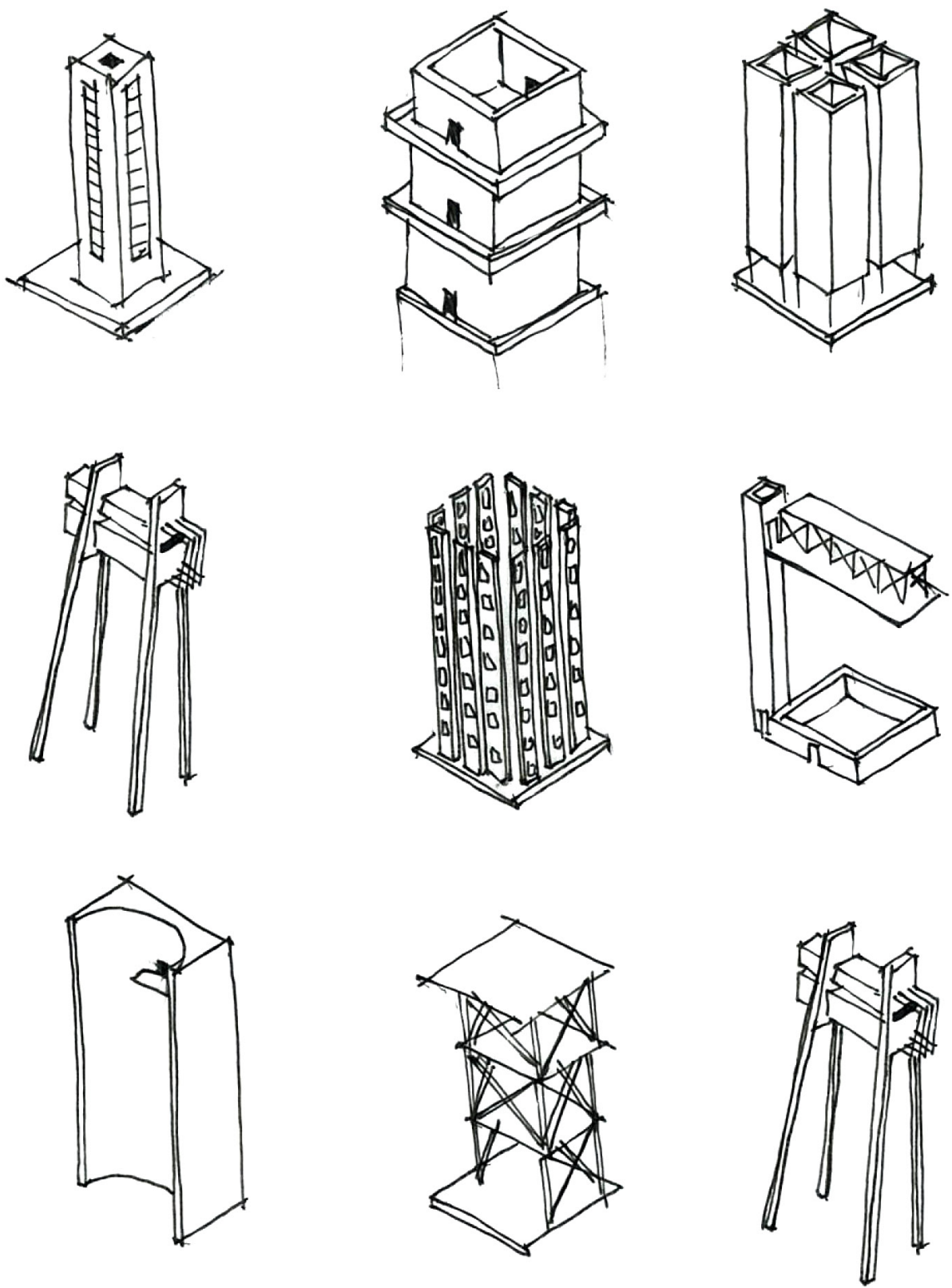

Figure 58.

Initial concept sketches of tower-like forms.

7 his phase began with vertical forms that 1 could act as a observatories, holding a museum or inhabitable area high above the ground with a journey to get there. These sketches show quick fire concepts, with a selection developed later through modelling.

The element of verticality discovered in the grand entrance columns to the ancient city (figure 18) was used throughout the design process as a symbol of hope; the building becomes a monument in the landscape, standing tall and keeping guard over the city. 

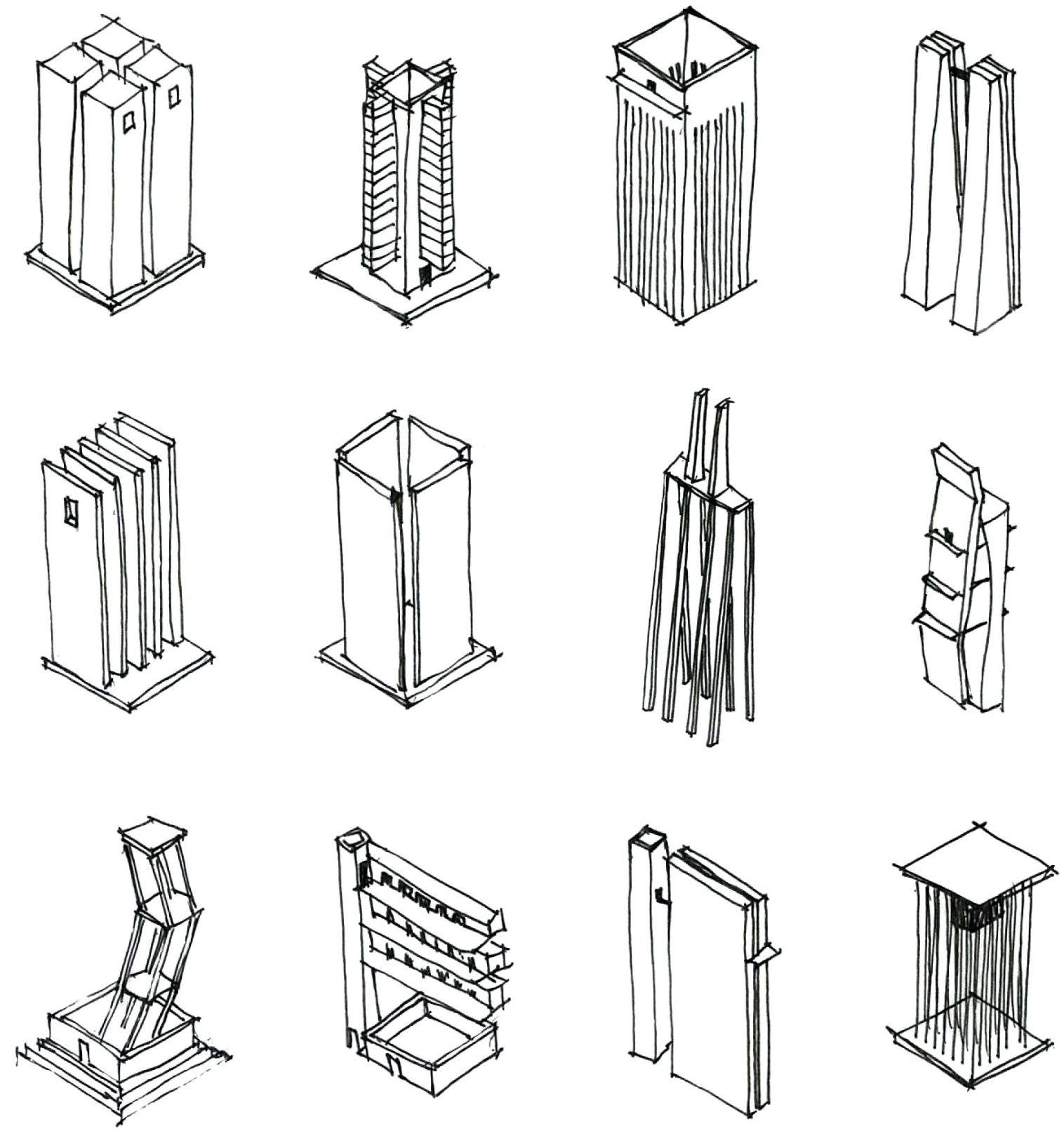

These concepts respond to Research Objective 1 of the investigation as they are of speculative nature and experiment with non-traditional form. The majority are simple, bold geometric forms that offer potential to generate strong patterns of light and shadow. They are also responding to the ancient city, as they all use the same footprint and form as one of the temple tombs.

In this way, they begin to address Research Objective 4, to represent the guardian of a community's history and heritage, pointing inhabitants in the directions of important heritage points in the community's time line. 


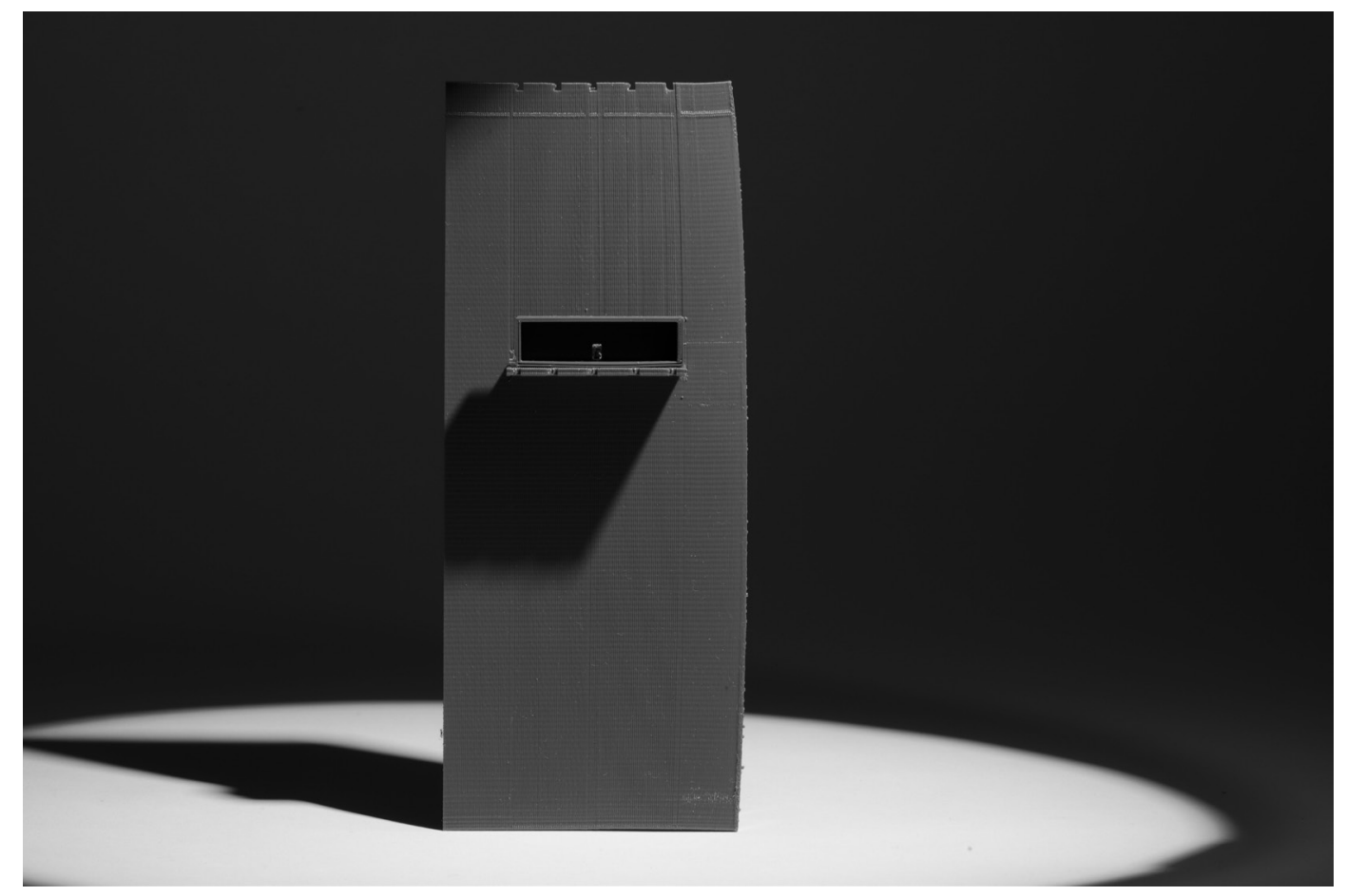

Figure 59.

Model

experiment.

Tower 1. Front.

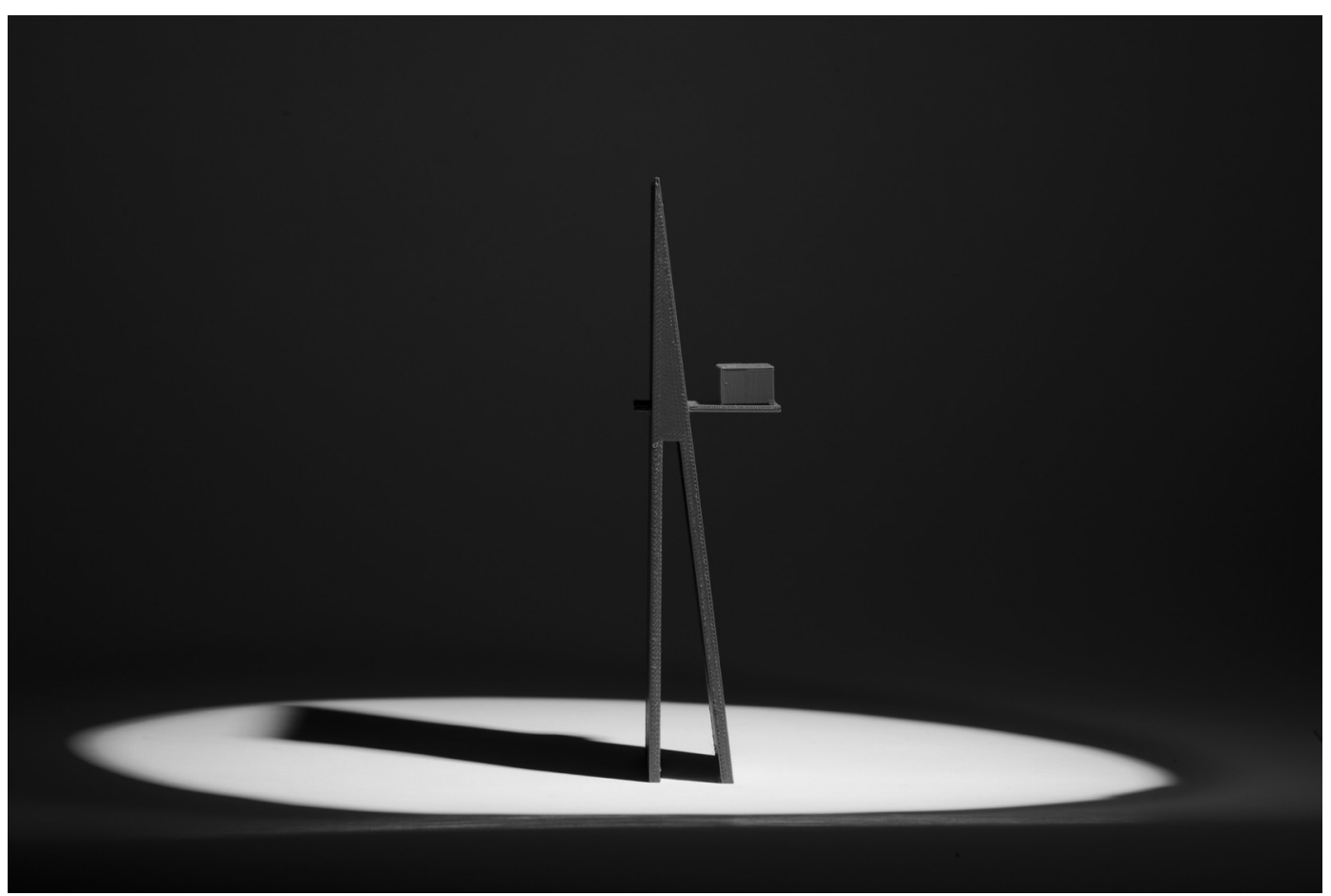

Figure 60.

Model

experiment.

Tower 1. Side. 
This model is a development of the previous 1 sketches, and has become an observatory. There is an enclosed journey leading you up through the legs, and to a platform with an inhabitable volume - a museum, or viewing platform looking out over the city.

Elements of the tower, elements which look out over the city are present here. This experiment was successful in answering objectives of nontraditional forms, simple form, strong light and shadow, narrative through journey and guardian. 


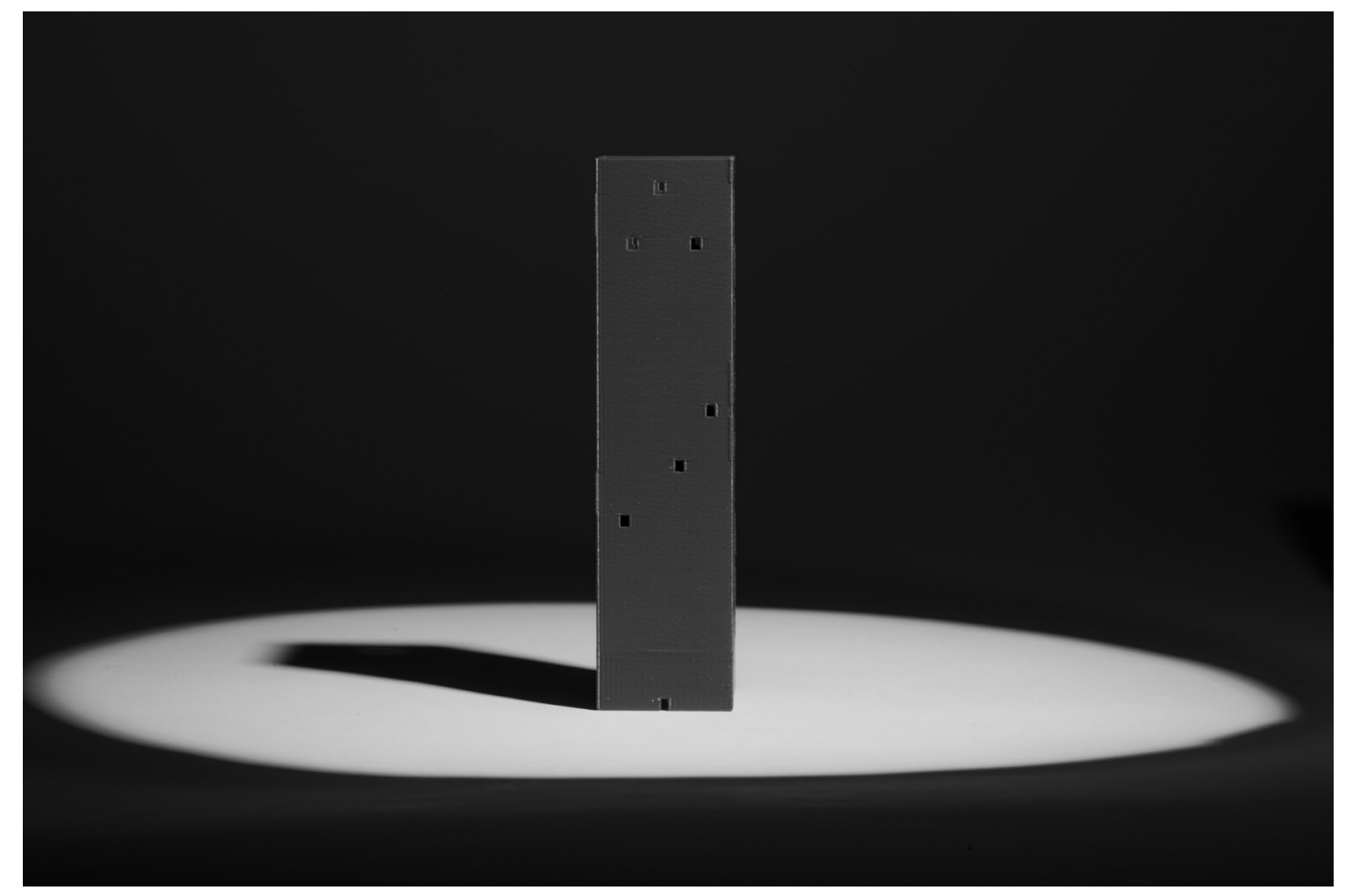

Figure 61

Model

experiment.

Tower 2. Front

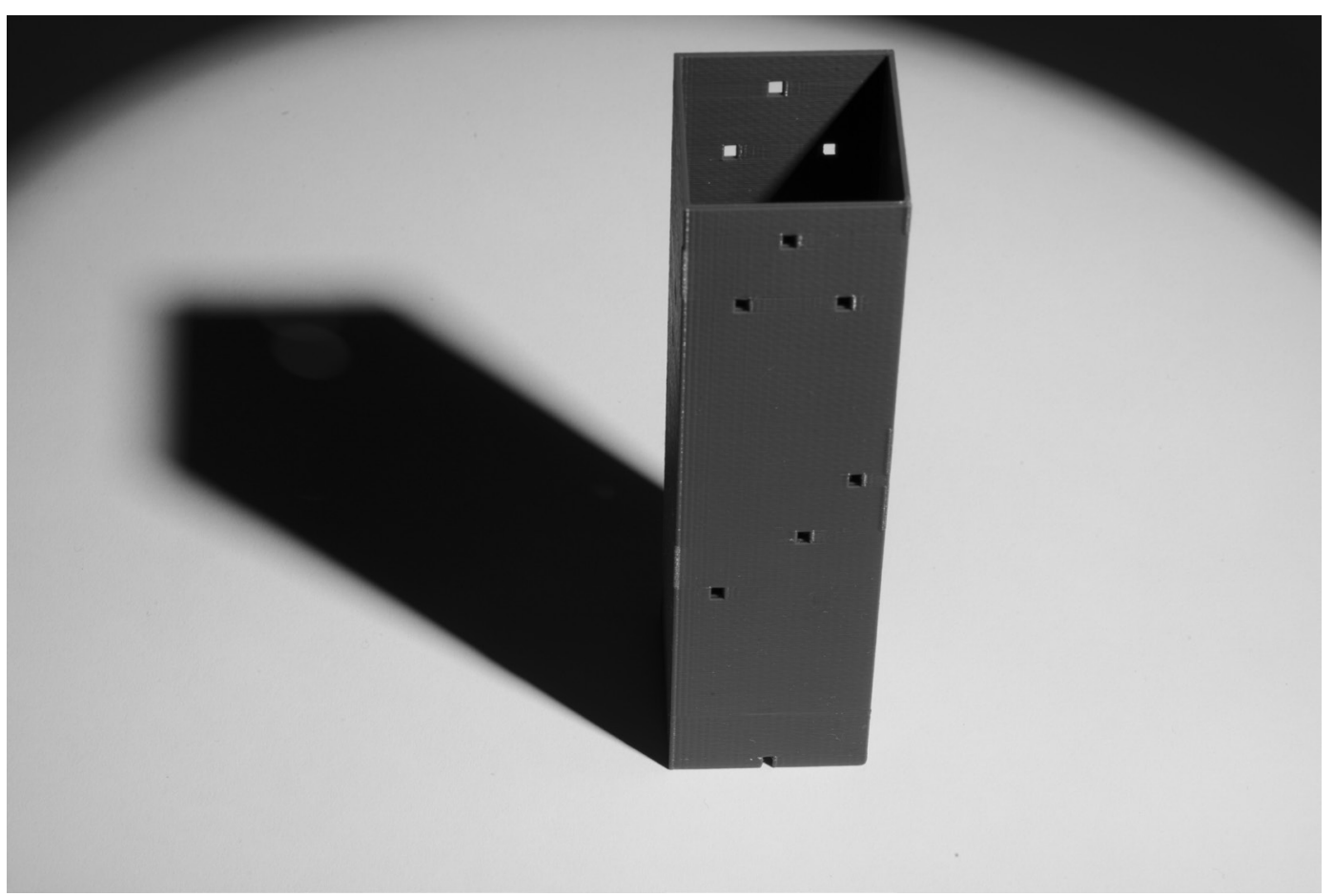

Figure 62

Model

experiment.

Tower 2. 

second development through modelling
the museum element occurring as you journey
up and across allowing the user to view the
city from different perspectives facing different
views.

The idea of framing views and facing different parts of the city was later incorporated into my preliminary and final design. This model responds to objectives of narrative and simple form.

In this way, these experiments begin to address Research Objective 2: to establish an architectural narrative through which the architectural intervention can provide hope to its inhabitants, as well as a renewed sense of the devastating loss being but one chapter in an ongoing time line that has a proud past and a vibrant future ahead. 

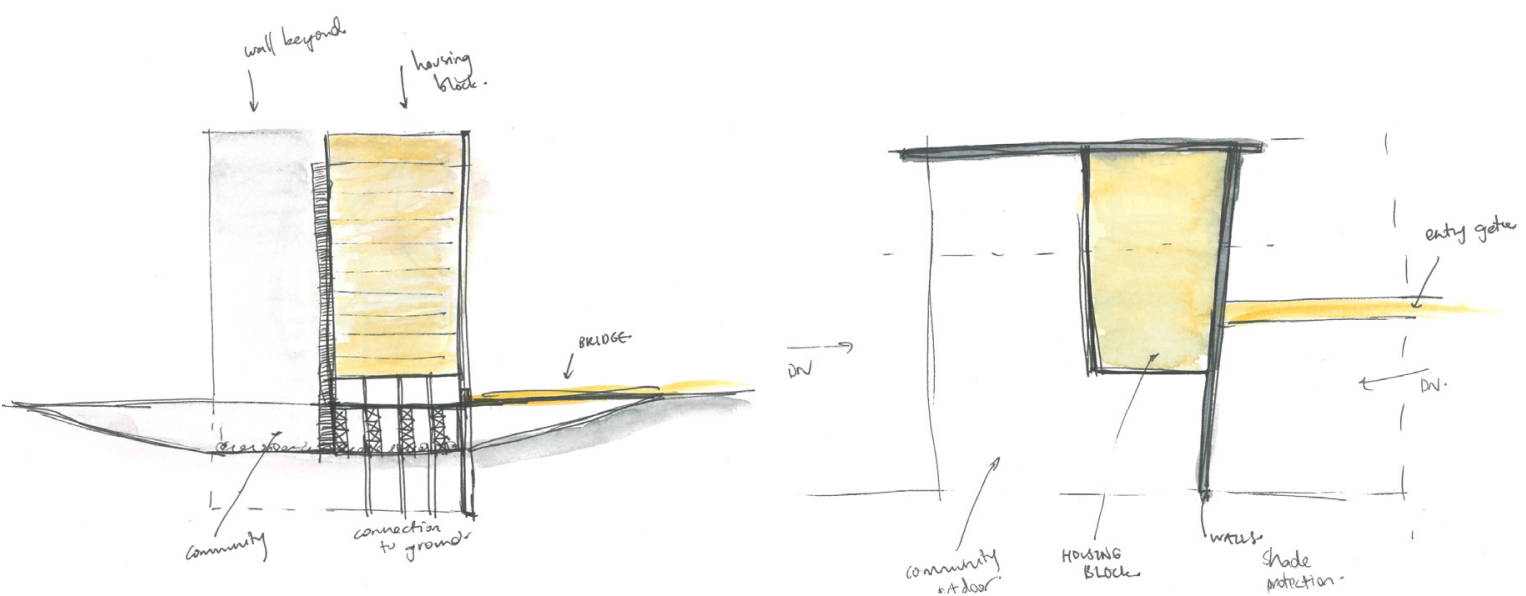

Figure 63.

Concept

sketch.

Inhabiting

forms. Section

(left) and plan

(right).
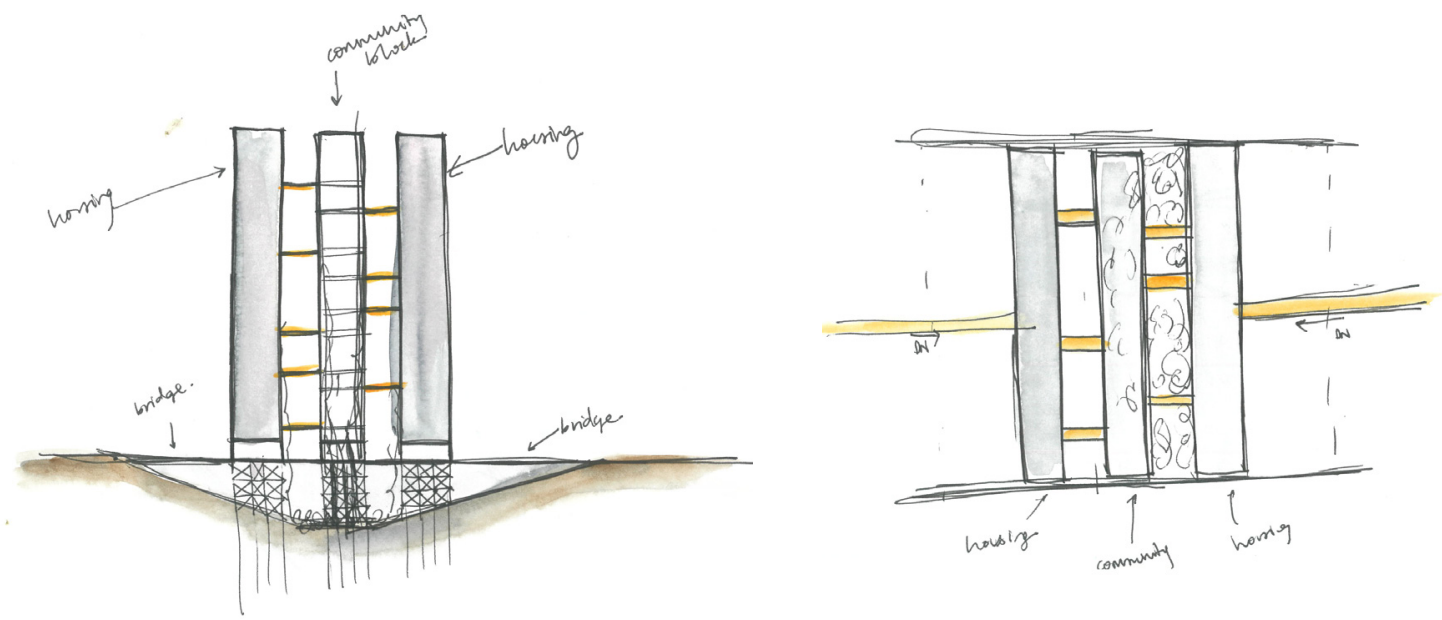

Figure 64

Sketch

experiment.

Towers,

Section (left)

and plan

(right). 
The next phase develops the previous ideas

1 further and presents design experiments that explore how architecture can be perceived metaphorically as a guardian or a hero sitting within or on the outskirts of a devastated city, watching over it, in a place where it can reflect upon the historic attributes of the city that once provided its place identity. 


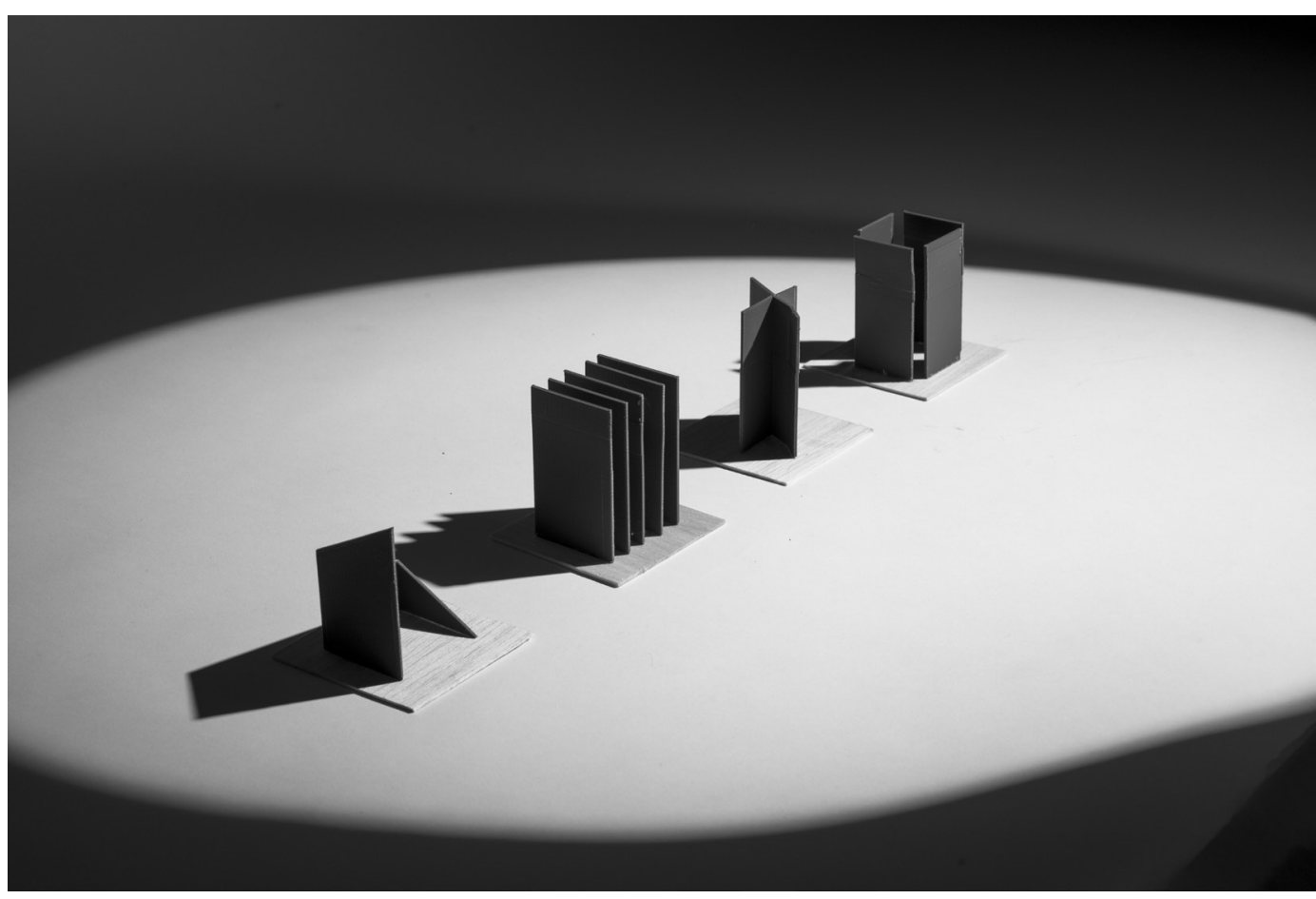

Figure 65

Model

experiment.

Guardians.

Multiple

interventions

across the

landscape.

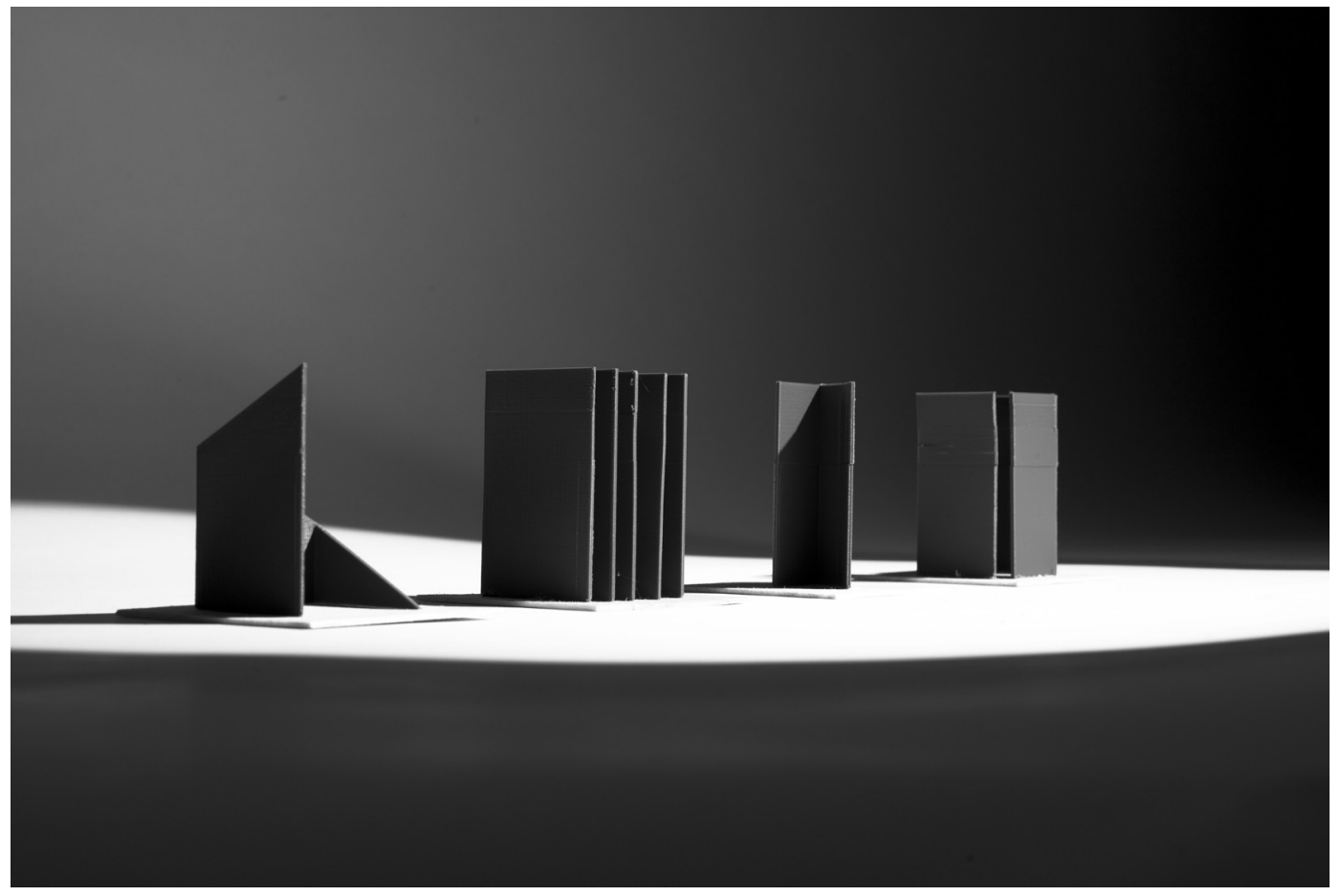

Figure 66

Model

experiment.

Guardians. 
The main idea for this set of experiments placed around the city at important historic locations. The locations identified in the site analysis chapter had not been formalised at this stage.

From this stage, it was evident that a strong connection to the site would make this concept very successful. Therefore the next step was to revisit site analysis to pinpoint the important identity elements of Palmyra, which are the three sites mentioned in the site analysis chapter.

Upon reflection, the forms were also too bold and geometric and ended up appearing as intimidating rather than "sanctuary-like" which was not what the architecture needed to convey in order to meet the research aims.

These experiments provided important insights into how architectural narrative can make connections across the city and the use of bold and simple forms that would rise out of their context. 

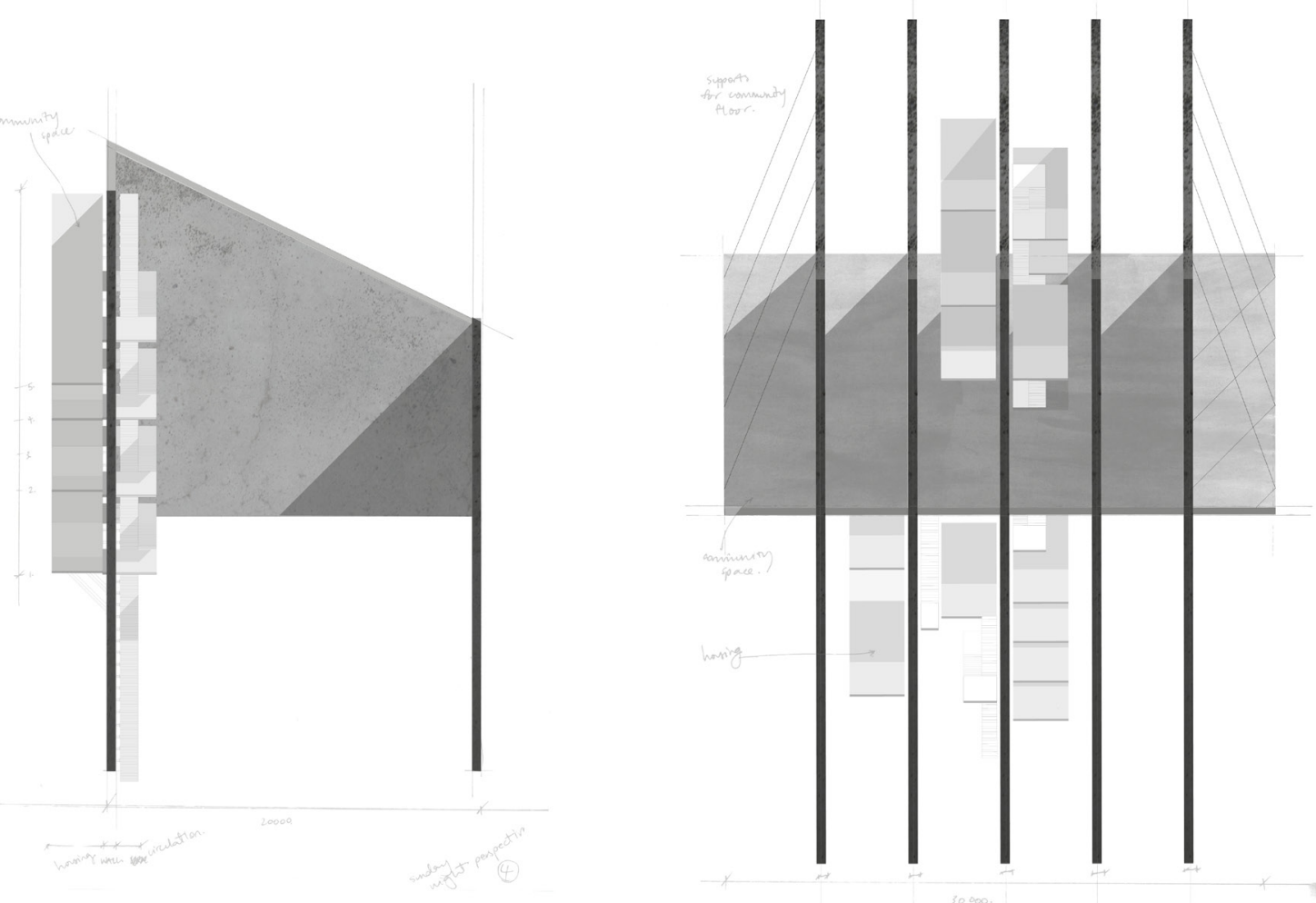

104
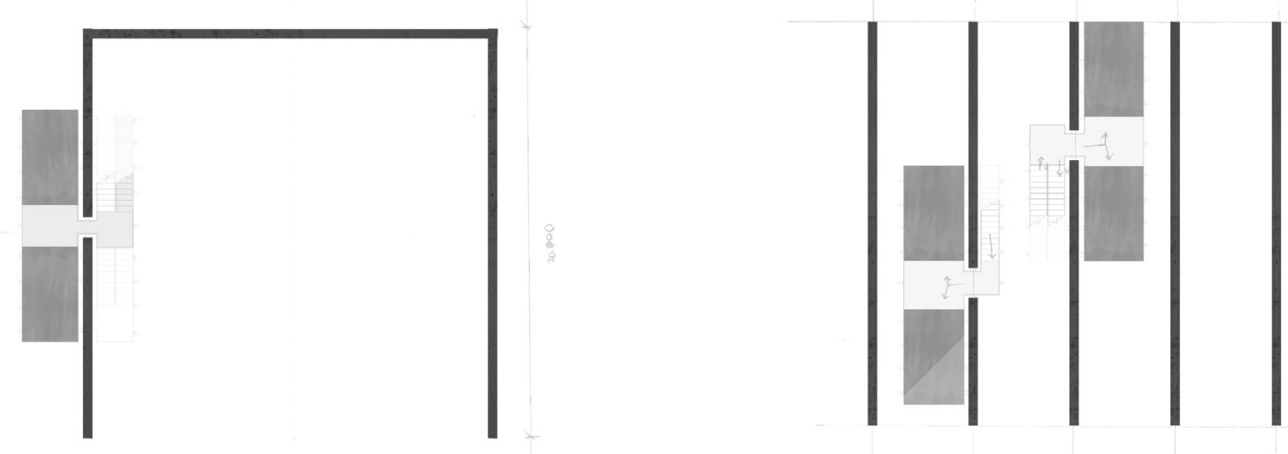

Figure 67.

Flat

axonometric

sketches of

monument

series.

Inhabitation.

These experiments provided insights

1 into Research Objective 5: to translate a

speculative, anthropomorphised, narrative

intervention into habitable architecture. 

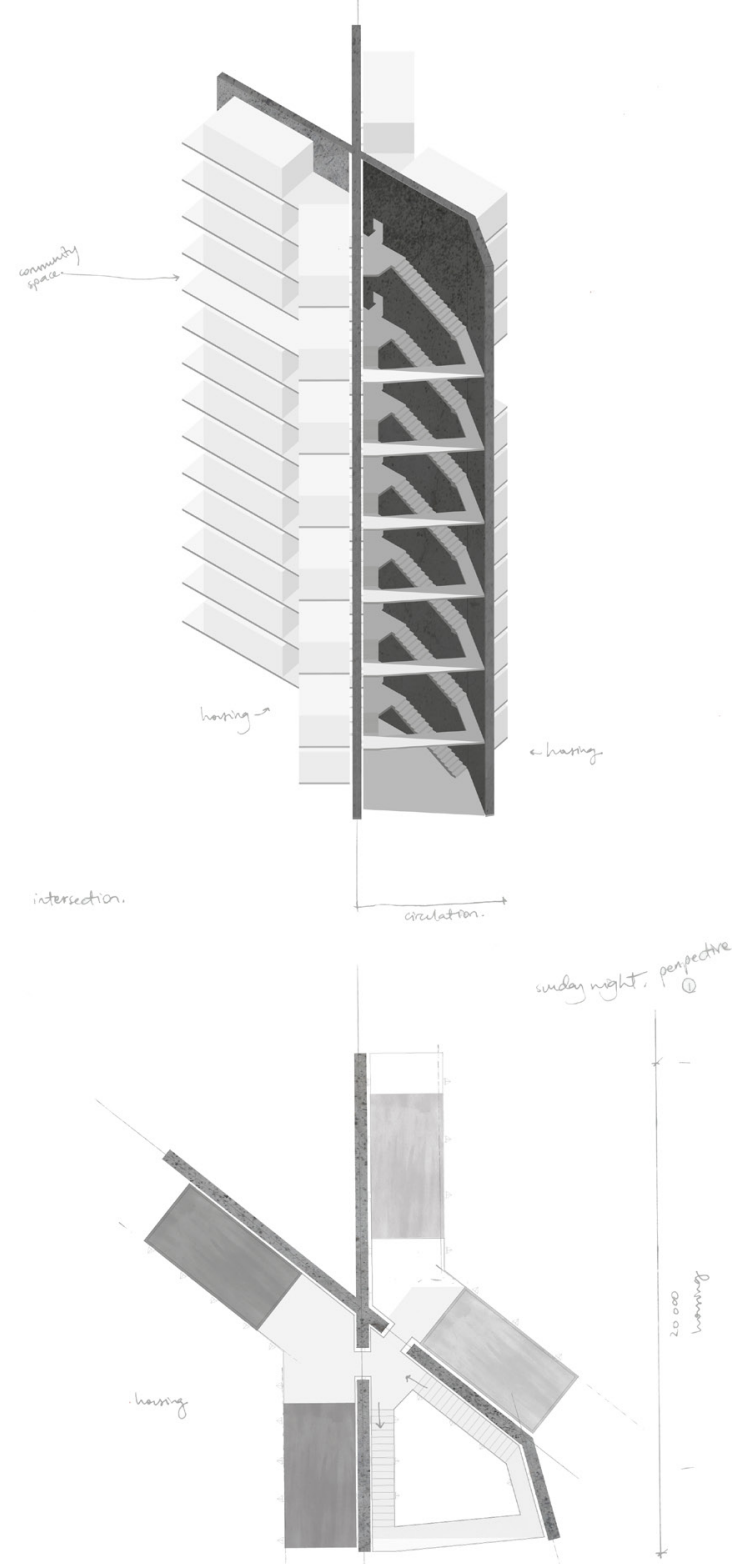
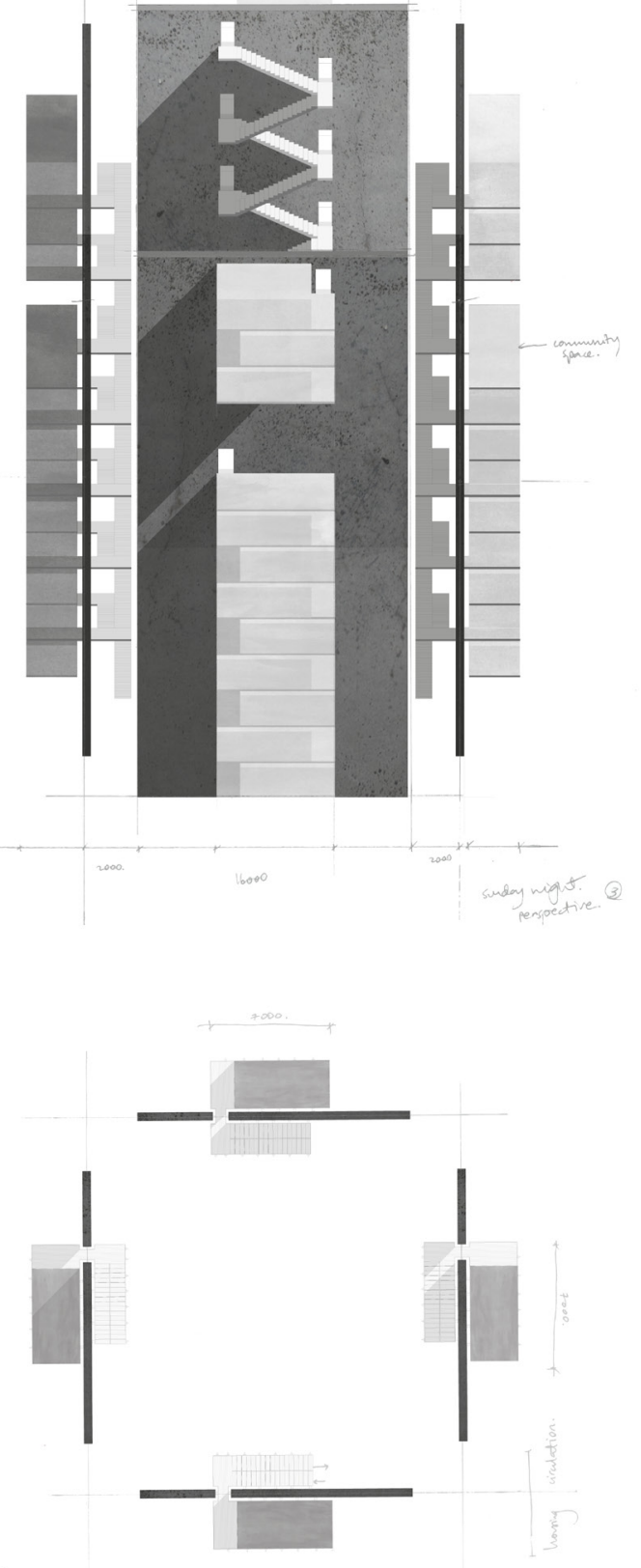

05

PRELIMINARY DESIGN 


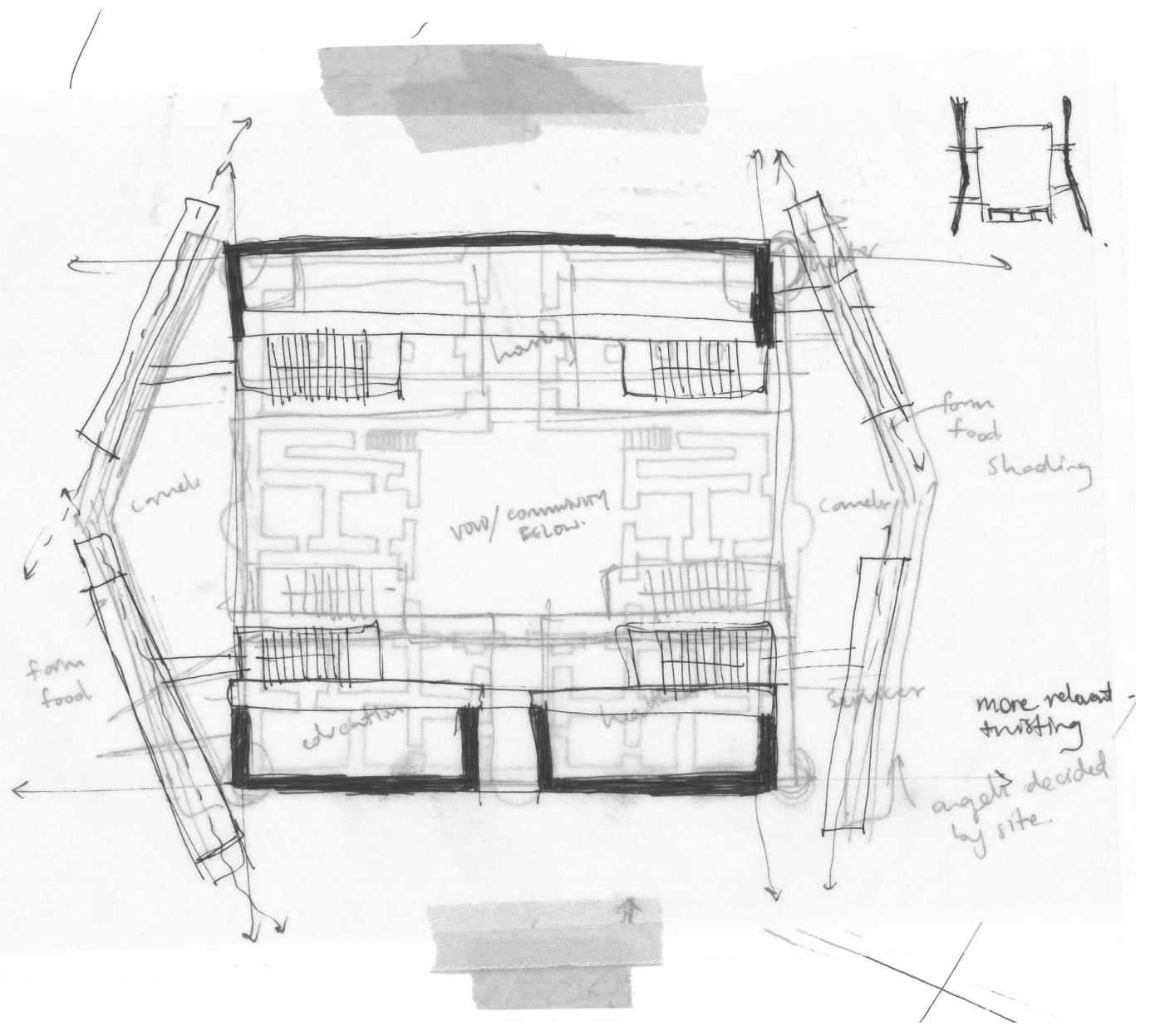

Figure 68.

Prelim

sketches.

Inhabiting

forms.

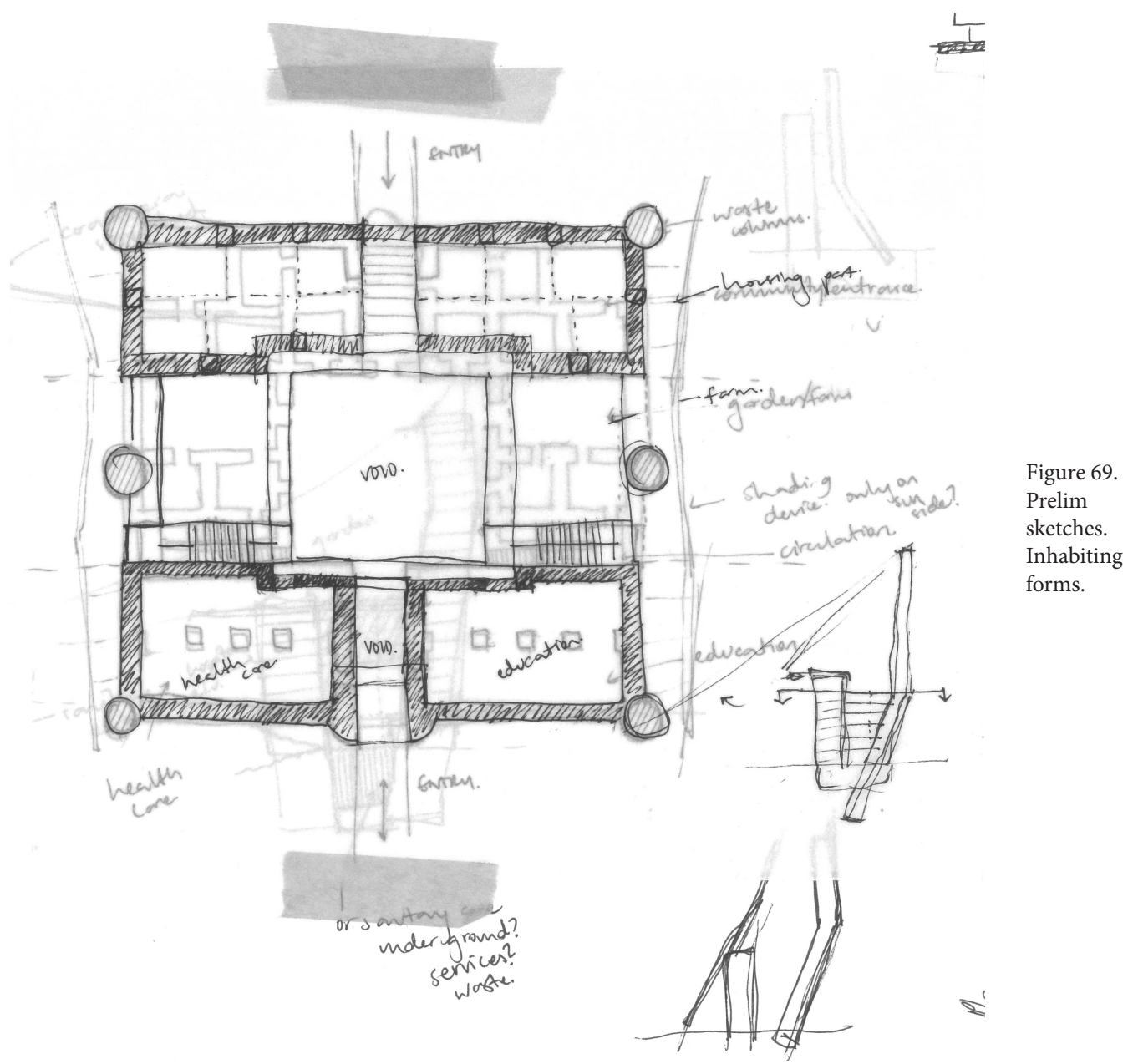


This chapter presents two resolved

1 preliminary designs that have built upon previous experiments and literary research.

The challenge that this phase presented was the combining of puzzle pieces from previous experiments and research that I wanted to bring together to become a whole. 


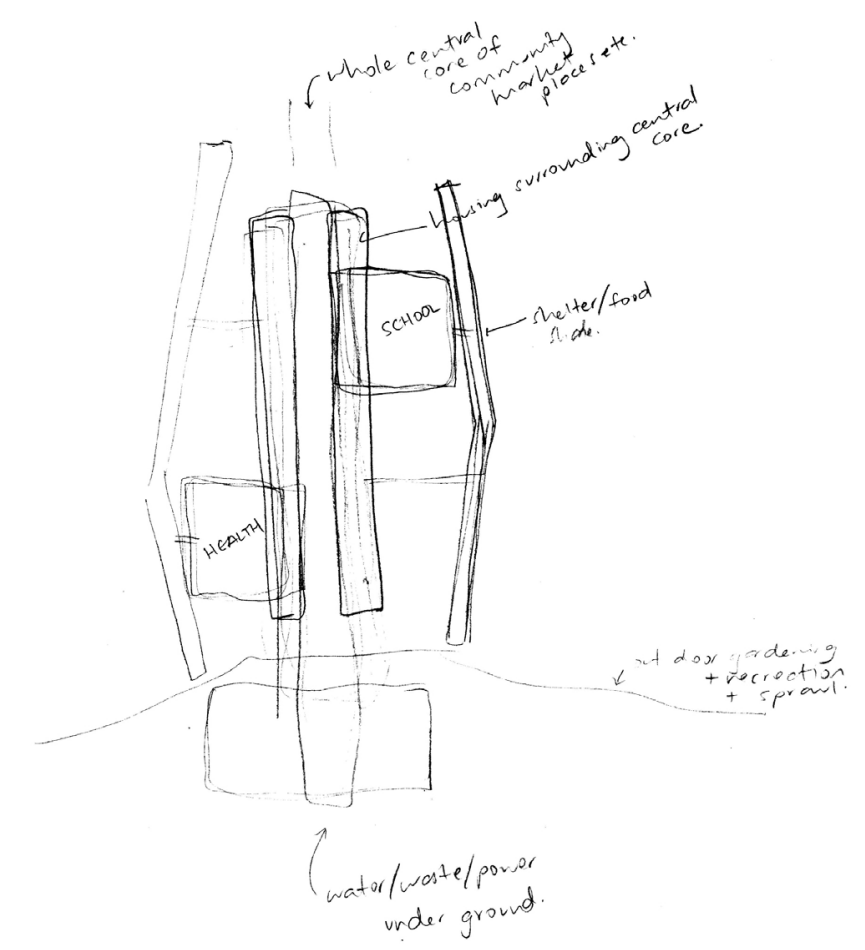


Txperiments in this chapter are around Ethe combination of speculative concept and historic site identity elements, as well as considering formal composition and metaphoric programmatic elements needed for people to inhabit - places to learn, repair and find shelter. These designs were the first attempts to respond to all five research objectives.

The following designs were presented in the July mid-year review, where advice from the critics was to look into more realistic precedents, and how it could actually be functionally used, as well as to make sure the project was true to what I was passionate about. 


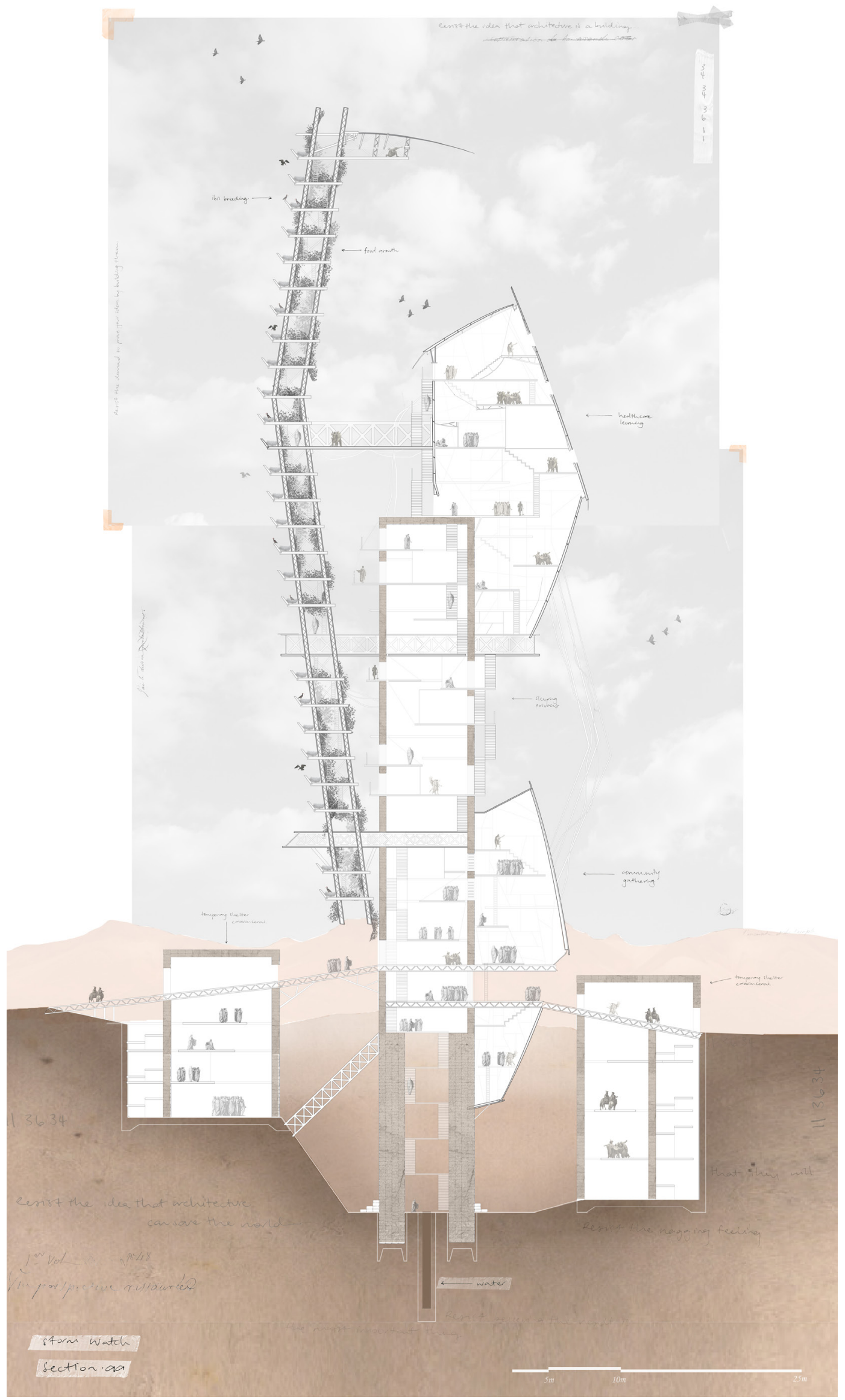

Figure 71.

Prelim design

1. Section 
Figure 72

Concept

sketch.

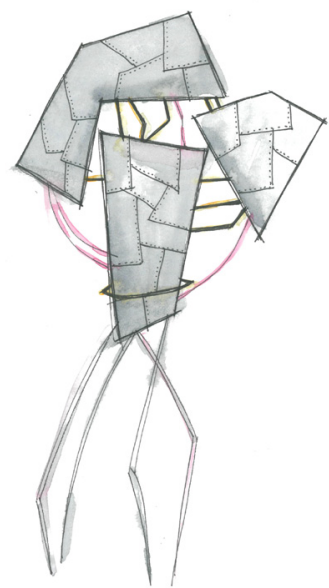

The first preliminary design uses elements 1 of the caravanserai, as an entrance buffer for short term guests or travellers.

Also reminiscent of the caravanserai, in the centre of the inhabitable edge there is a towering form containing public spaces that embrace the private spaces in the centre.

The arm that extends upward functions as places for food growth and observation, as well as a nesting ground for a native bird population whose breeding ground had been destroyed. 


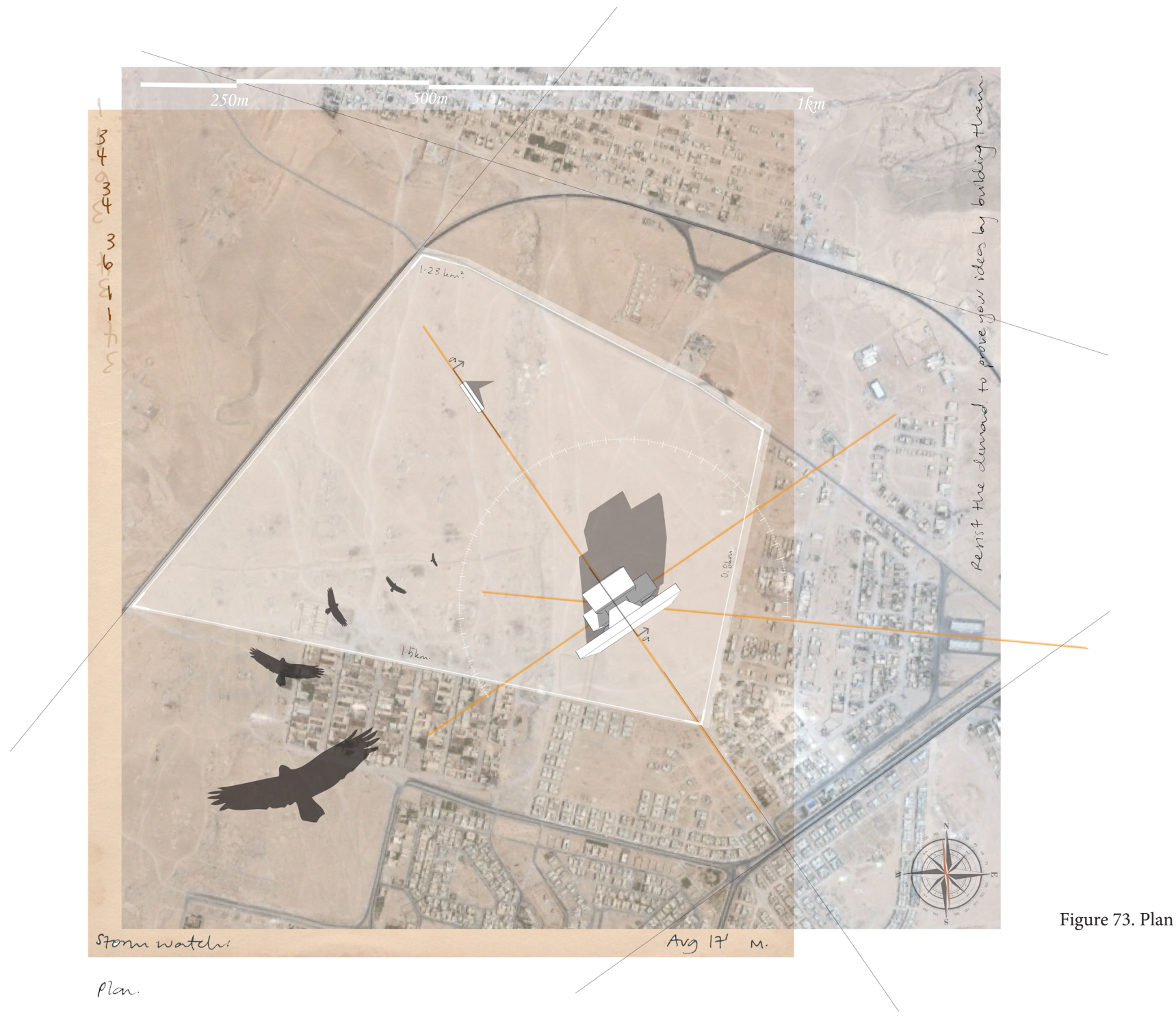


Figure 74

Exterior views.
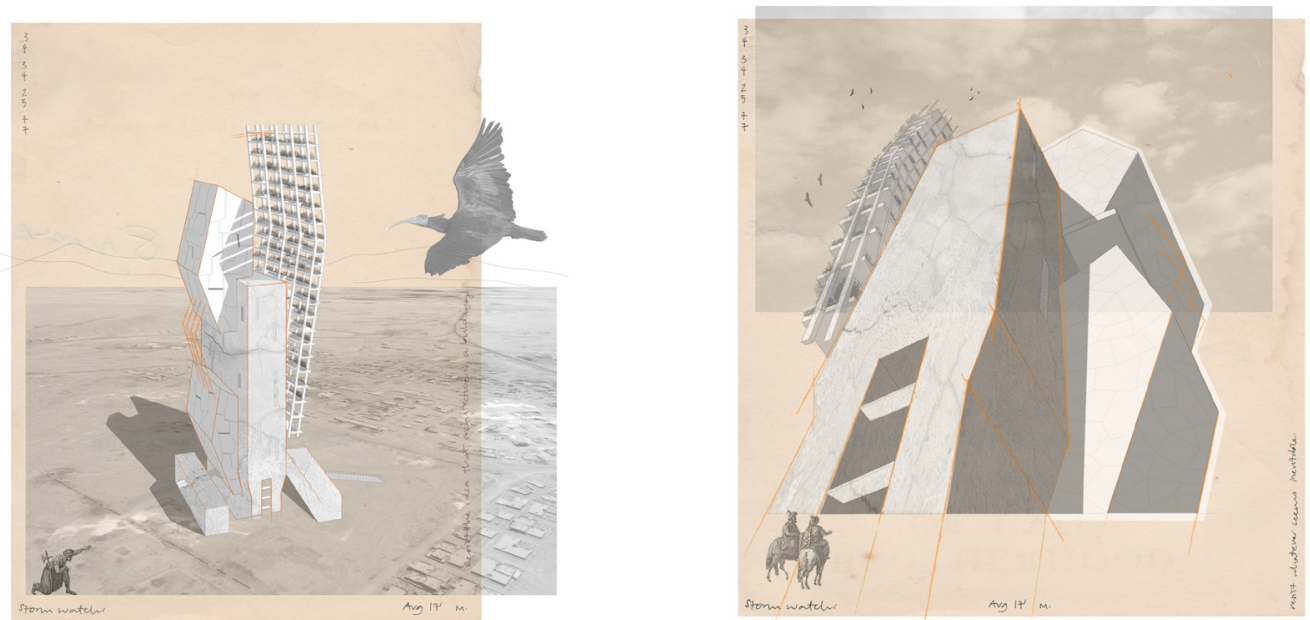

Figure 75

Zoom-in
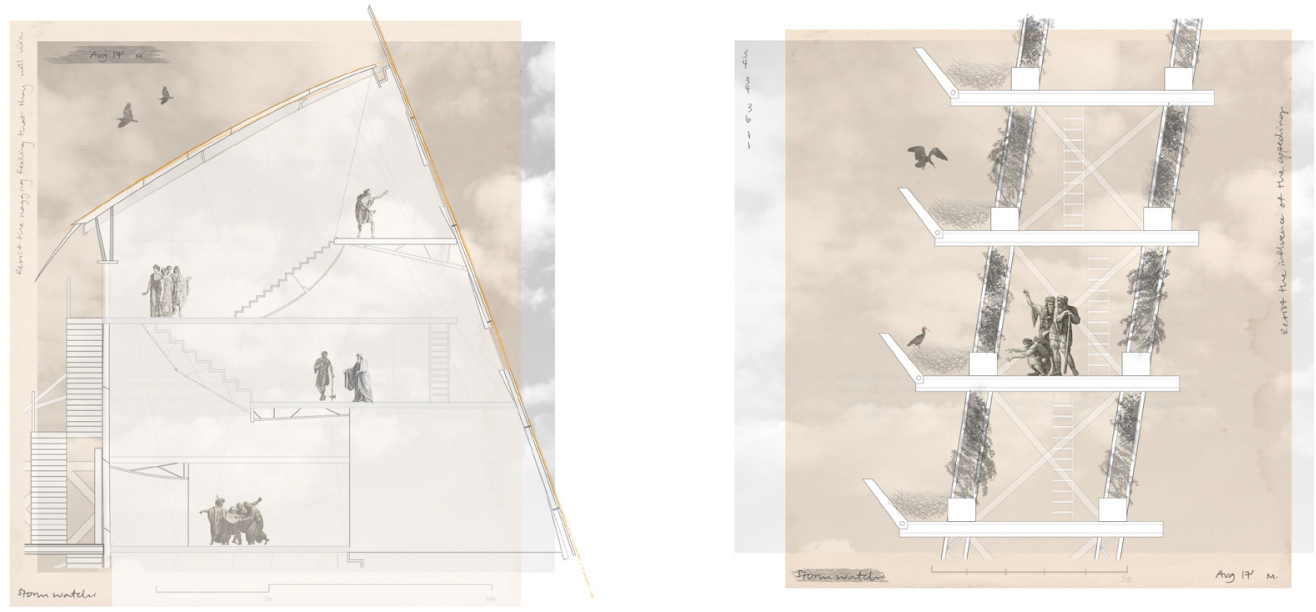

Uccessful attributes of this first preliminary $\checkmark$ design are the use of nontraditional forms, the inclusion of narrative through caravanserai elements, and connecting views to historic sites in the city, and suggestion of how the spaces would be inhabited.

Opportunities for the next design phase: The base of this design is embedded within the landscape, but does not blend well and the towering form extends unsympathetic to the landscape. Whilst being aligned on one important axis point in the urban grid, there were still many important site elements that needed to be incorporated in the final design phase. 


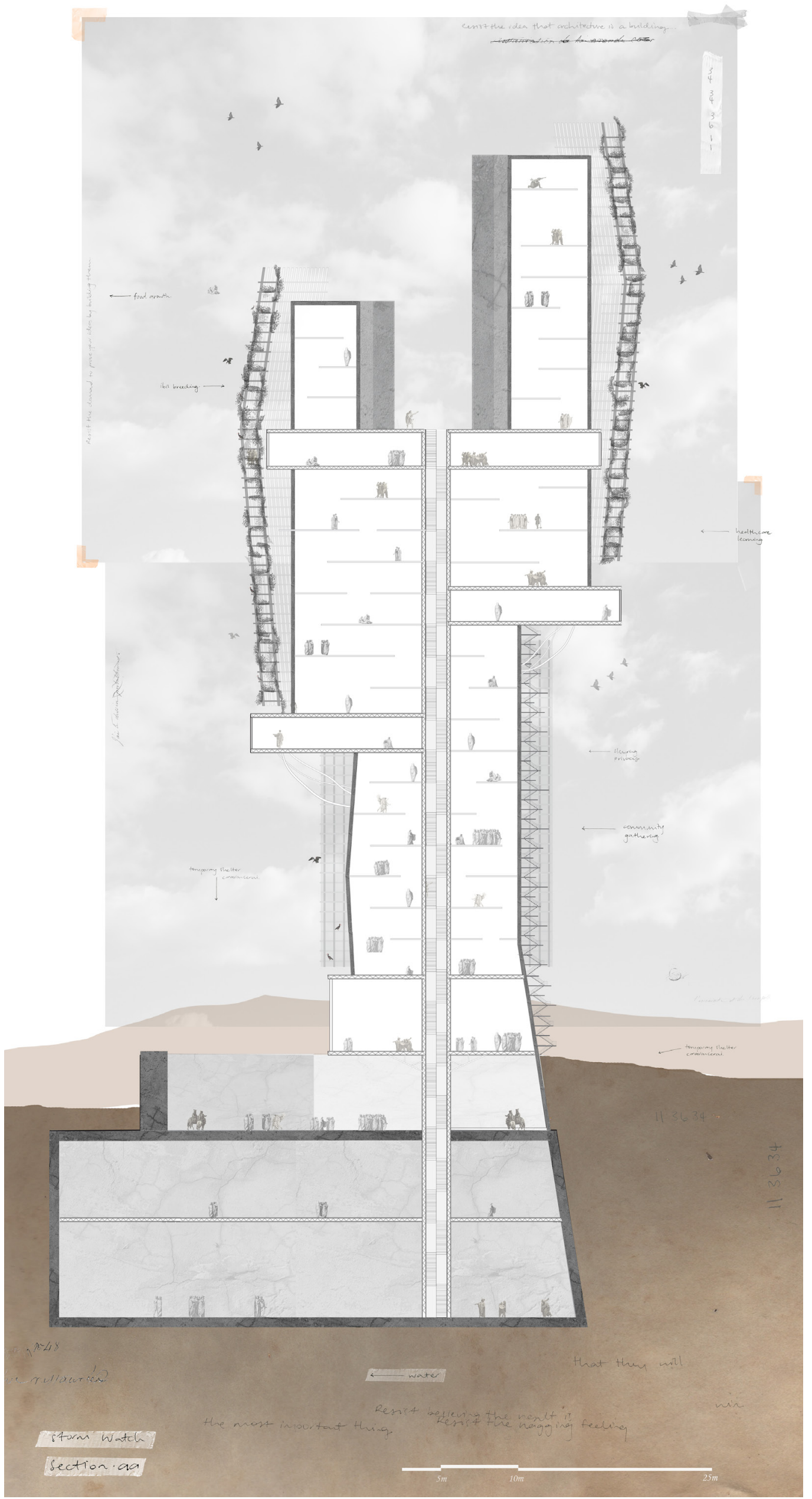

Figure 76. 


\begin{abstract}
$A s$ a development of the first preliminary $A_{\text {design, this second attempt incorporates }}$ elements that were omitted or unresolved in the first.

This preliminary design solution incorporates three bodies that twist to face historic elements in the city - one body contains housing and private shelter, the second contains space to repair and health spaces, and the third contains spaces to learn. Community gathering spaces and service spaces are spread vertically throughout the building, and intersect the three main bodies horizontally. The objective was to provide a sense of community to the returning refugees who now share an important common history and can act as a community to move forward.
\end{abstract}

The base is embedded within the landscape and has services below ground such as recycling, waste and water plants. 


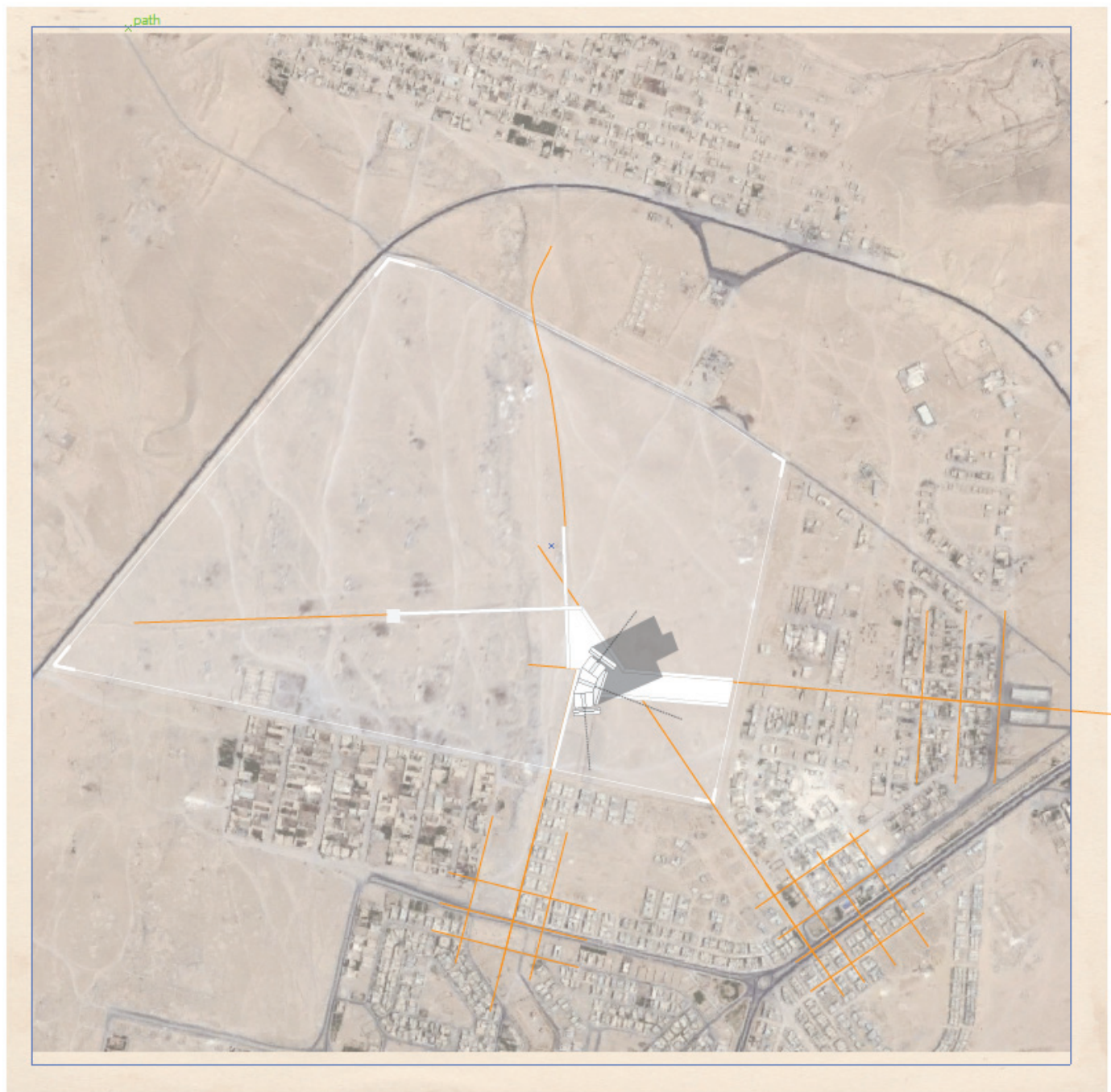

Figure 77. Plan of preliminary design 2.0.

Tn plan, there is a large area on the ground level for entry purposes and community gathering. The entrances are determined by alignments found in the immediate landscape, recognising the intersection of the shifting orthogonal and fluid urban grids from the modern city, and projecting access to future development in the north.

Successful elements of this design include the facing of volumes towards historic sites in the city, setting up a narrative that tells a story of the broken site. The other strong success is the way in which the base sits within the landscape, responding to the work of Mary Miss and the objective of blending between landscape and architecture. Architecture, which is refined further as later developments through modelling. 


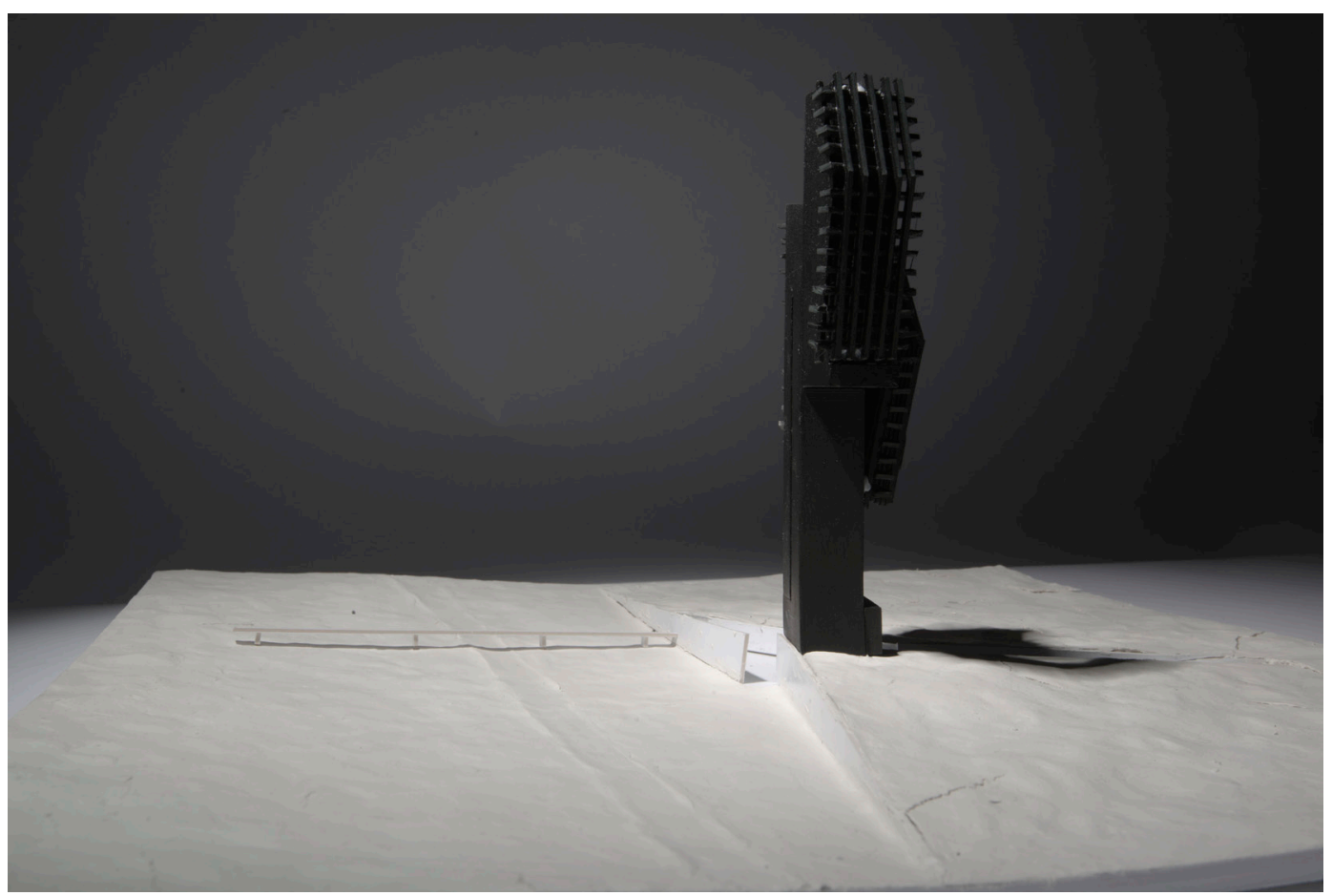

Opportunities for the next design phase: Upon reflection, the two preliminary designs were successful in some ways, but also unsuccessful in others. Neither of these completely answered the research objectives.

For the final design, each of these experiments was de-constructed and the most successful elements were reassembled to fulfil the objectives of this investigation.

After this phase, I revisited site analysis again, revisited the theorists who initially inspired the design process, and dove deeper into what each historic site had to offer, what each meant to the city - and how their ideas could be expressed. 


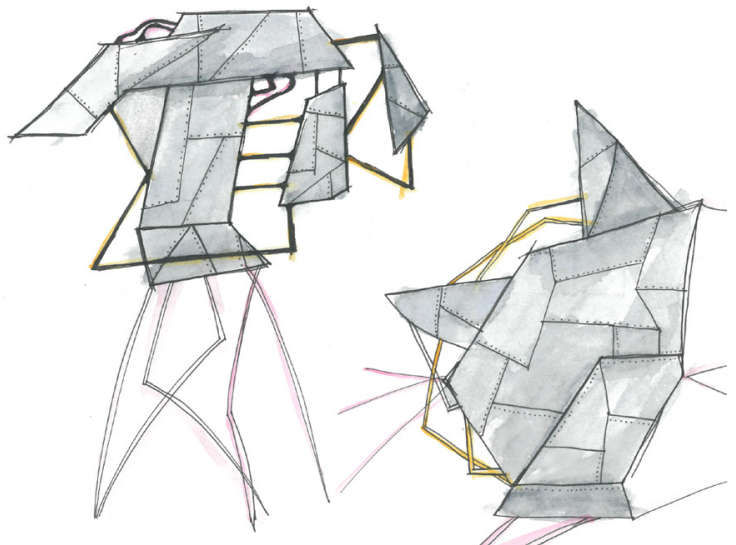

Figure 79.

Concept

sketch.

Figure 80 .

Concept

sketch.

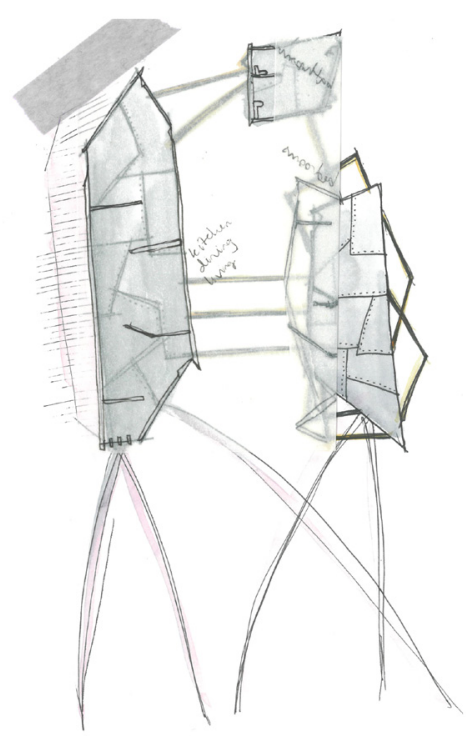

Figure 81.

Concept

sketch.

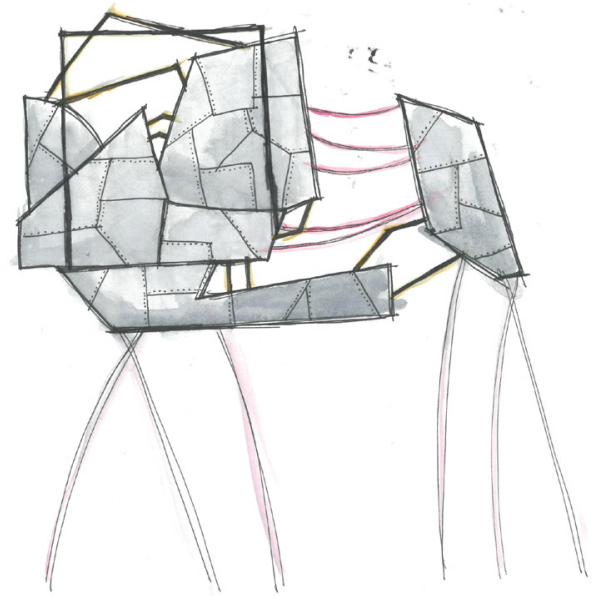

Figure 82.

Concept sketch. 
$A_{\text {literature by theorists, the next phase of }}^{\text {fter revisiting site analysis and }}$ experiments focus on the important historic sites in Palmyra that were mentioned in the site analysis chapter.

Each site is expressed through drawing and modelling with the aim of associating a deeper identity and meaning to each to strengthen the objective of narrative for a final design solution. The abstract sketches are the beginnings of this and are then further developed into models.

Other objectives that are addressed in this phase include the creation of abstract,

nontraditional forms, a speculative scheme and the notion of narrative is explored. 

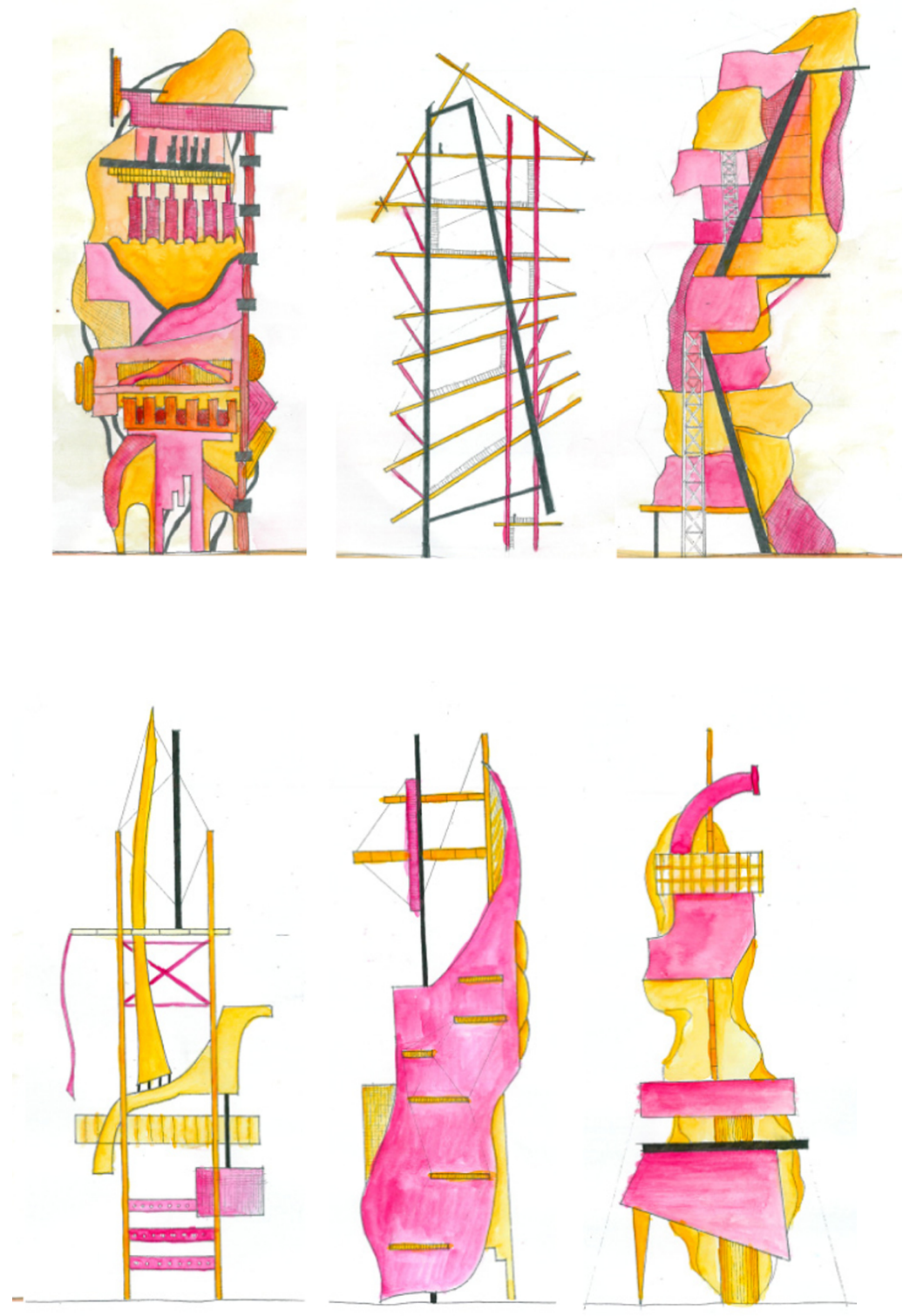

Figure 83.

Observatory

concept

sketches.
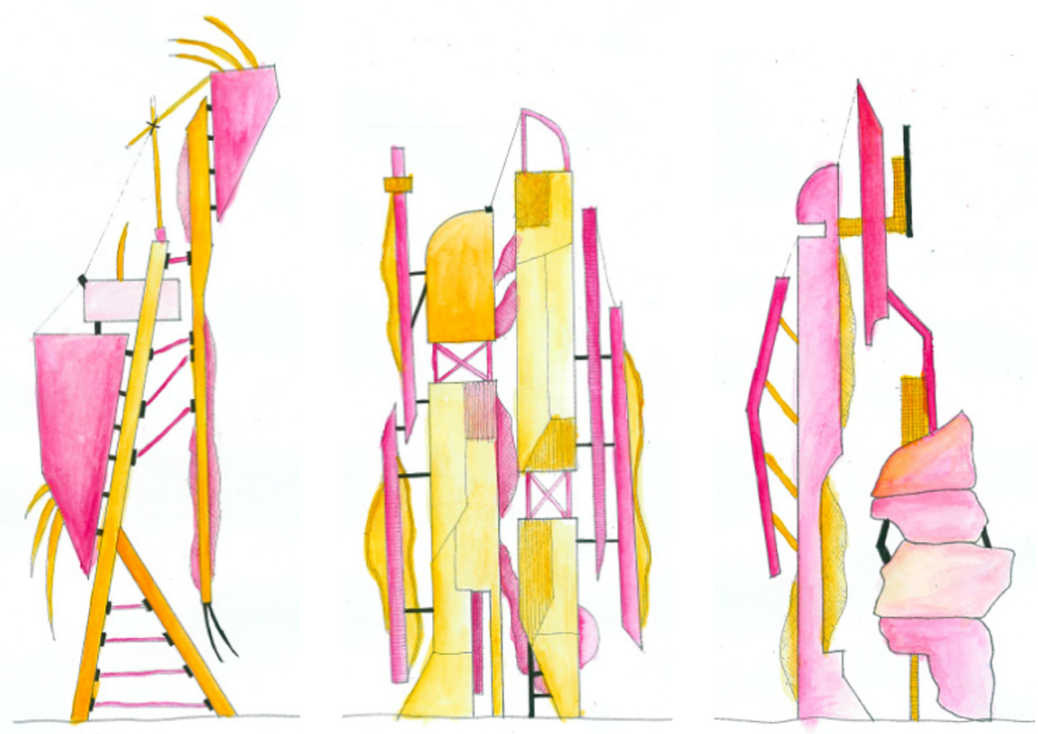
These sketches were the beginnings of the final Preliminary Design Phase. Unusual forms were attempting to be the opposite of traditional, and relate to theories from Woods, where letting go of traditional vernacular and becoming something new releases architectural baggage and preconceived ideas of a typology.

Program and site were not initially applied to these sketches as they were the first design wash and first attempt for what they were intending to achieve. However they resulted in a successful experiment as they led on to be developed as models with deeper meaning. 


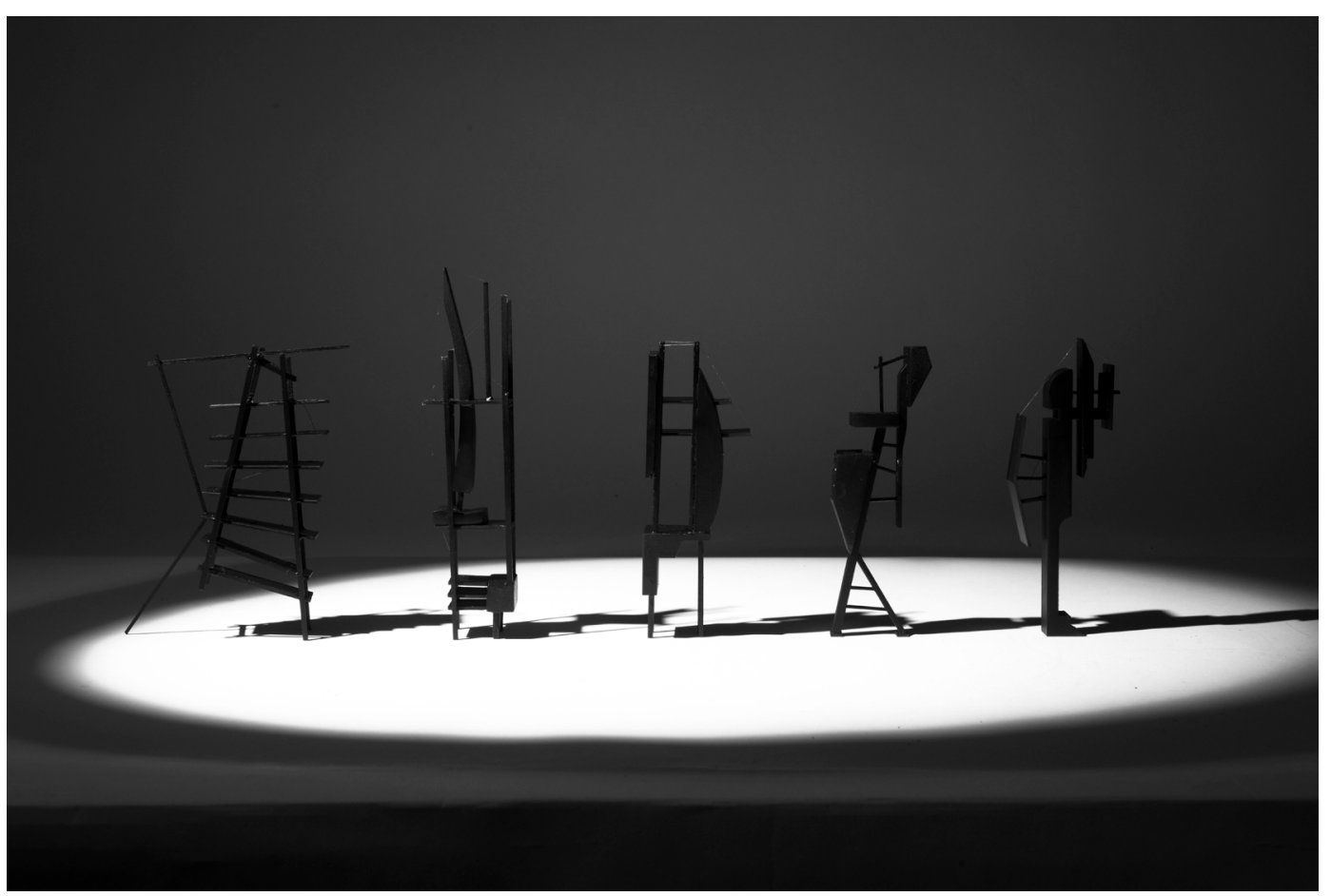

Figure 84 .

Observatory

models. 
These are the resulting observatories.

1 They are envisaged as being scattered across the city within or around the historic site to which they relate. They witness each other across the city from their individual sites, and respond to their site with their different symbolic persona.

Each design is very unique, but together they respond to the first objective of this thesis of being of speculative nature; the second as they tell the narrative of the particular site; the third as tell a narrative about the broken city of Palmyra; the fourth as they respond to contextual elements of place; and the fifth as they suggest inhabitation within their abstract, sculptural volumes.

The following pages detail each figure relative to their specific site and personality. 


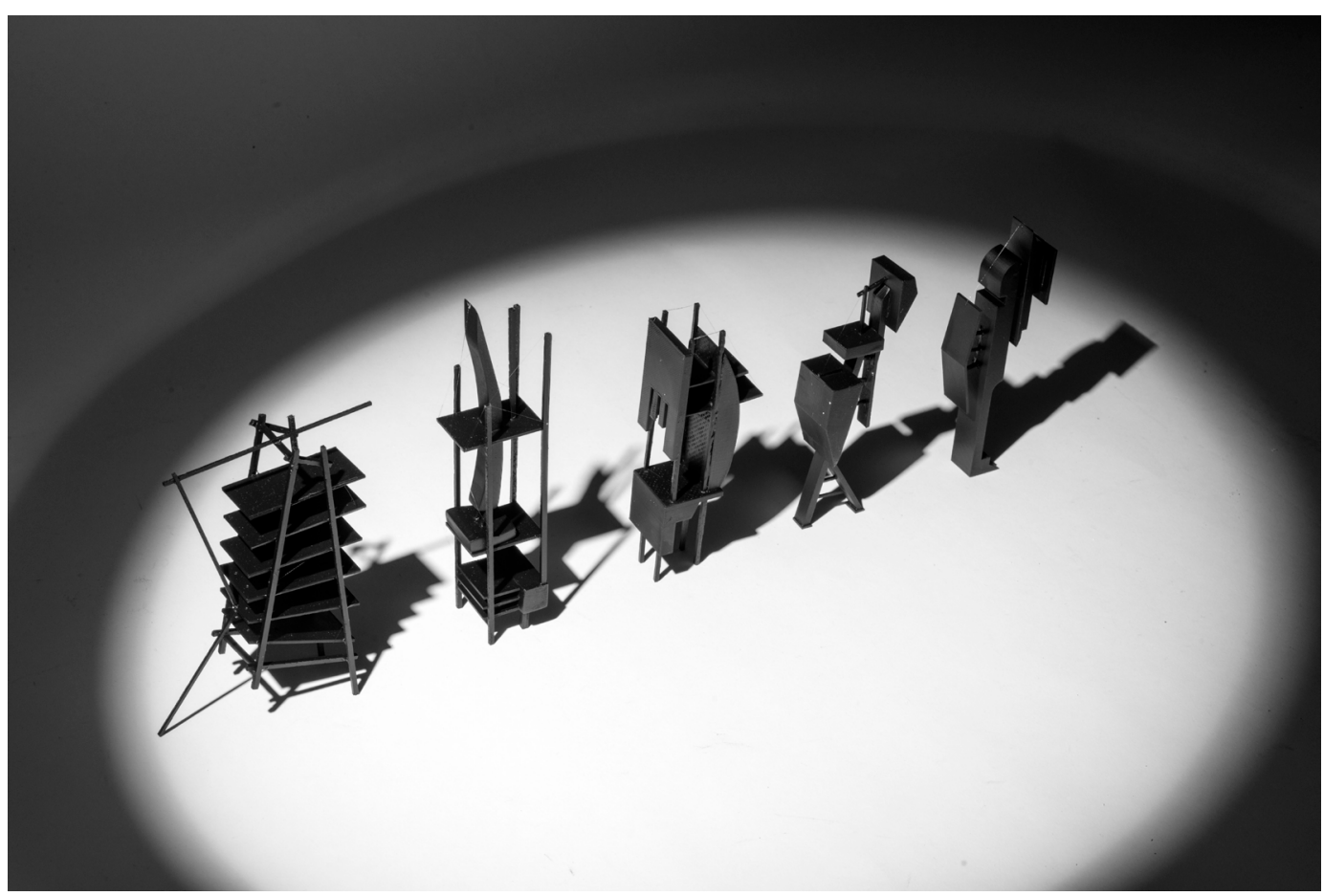

Figure 85.

Observatory

models. 


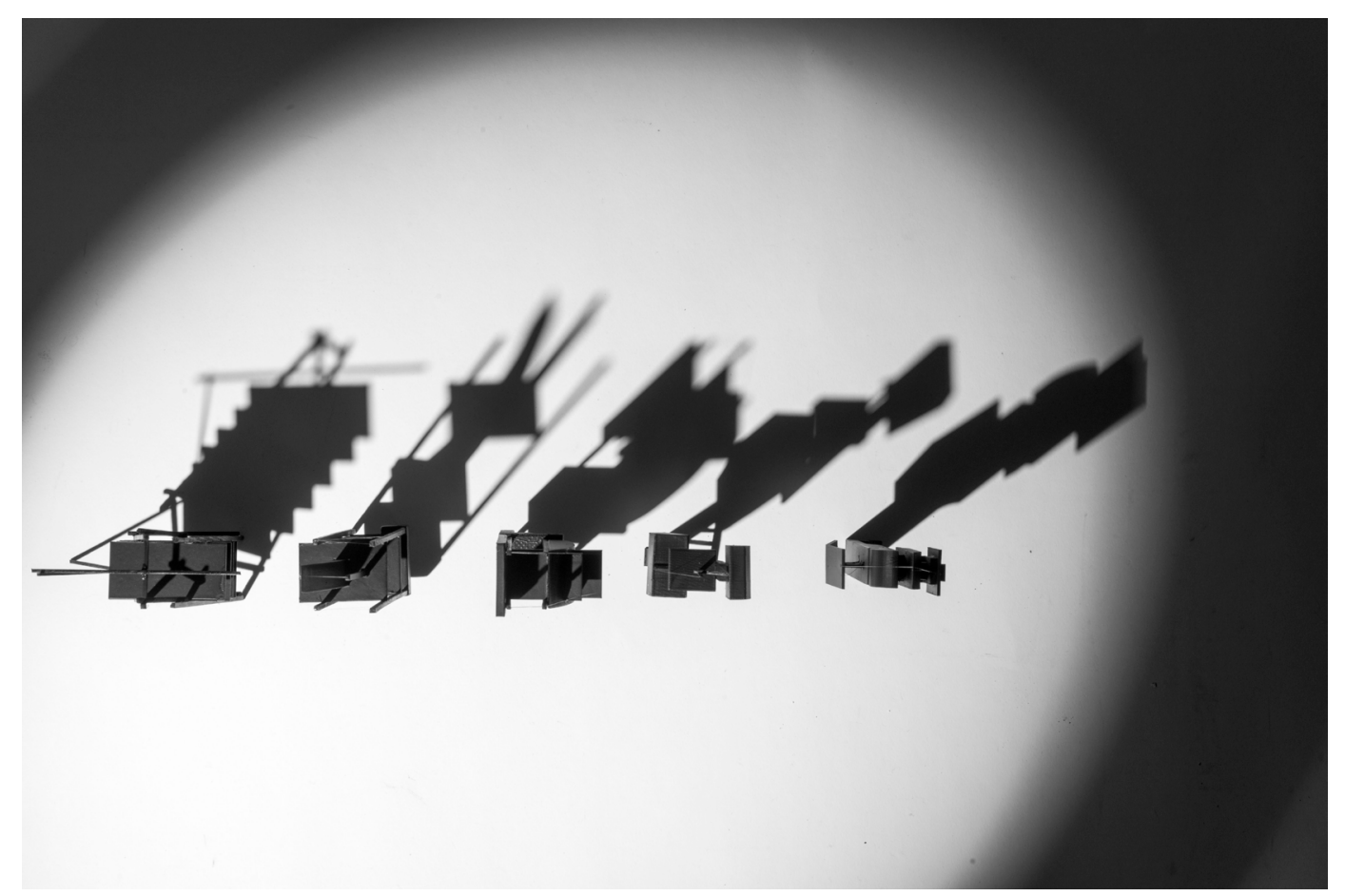

Observatory models. 


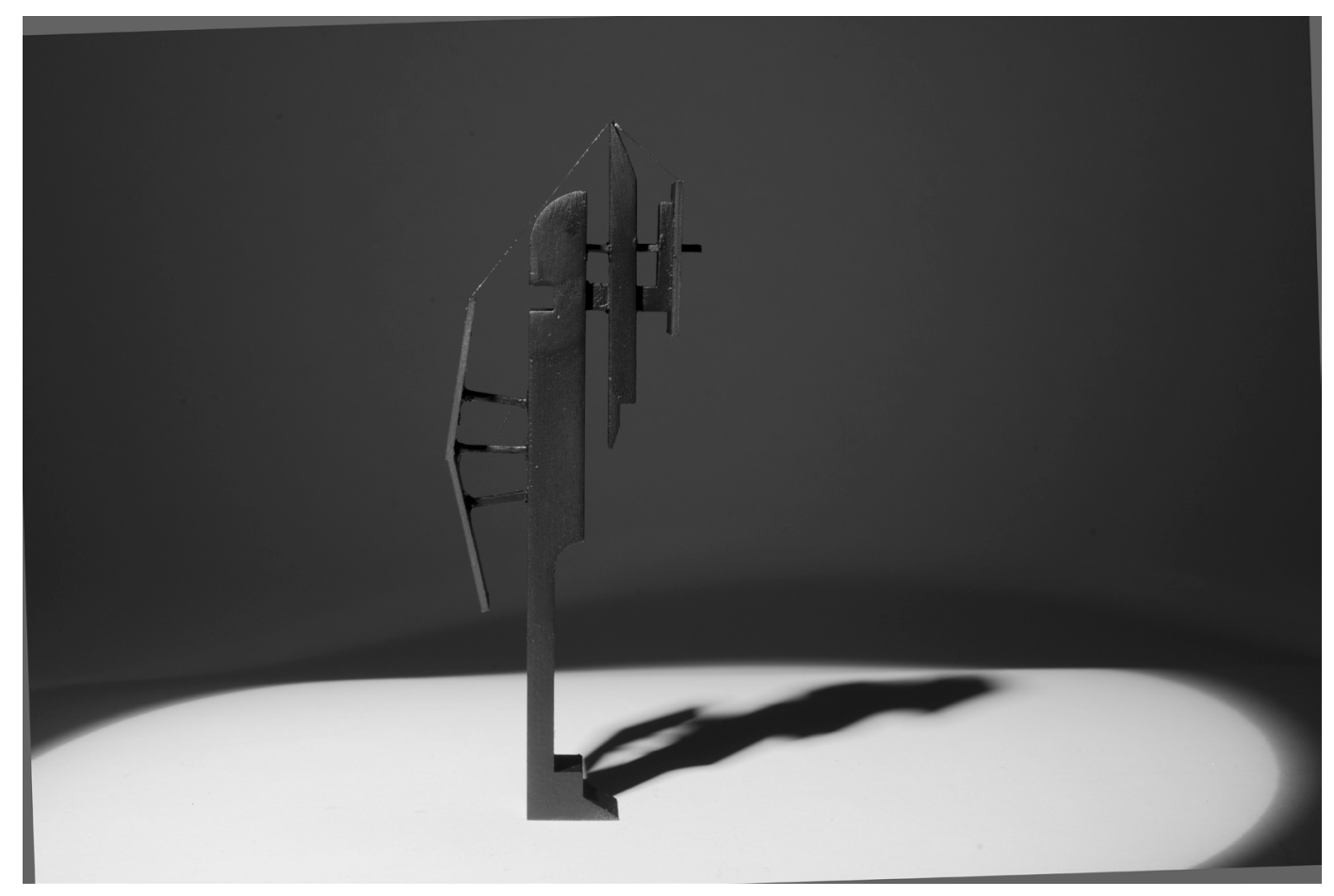

Figure 87.

Prison 1.

Model.

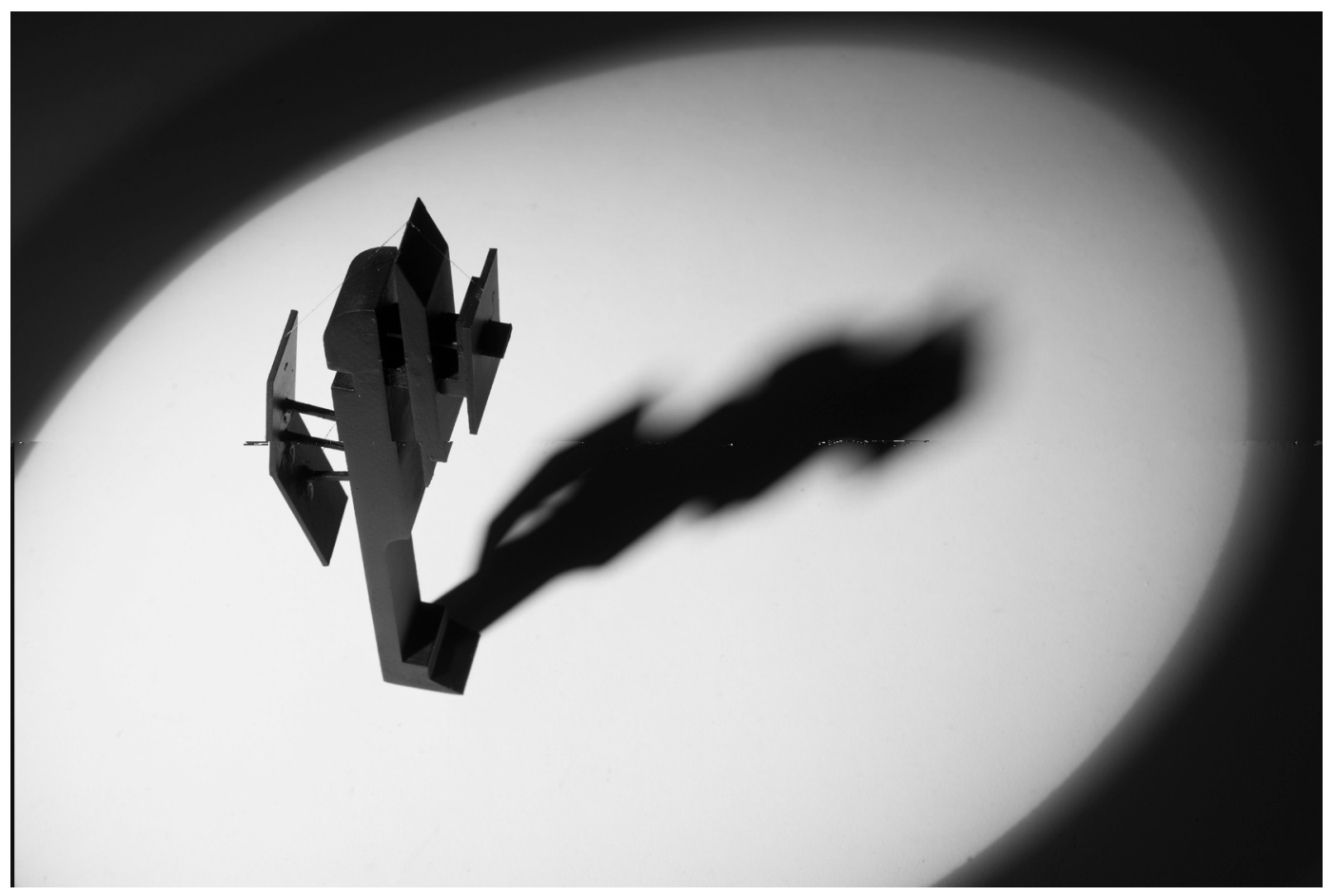

Figure 88

Prison 1.

Model. 


\section{PRISON 1}

Symbolic of the Tadmor Prison, showing elements of repetition of bars, rigidity, anonymity, separation. Positive and negative volumes with the main volumes being separated above ground and by hostile walls. 


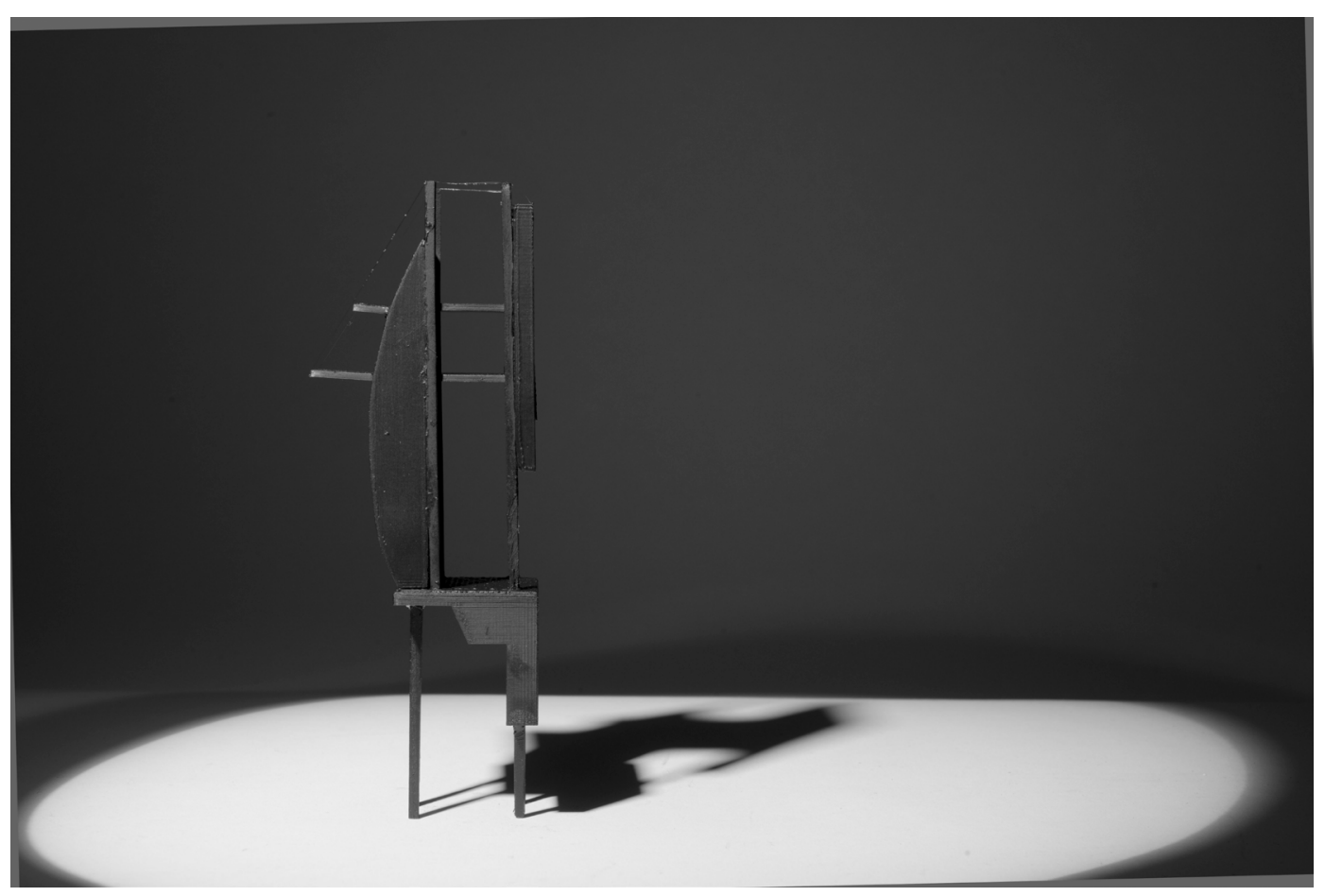

Figure 89.

Prison 2.

Model

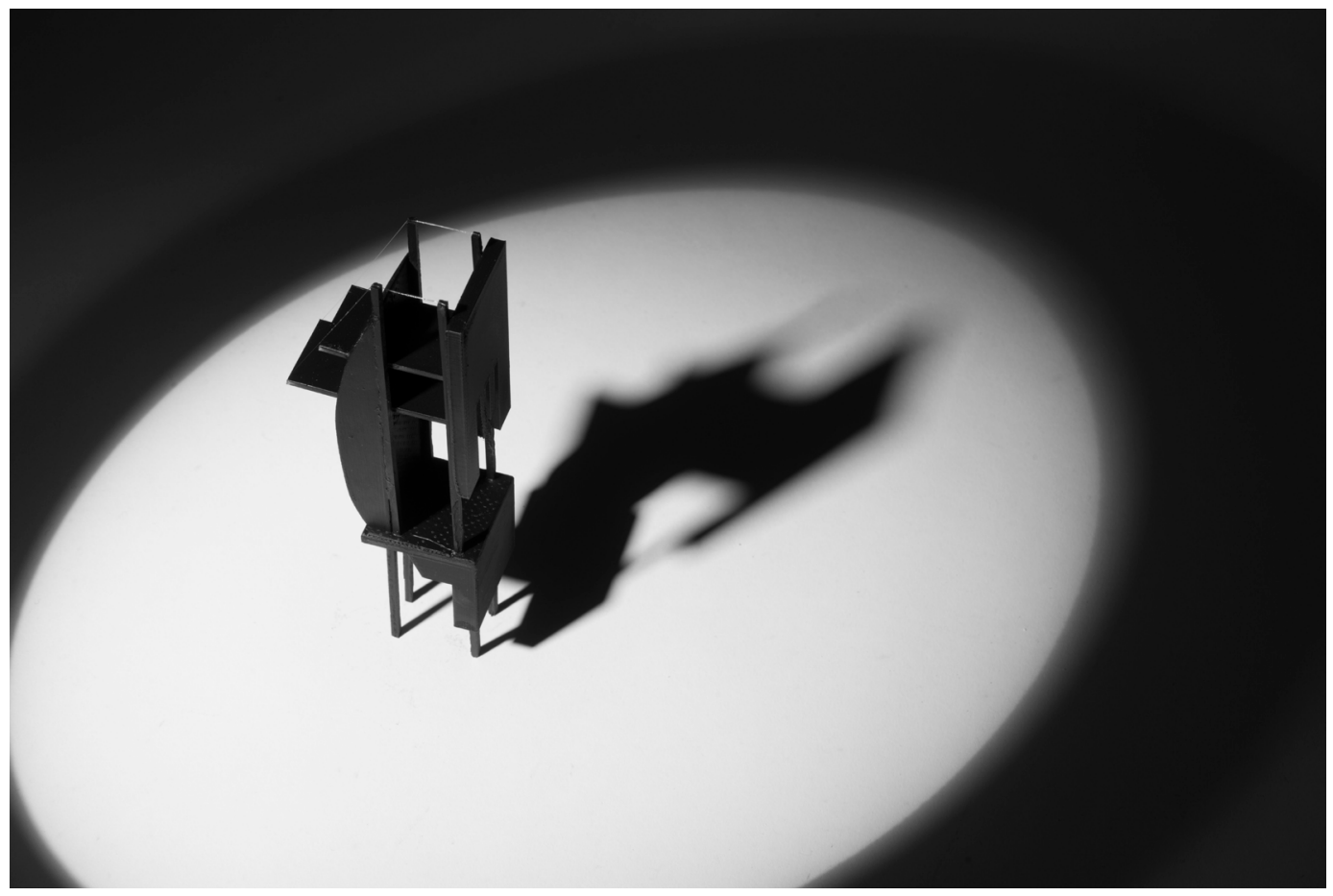

Figure 90.

Prison 2.

Model 


\section{PRISON 2}

Symbolic of the Tadmor Prison, showing elements of repetition, rigidity, anonymity, separation. Rigid structures with main volumes being stuck and restricted from movement. 


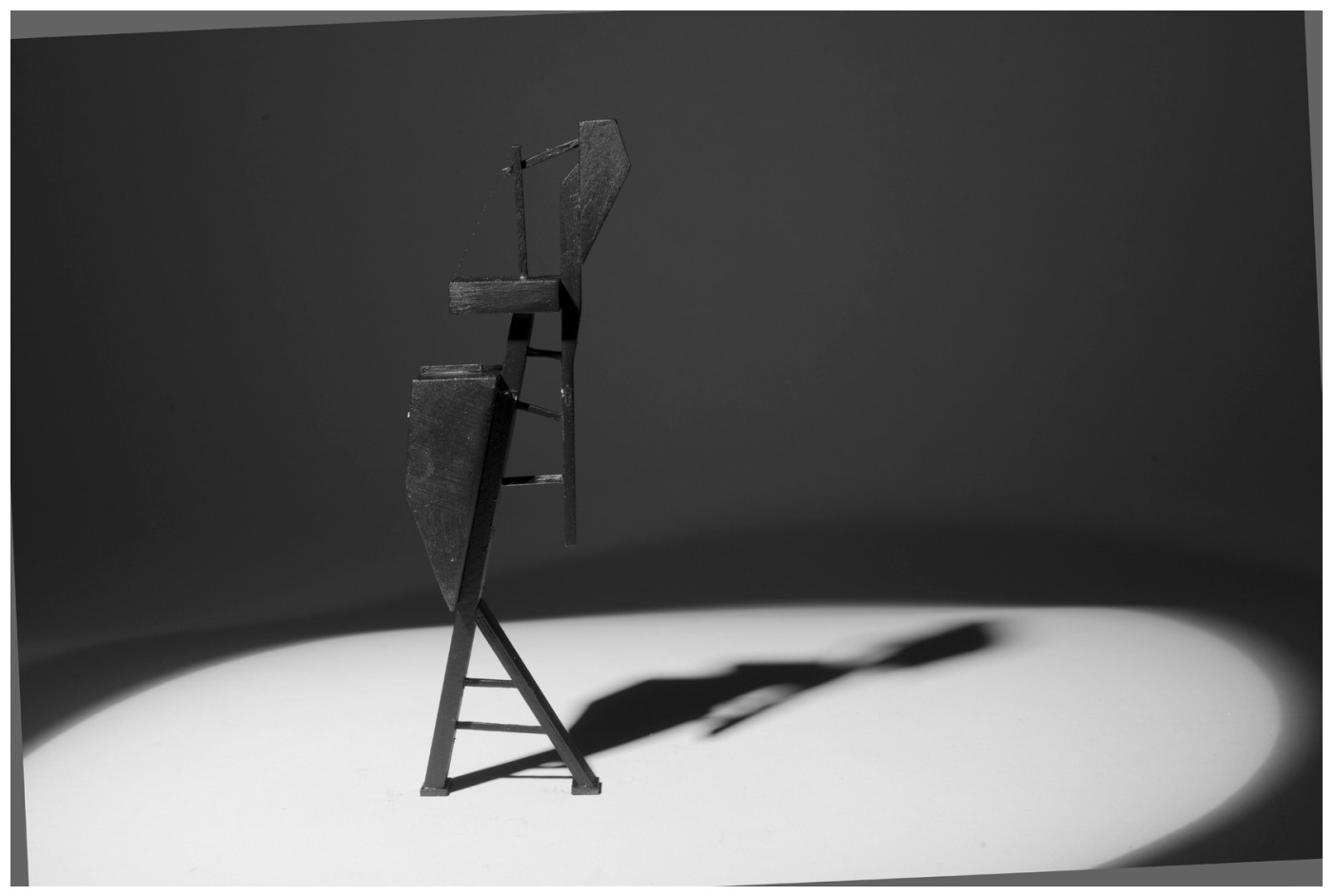

Figure 91.

Camel racing

track 1. Model.

Figure 92.

Camel racing

track 1. Model. 


\section{CAMEL TRACK 1}

Symbolic of the community camel racing track, showing elements of playfulness, recreation and freedom as it is leaning forward, it has torsion and wants to be moving. 


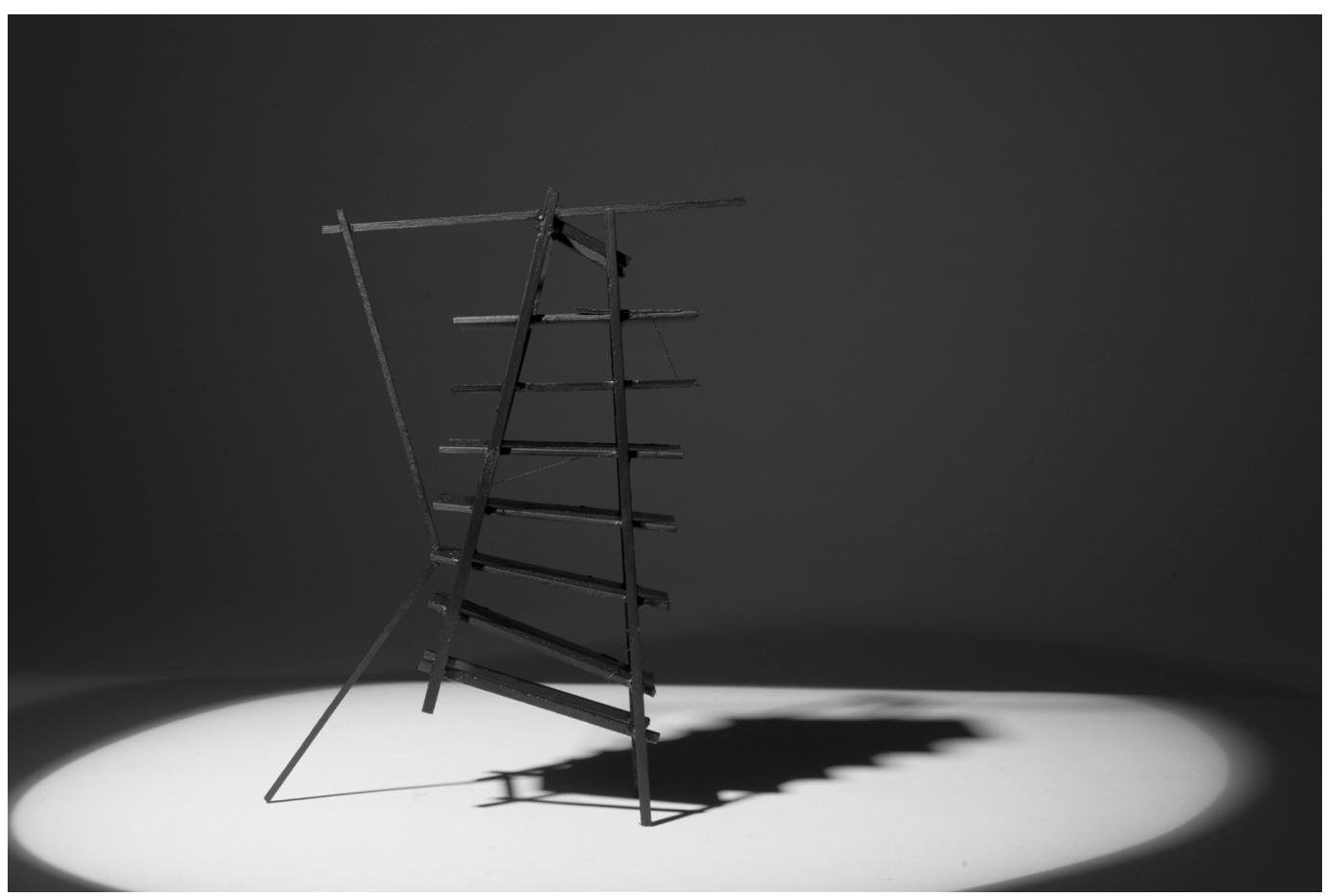

Figure 93.

Ancient city 1 .

Model.

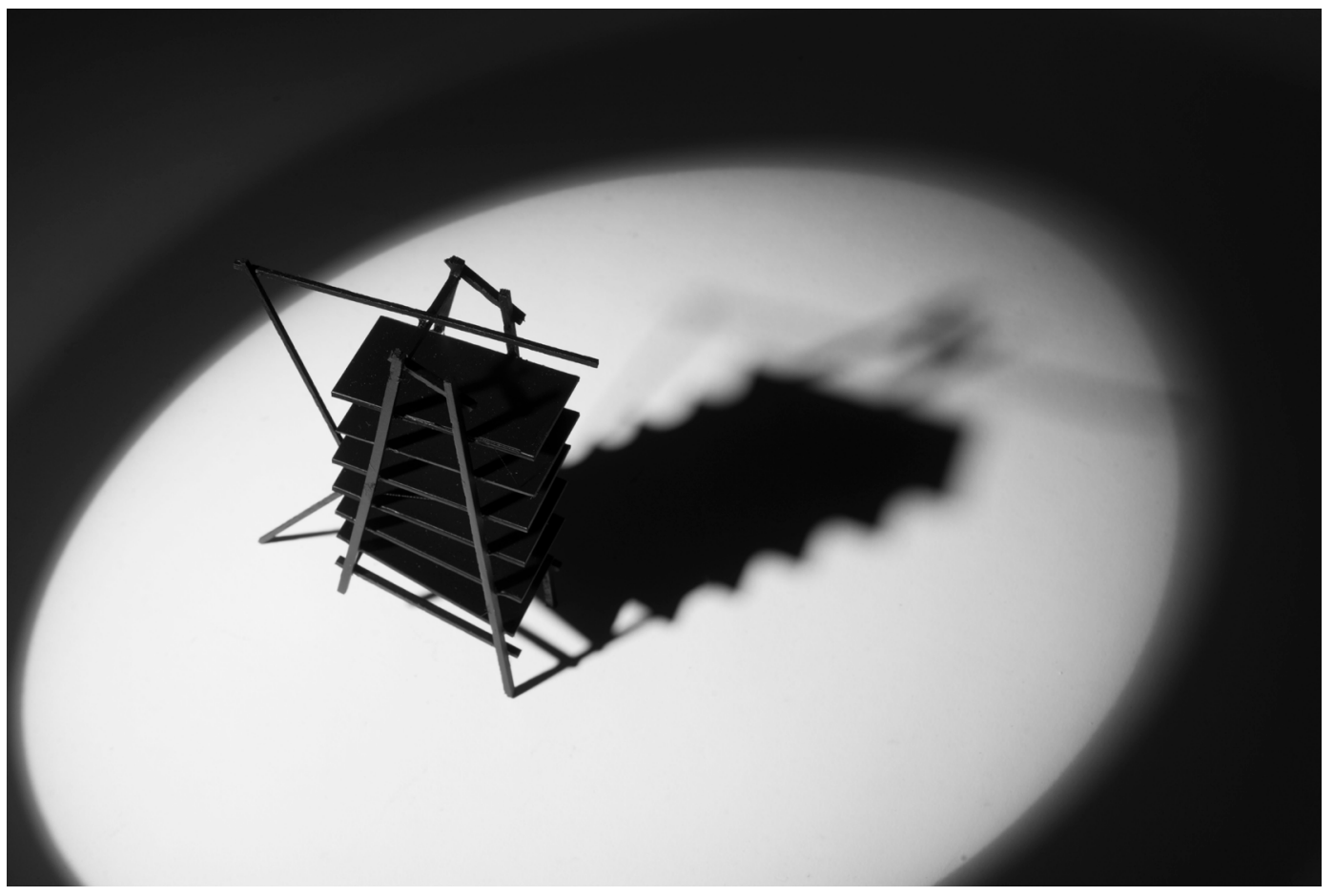

Figure 94.

Ancient city 1. Model. 


\section{ANCIENT CITY 1}

Symbolic of the ancient city and its rich history. A series of excavated layers extruding up and out of the ground plane supported by vertical members that encapsulate and hold the layers. 


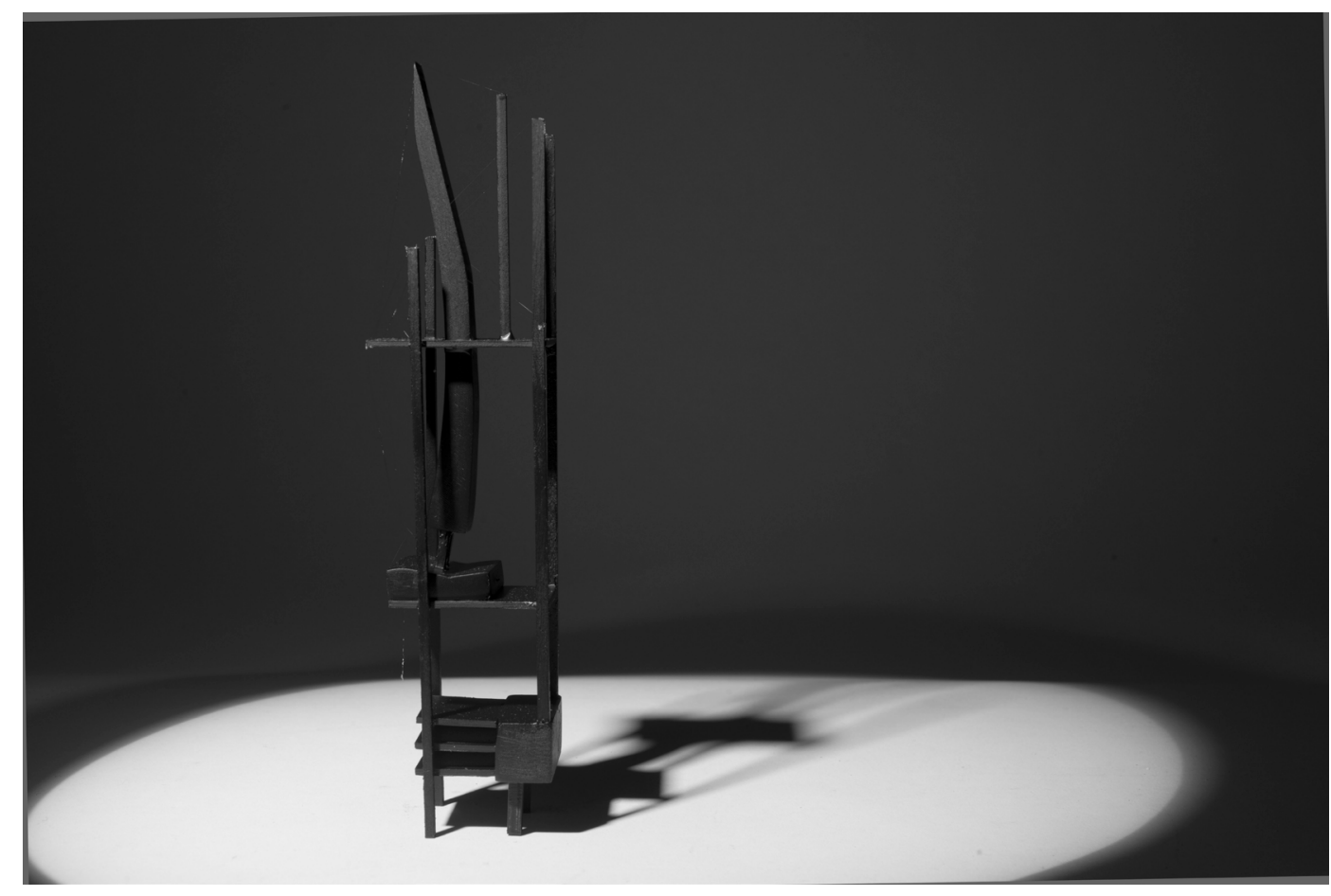

Figure 95.

Ancient city 2.

Model.

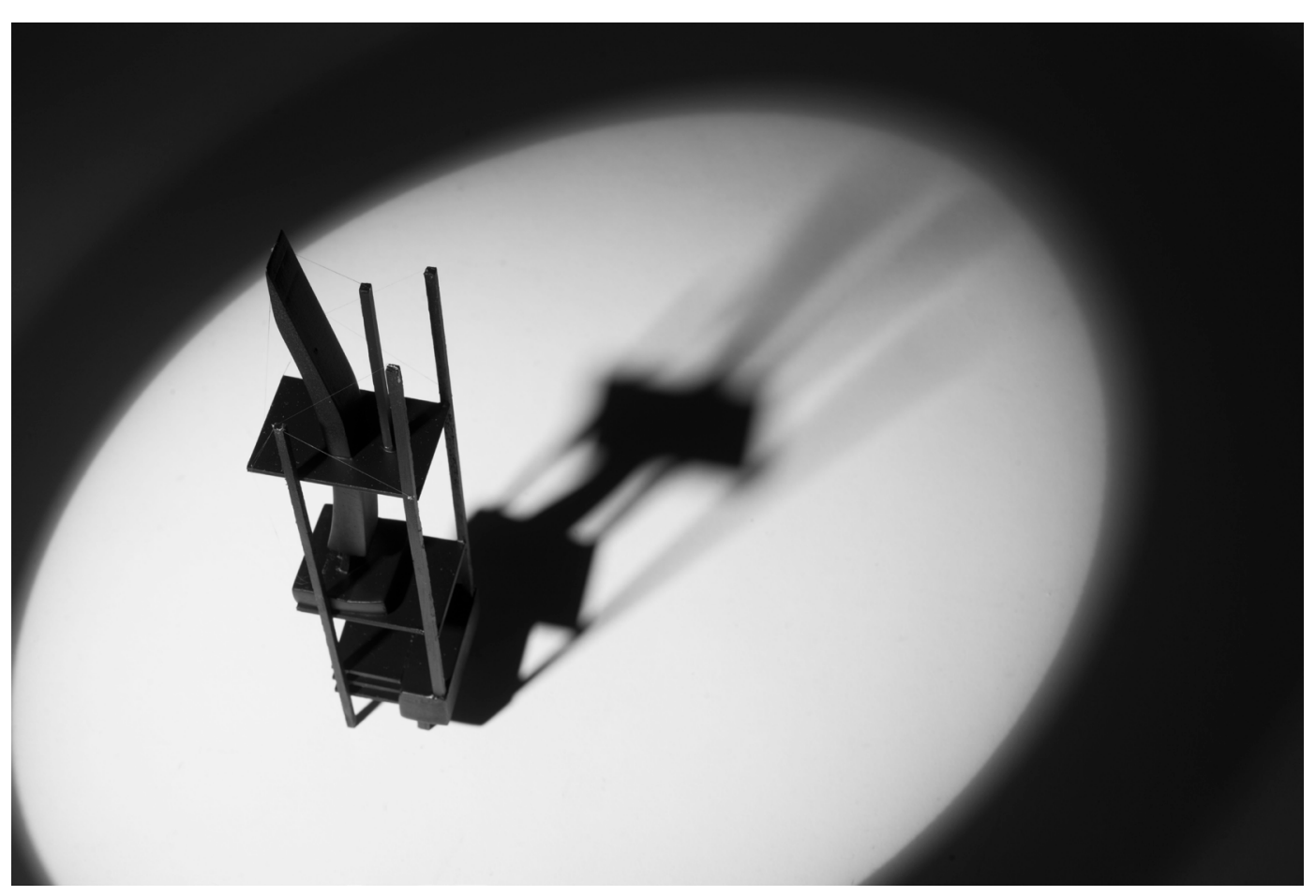

Figure 96.

Ancient city 2.

Model. 


\section{ANCIENT CITY 2}

Symbolic of the ancient city and its rich history. A series of excavated layers extruding up and out of the ground plane with volumes and vertical elements intersecting and balancing the historic contents. 
This chapter presented the iterative design 1 approach for this design-led research investigation, which was essential to enabling the following final design to be realized.

Each phase of this process was critiqued in relation to the aims and objectives of this thesis, and to the findings in the preceding chapters. For example, even though a great deal of process work had occurred to arrive at the concept designs, there were still elements from site analysis and the literature review that needed to be included to create a strong argument and design, so I had to regularly revisit these chapters in order to move forward.

The findings from the preceding chapters have provided a tool box to forge a final design solution for this design-led research experiment. 

06

\section{DEVELOPED DESIGN}

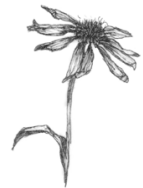




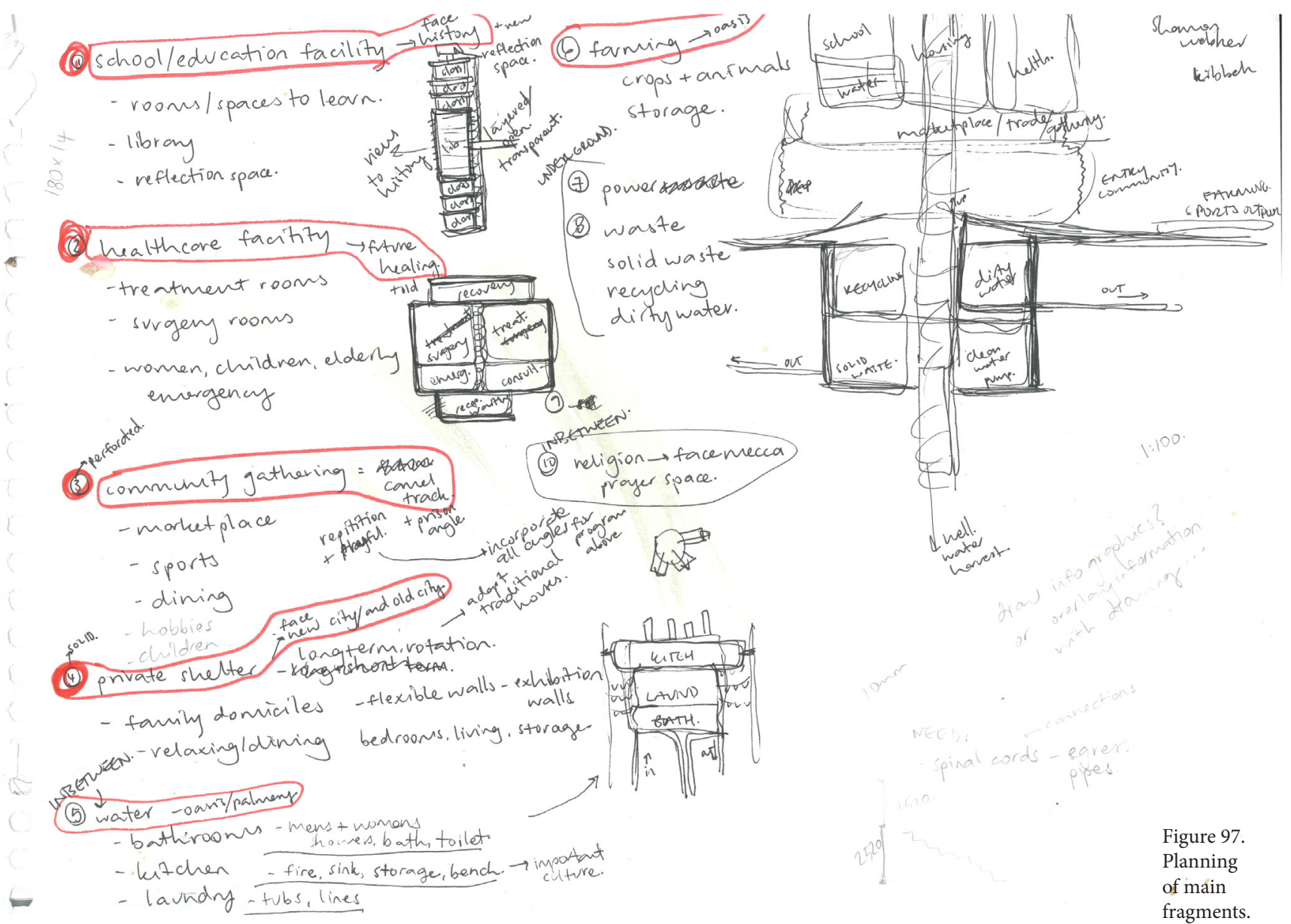

The image above shows the raw process that was involved in the beginning of this phase. The grouping of important elements from preceding chapters with design experiments to be able piece together a final design solution. 
7 his chapter presents and critically discusses the final design outcome for this design-led research experiment. The aim of this concluding design experiment is to establish not a refugee centre, but a kind of metaphorical 'sanctuary' temporary shelter that a community can live in whilst awaiting the construction of new housing. A sanctuary where the returning community can feel safe once they return home to their ravaged city after the war.

The research question that the final design experiment is addressing is "What role can architecture play in restoring the identity of a historic town after a traumatic disaster?" The objectives that this final solution will be achieving are; the proposition of a speculative scheme that will not be built, but act as a catalyst for the future of Palmyra; the use of architectural narrative to tell a story about the broken, historic city; the blending of realms between landscape and architecture, with bold forms with strong light and shadow; the creation of nontraditional forms; and expression of form and concept through drawing, sculpture and architecture.

The following pages present each fragment of the final design, and describe the contents of each and how they achieve the aims and objectives of this investigation. 

7 he design responds initially to the and then later when not used it will become an archive/museum/memorial that invites the people to remember, educating the next generations to come.

The building itself becomes the museum, through fragments and pieces of the old town that have been included in the construction, embedded in the walls and floors - so history is all around them, and when everyone has moved out, other artefacts can be brought in. As well as provide views to reflect on the identity and history of their home.

Figure 98 shows the first sketch and first attempt at constructing the final design. The first attempt at putting fragments of the puzzle together. The general arrangement of volumes was successful and set the scene for the following design. 


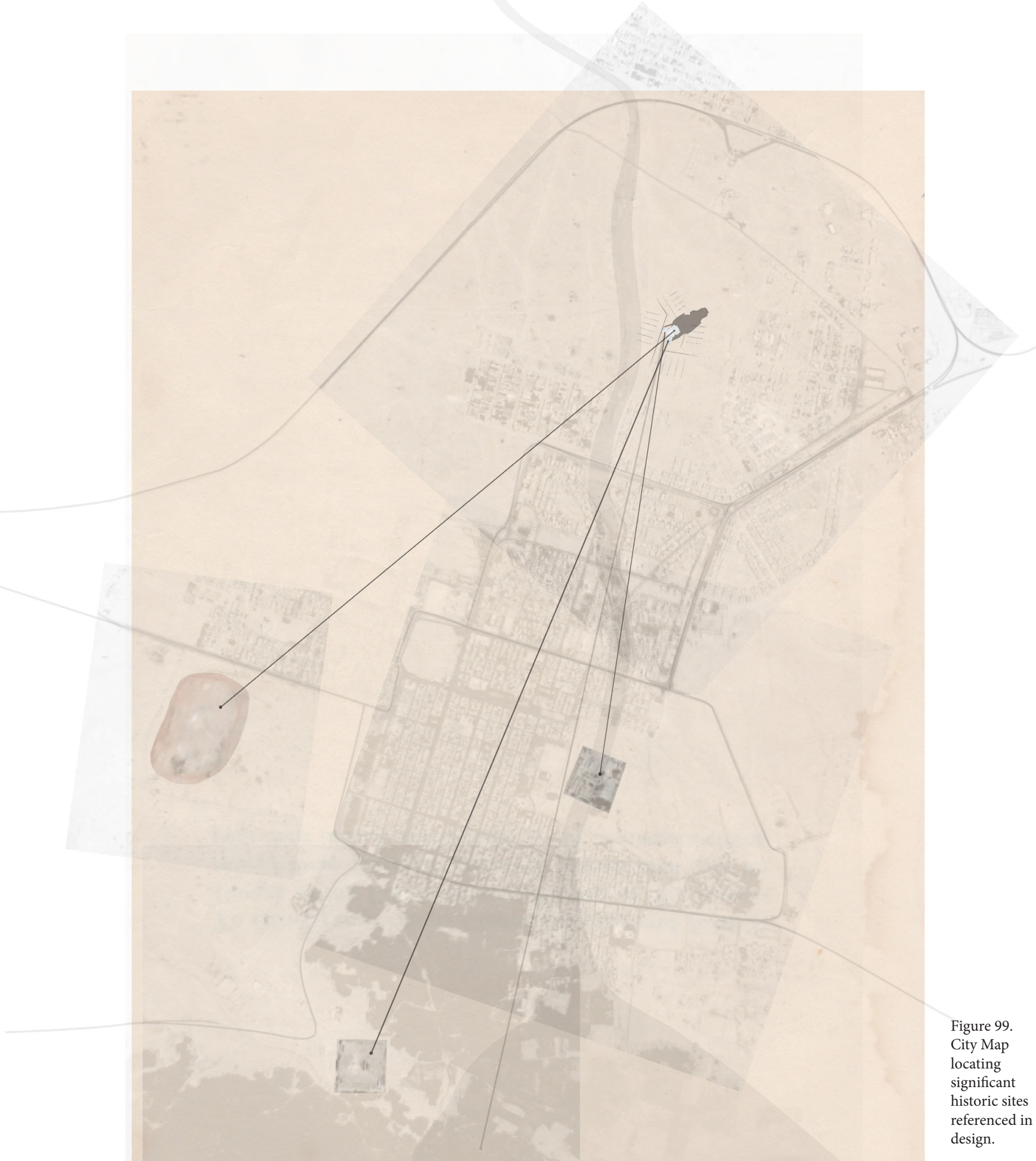

$25 \mathrm{~km}$

(a) 


\section{LOCATION}

The three important historic sites that were identified in the site analysis chapter are referenced by three fragments that face each site, providing important vistas and views of each for the inhabitants.

Figure 99 shows the three sites in the city and the angle that each fragment must be on. 


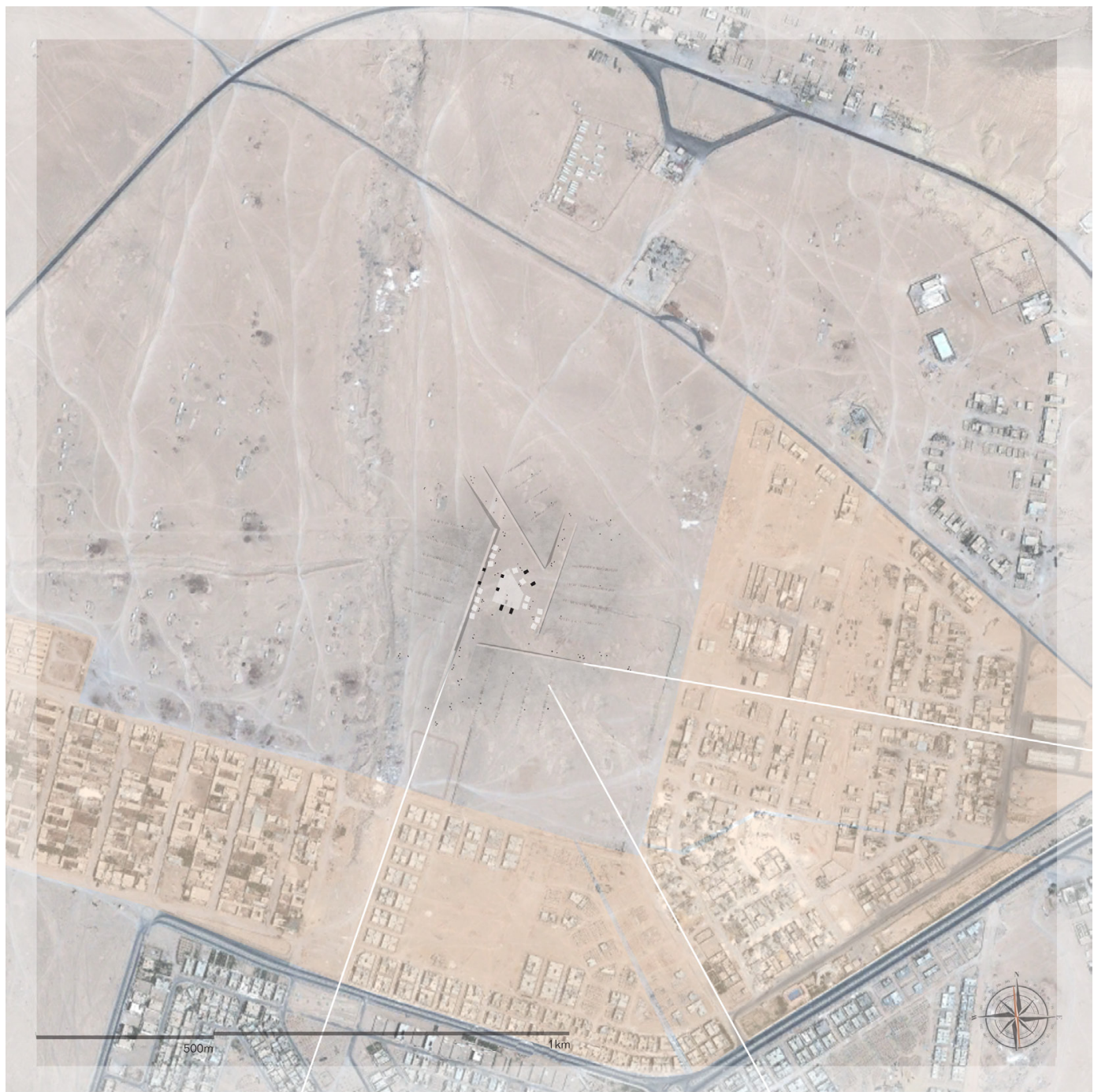

Figure 100. Site

plan. Ground

floor (entry). 


\section{ROOTS}

The roots of the building provide four inhabitants, with each arm informed by an axis found within the immediate landscape. These three main axis are based upon the existing urban grids identified in the site analysis chapter, as the building is located at the apex of the three. This design decision provides a grounding within the immediate context, and as you travel vertically through the building, the spaces begin to reference the three historic sites.

The design decisions for the base of the building respond to the theories and work of Mary Miss where bold forms cut through the natural landscape, these short walls that slice through the earth result in a subtle blending between the landscape and architecture. The contrast between the straight clean forms against the shallow ravines and road forms is also evidenced in this plan. 


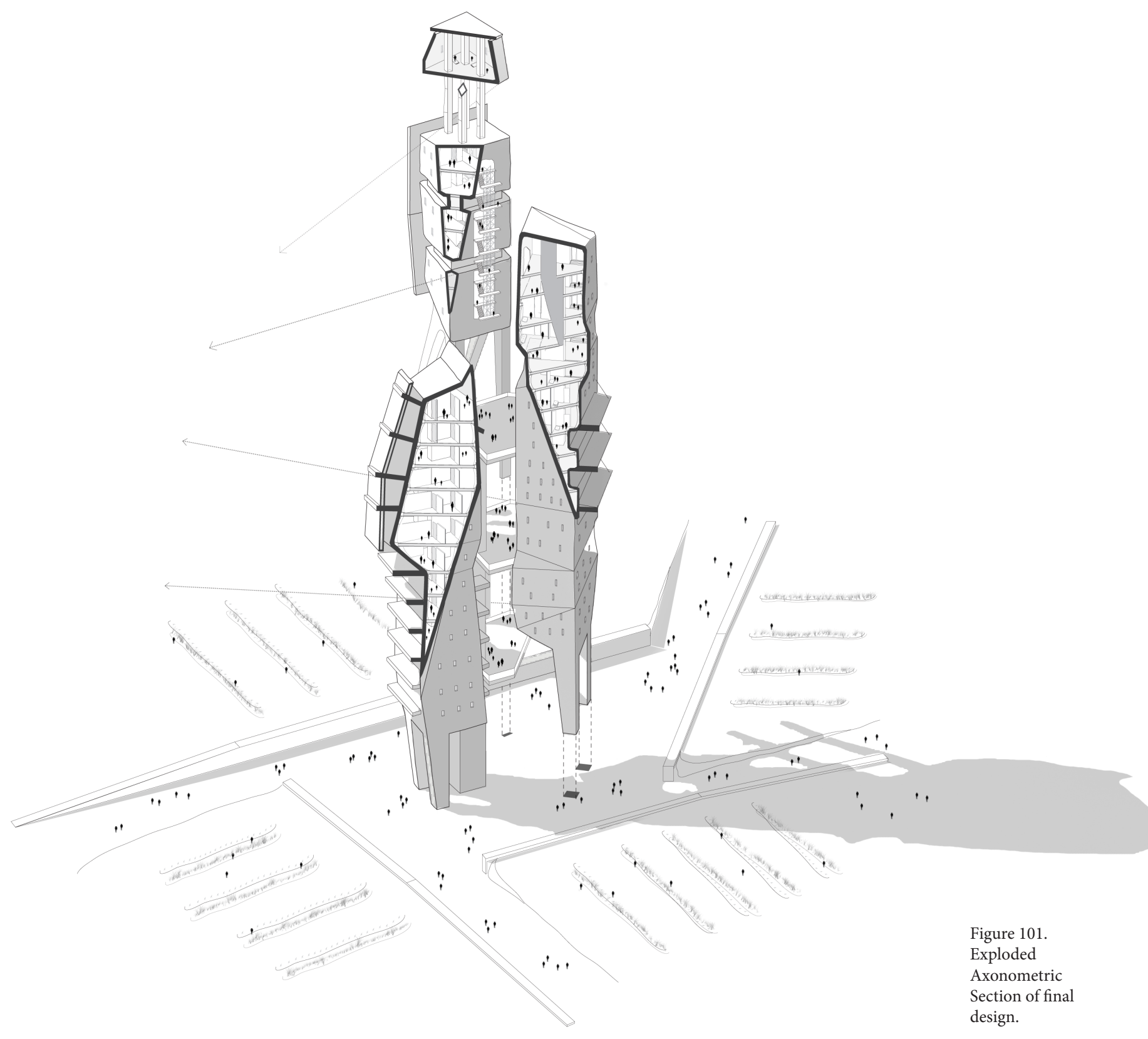




\section{A FRAMEWORK OF TIME}

Zigure 101 shows an exploded axonometric of all three fragments on their site. The design consists of three main fragments that hold the elements needed for life when the refugees return, there are: spaces for nourishment, shelter, gather, repair, learn and reflect which are shown in detail later.

Within each of the three fragments there are one or two of these elements based upon the direction and historic site that fragment is facing. For example: one holds shelter and gathering spaces, one holds nourishment and reflection spaces, one holds learning and repair spaces.

The building as a whole tells a story about the broken city of Palmyra, as each tells the story of the important site it faces, responding to the second objective of this research investigation.

The following pages describe each of the three fragments and explain why design decisions were made, as well as critically reflect upon their success in relation to the aims and objectives of the research investigation. 


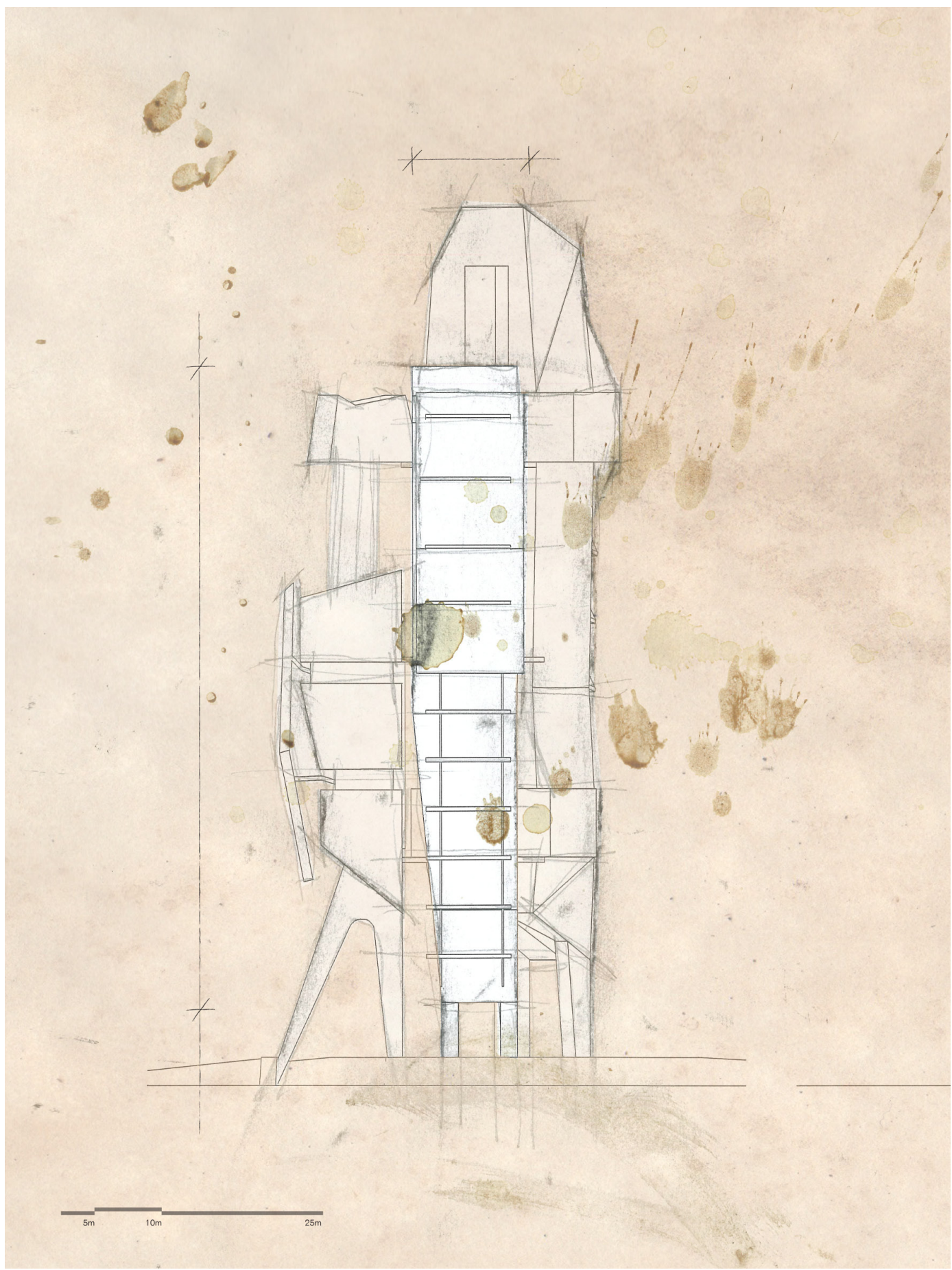

Figure 102

Fragment

1. Learning and Repair. Elevation. 
FRAGMENT 1

LEARNING AND REPAIR 

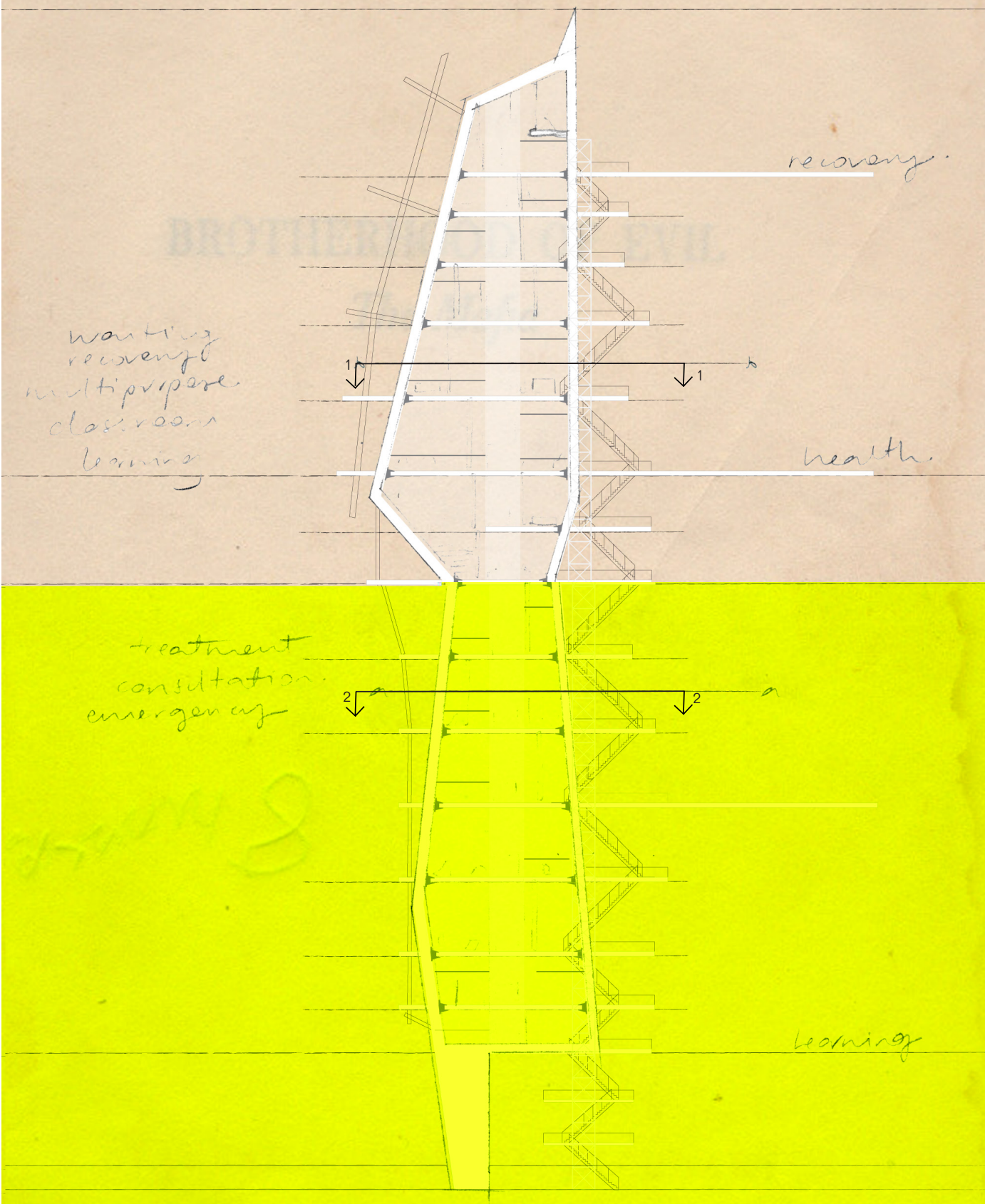

Figure 103.

Fragment 1.

Learning and

Repair. Section AA. 


\section{SECTION}

This fragment offers spaces to learn and

1 to repair through health care services and education services. All fragments have a similar construction with a central core structure (shear walls) that provides people with the basic services of a toilet and kitchenette. On the inner side (right) it meets outdoor community levels in three places, where the stairs and lift is also located.

The spaces within this fragment both face the ancient city, allowing the inhabitants to look back and learn about or reflect upon the past, and to repair through this reflection.

This fragment successfully achieves the aims and objectives of this investigation as the design decisions for this fragment embody the cultural past, and offer the opportunity to learn about the rich history and identity of place through the architectural narrative. The form is also not traditional 


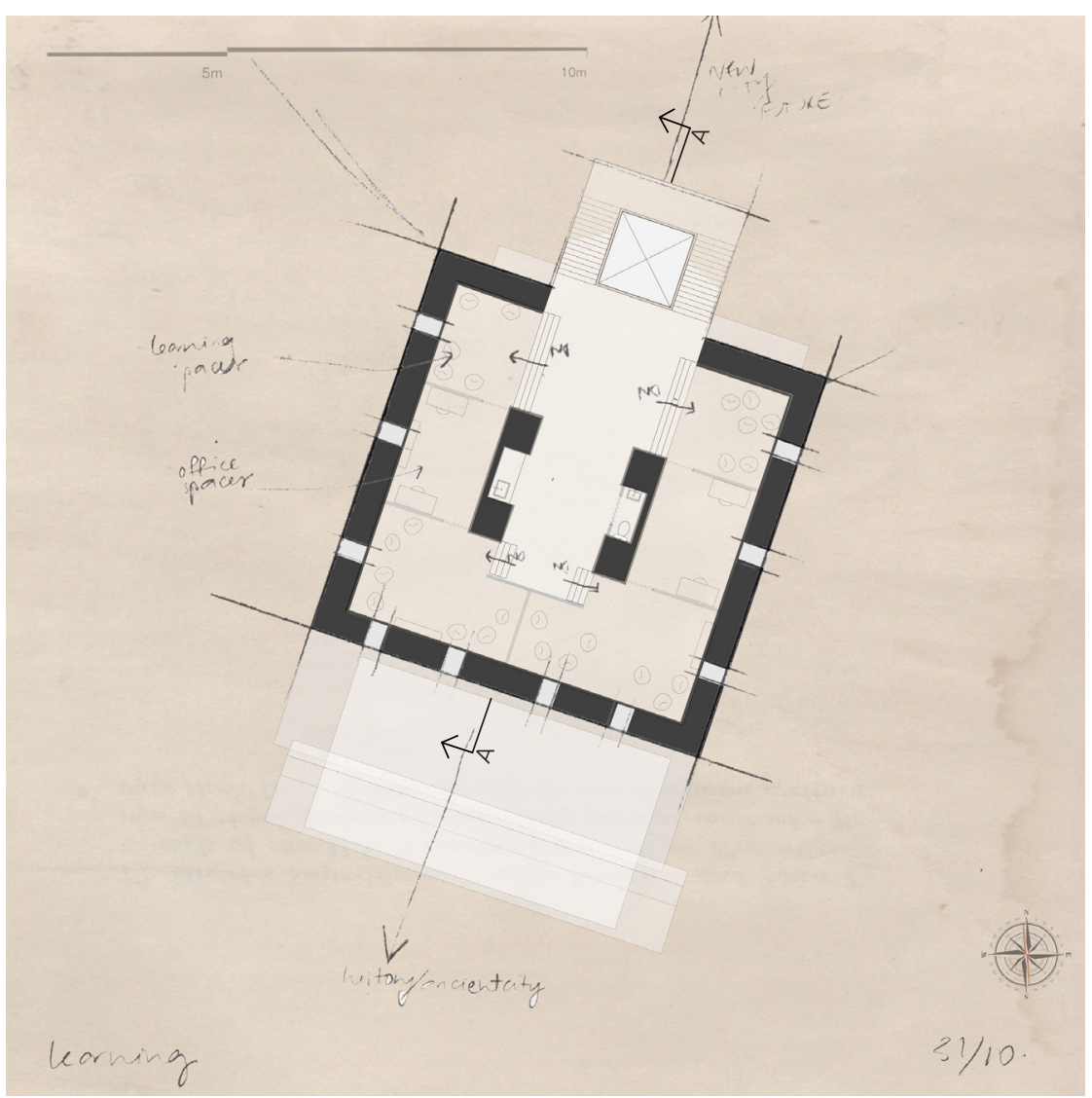

Figure 104.

Fragment

1. Learning

Plan 1.

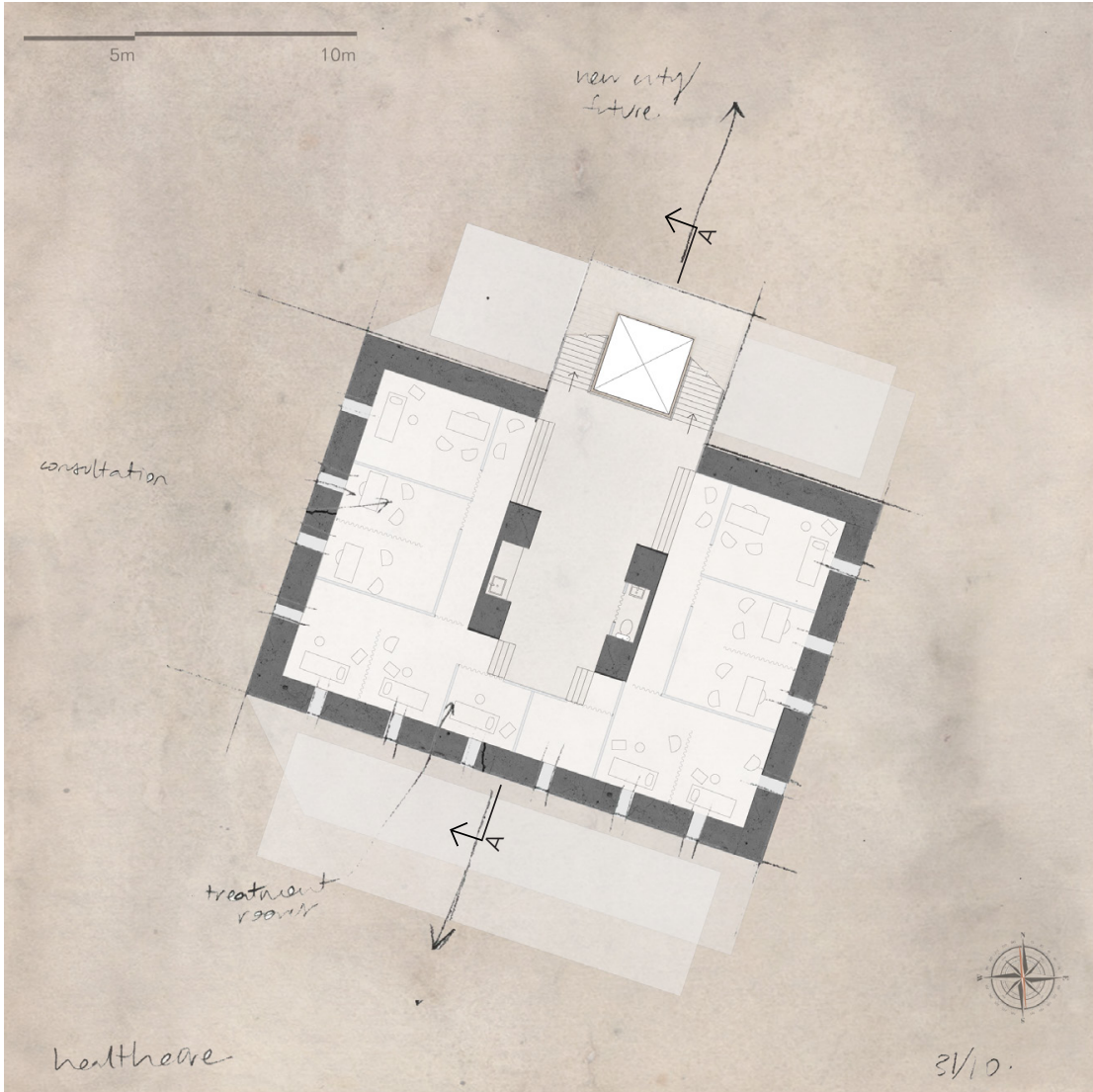

Figure 105.

Fragment 1.

Repair. Plan 2. 
The interior floor plans are very open,

1 with services that are held within a core (shear walls) that permeate the entire building. There are communal spaces in the centre of the fragment and around the edge are private spaces of varying sizes to reference the plan of the caravanserai analysed in the site analysis chapter.

The plan shows a contrast between thicker permanent exterior walls with thin internal moveable walls to reference the plan of a caravanserai, and the contrasting materials used in the Temple of Bel. 


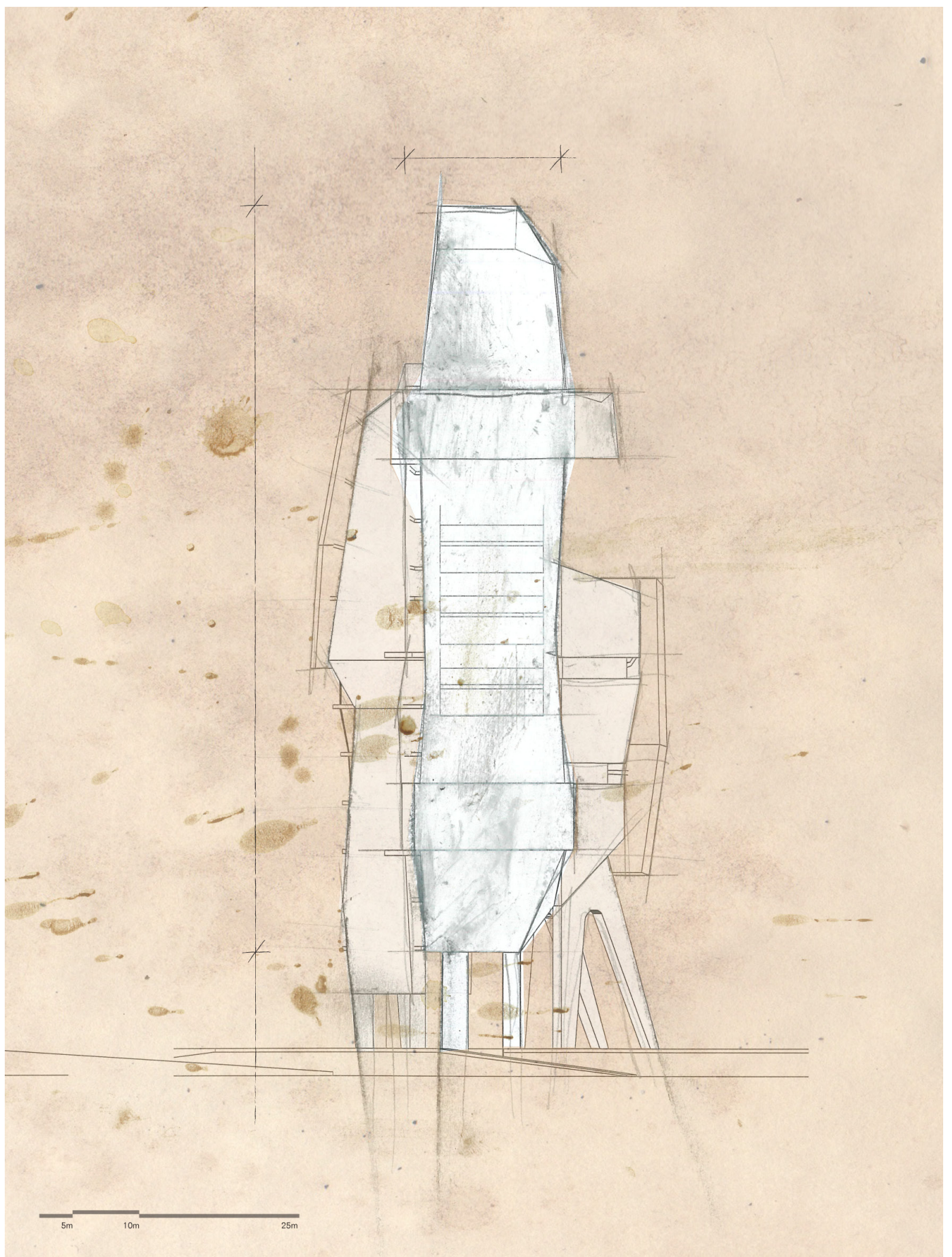

Figure 106.

Fragment 2 .

Shelter and

Community.

Elevation. 
FRAGMENT 2

SHELTER AND COMMUNITY 


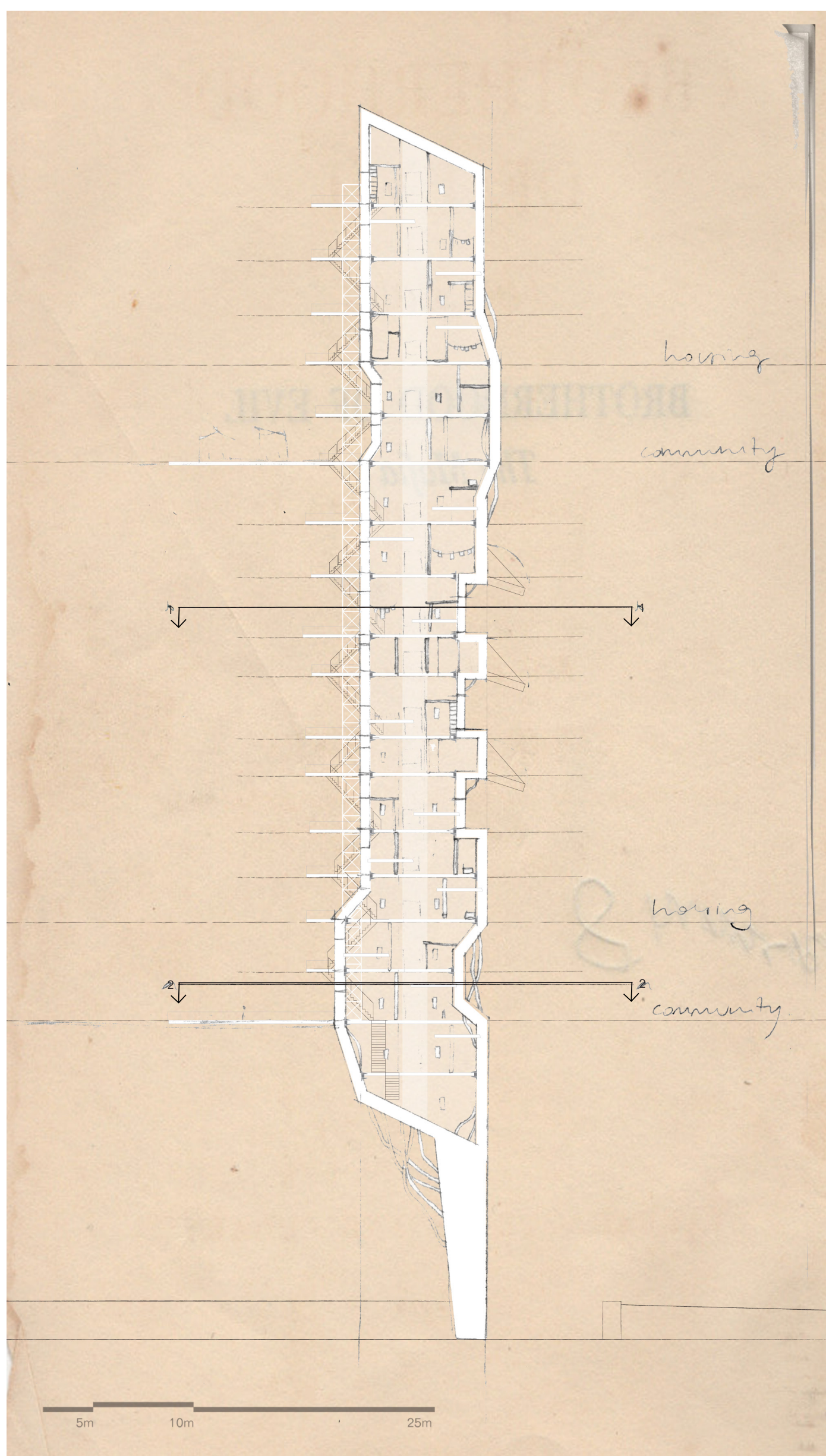

Figure 107.

Fragment 2 .

Shelter and

Community.

Section AA. 


\section{SECTION}

The second fragment provides spaces for 1 shelter and community gathering. In this fragment the space for shelter faces future development to remind the inhabitants of hope and the future chapters of Palmyra that are to come. The community gathering spaces face the camel track to remind them of recreation and freedom. Because there are two types of space in this fragment and they each face different sites, there are two twists in the body. This design decision results in non-traditional form informed by the site.

This fragment also has a central core (shear walls) structure that provide basic services of toilet and kitchenette on every floor. On the inner face (left) the body meets the outdoor community levels in two places - allowing the indoor community spaces to flow and join these. The the stair and lift are also located on this inside face.

The fragment is successful in answering the aims and objectives of the research investigation as the design decisions described above tell a narrative through the architecture by looking to important cultural sites throughout the city - specifically the camel racing track and the future development, embodying the cultural future. 


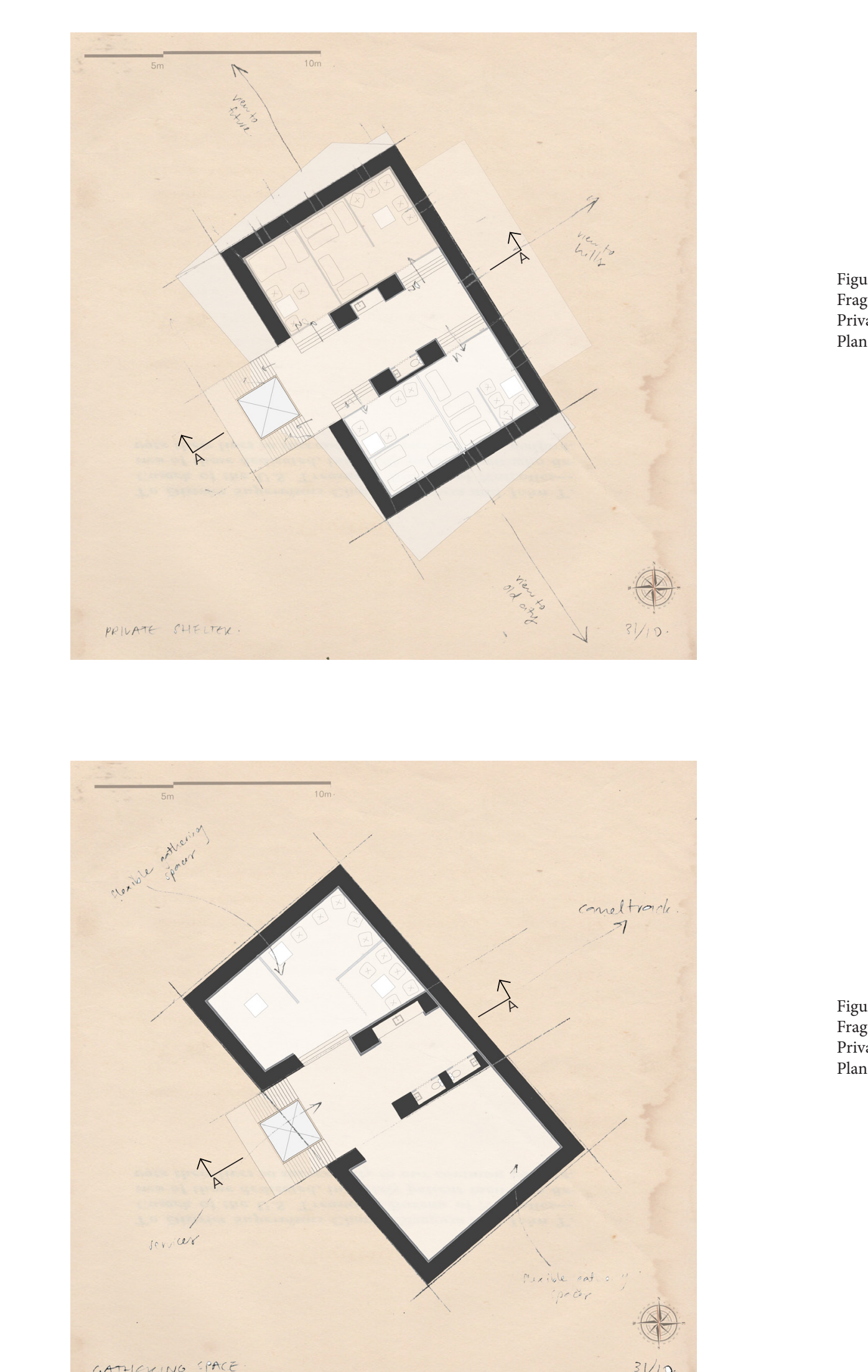


The interior floor plans of this fragment are 1 also very open, with services that are held within a core (shear walls) that permeate the entire building. There are communal spaces in the centre of the fragment and around the edge are private spaces of varying sizes to reference the plan of the caravanserai analysed in the site analysis chapter.

The plan shows a contrast between thicker permanent exterior walls with thin internal moveable walls to reference the plan of a caravanserai, and the contrasting materials used in the Temple of Bel. This design decision relates to the aims and objectives by referencing the cultural past, and also a blending of the architecture. 


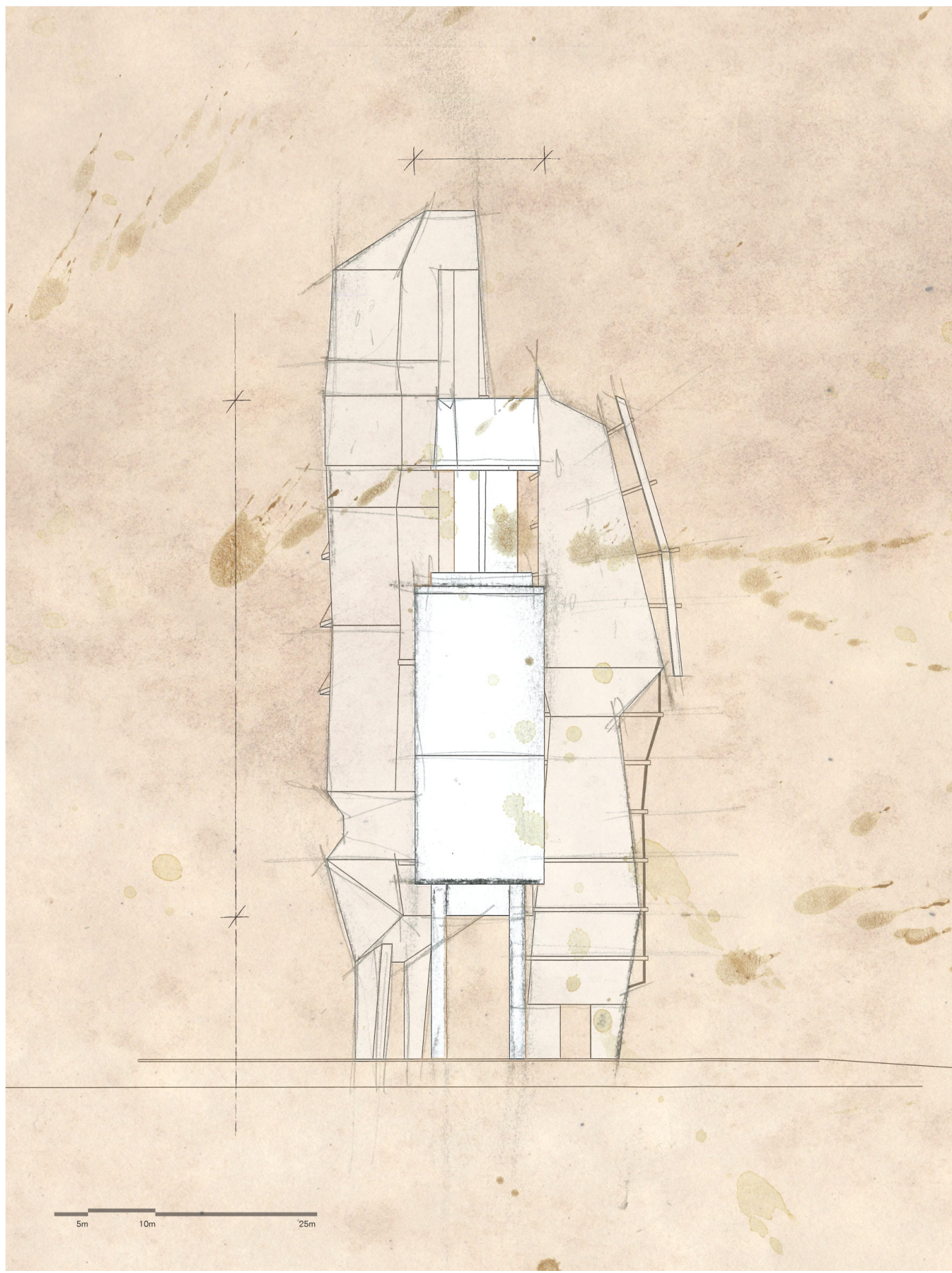

Figure 110.

Fragment 3.

Nourishment

and Reflection.

Elevation. 
FRAGMENT 3

NOURISHMENT AND REFLECTION 


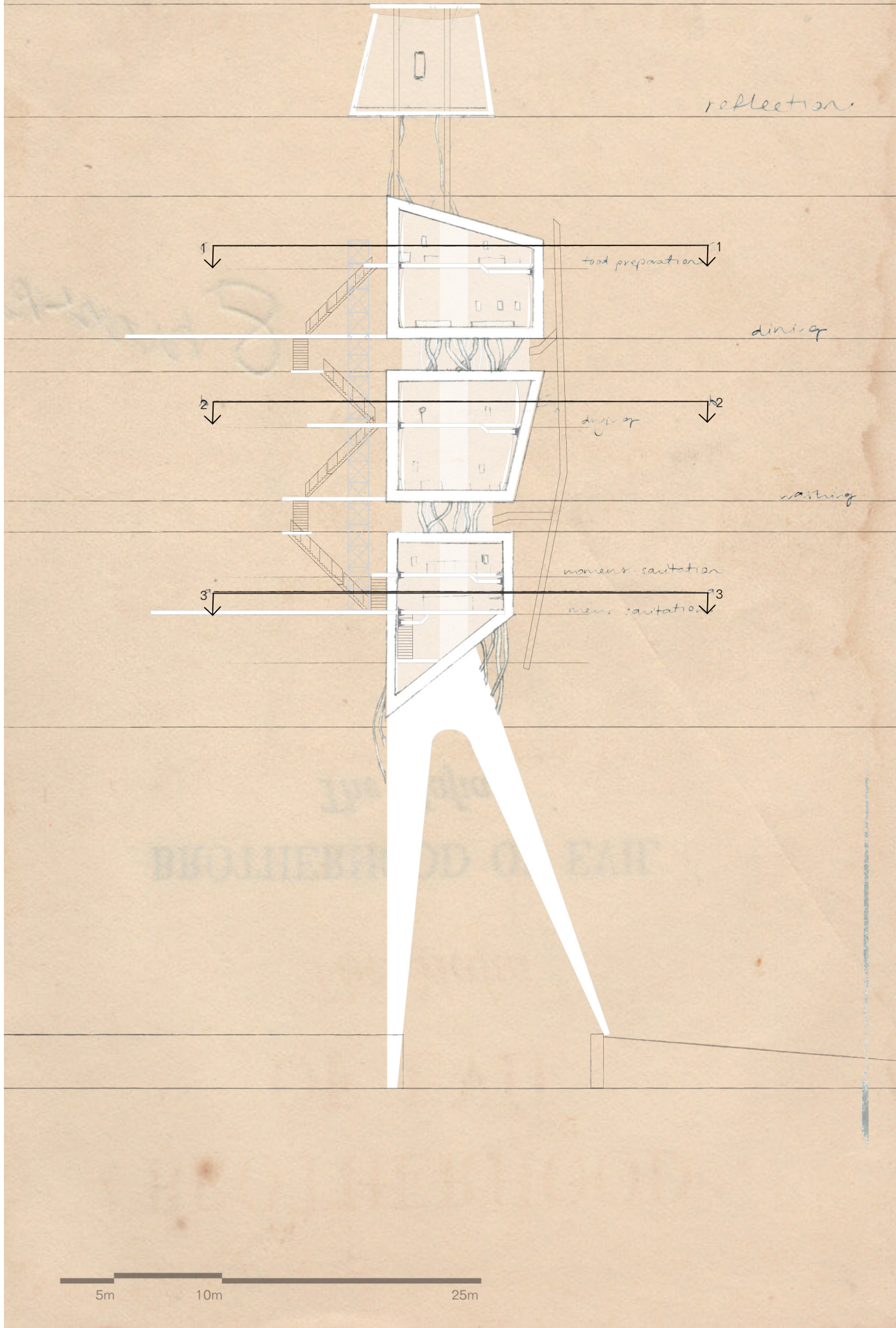

Figure 111

Fragment 3.

Nourishment

and Reflection.

Section AA. 


\section{SECTION}

7 he third fragment provides spaces for

1 nourishment, sanitation and reflection. The abdomen has three volumes to provide food preparation and consumption, sanitation of clothing, and personal sanitation and waste. The abdomen faces the palmery/the oasis, as this block is the main source of water and fertility for the people in the building, as the palmery is for the city. The highest volume is the space for reflection, remote and separated offering views across the entire city, and faces toward Mecca in Saudi Arabia - the direction one faces to preform Islamic prayer (Islam being the most common religion in Palmyra).

This fragment also has a central core structure that provides basic services of toilet and kitchenette on every floor. On the inner face (left) the body meets the outdoor community levels in three places, this is where the stair and lift is also located.

The fragment is successful in answering the aims and objectives of the research investigation as the design decisions described above tell a narrative through the architecture by looking to important cultural sites throughout the city - specifically the palmery, the oasis and also Mecca, embodying the cultural future. 


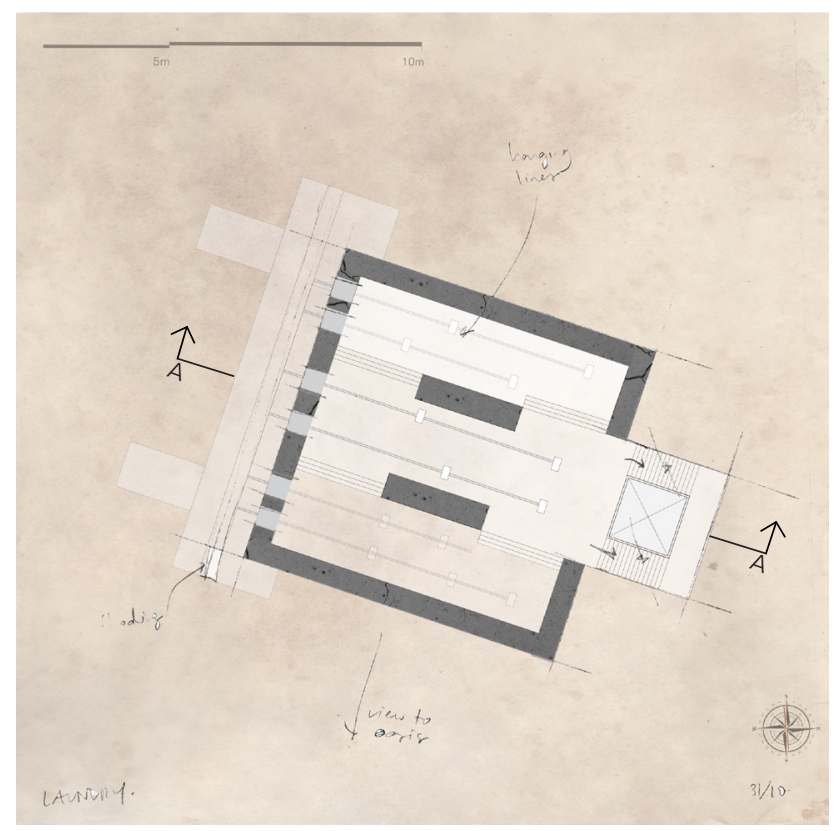

Figure 112.

Fragment

3. Laundry.

Plan 1.

Figure 113.

Fragment

3. Food

Preparation.

Plan 2. 
The interior floor plans are very open,

1 with services that are held within a core (shear walls) that permeate the entire building. There are communal spaces in the centre of the fragment and around the edge are private spaces on personal sanitation floors of varying sizes to reference the plan of the caravanserai analysed in the site analysis chapter.

The plan shows a contrast between thicker permanent exterior walls with thin internal moveable walls to reference the plan of a caravanserai, and the contrasting materials used in the Temple of Bel. This design decision relates to the aims and objectives by referencing the cultural past, and also a blending of the architecture. 
3

7

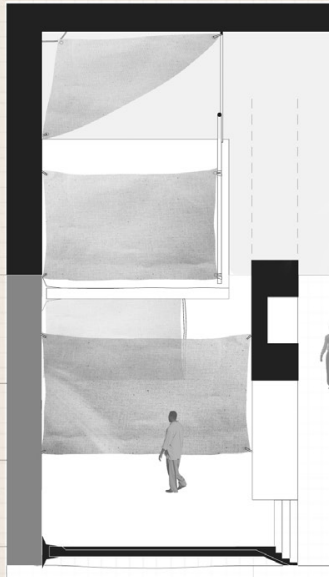

Fragment

2. Flat

axonometric

showing

flexible interior

elements. 
7 he thin internal walls that were described in the plan of each fragment previously are flexible elements made from canvas fabric and posts. These elements define interior spaces to allow for anywhere from an 8 person family unit to a 2 person family unit to coexist on one floor without harsh barriers, but divisions of space. The separation through canvas elements brings in the notion of the desert tent, as identified in the site analysis chapter. The interior plans are to intended to be read as a blending of the caravanserai and the desert tent.

The advantage of the flexibility is that the building can hold as many people as is needed or as few. Each floor becomes a community, and a community needs spaces to be together.

This blending provides a togetherness within the community and poses the ability to connect strangers who have shared a similar trauma. It will aid the transition of newcomers, for example when one family arrives for the first time and moves onto a floor with a family that has been there for 2 months, they can help and support each other. 
Figure 116.

Journey to

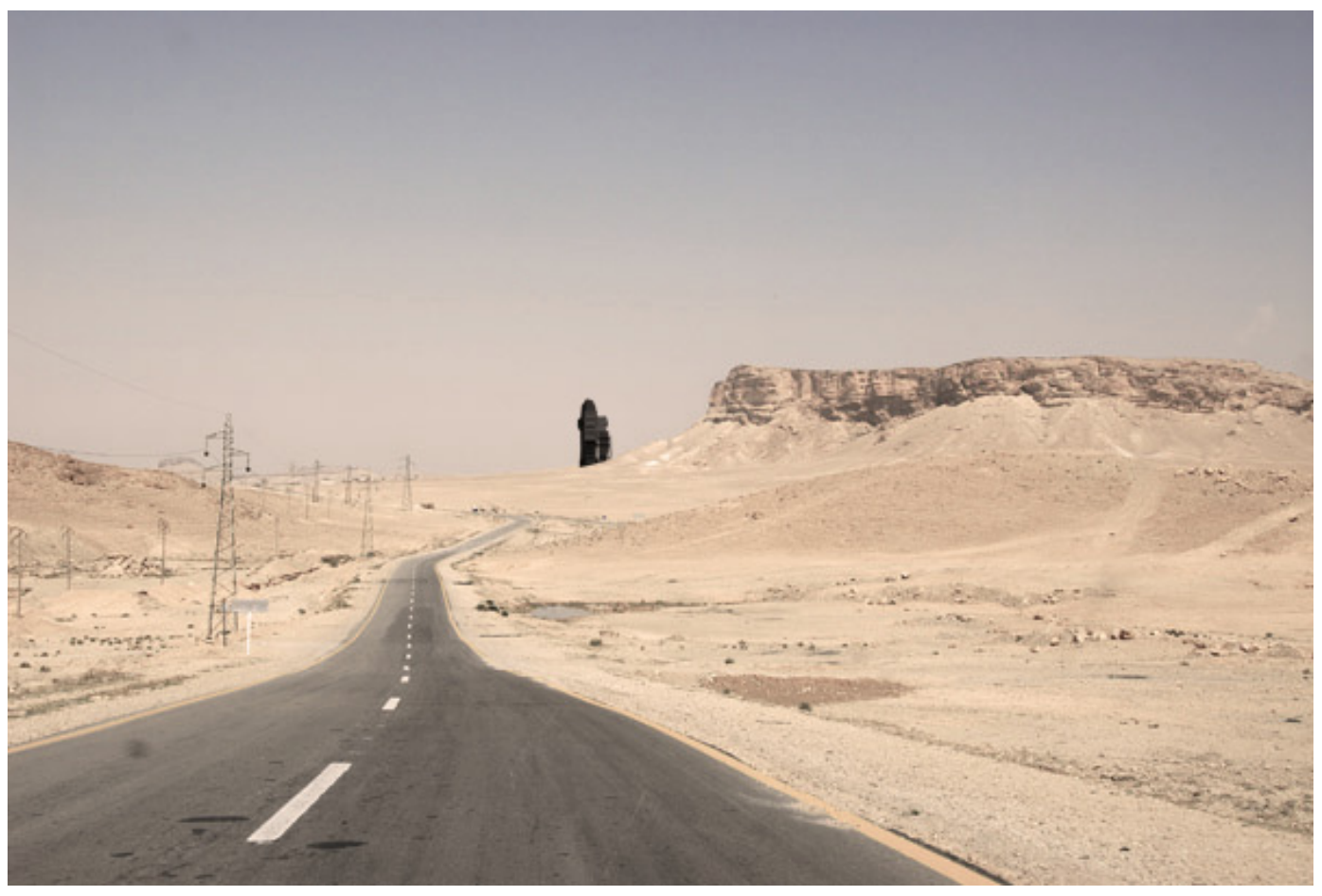


Arrival in

Palmyra.

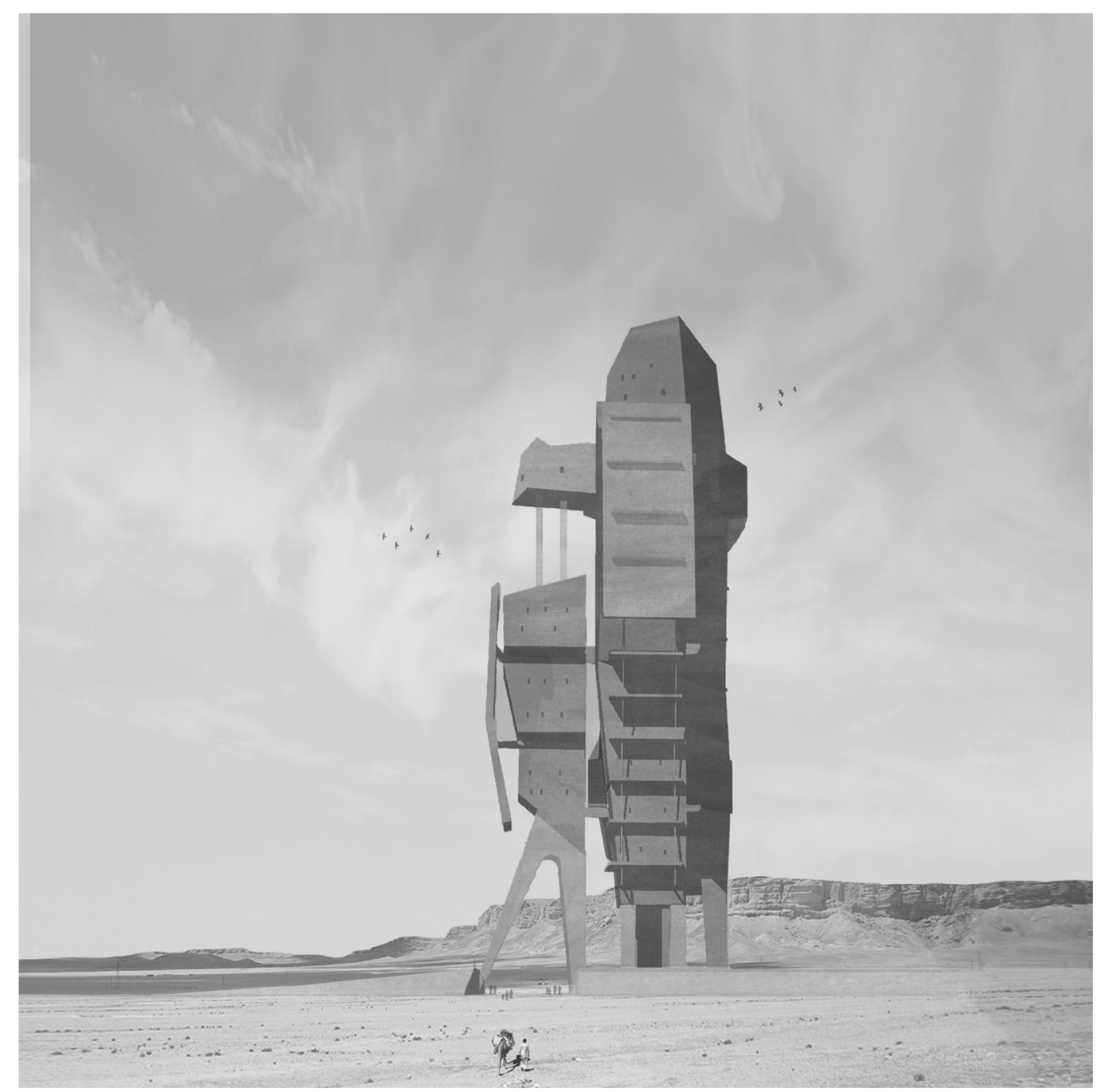




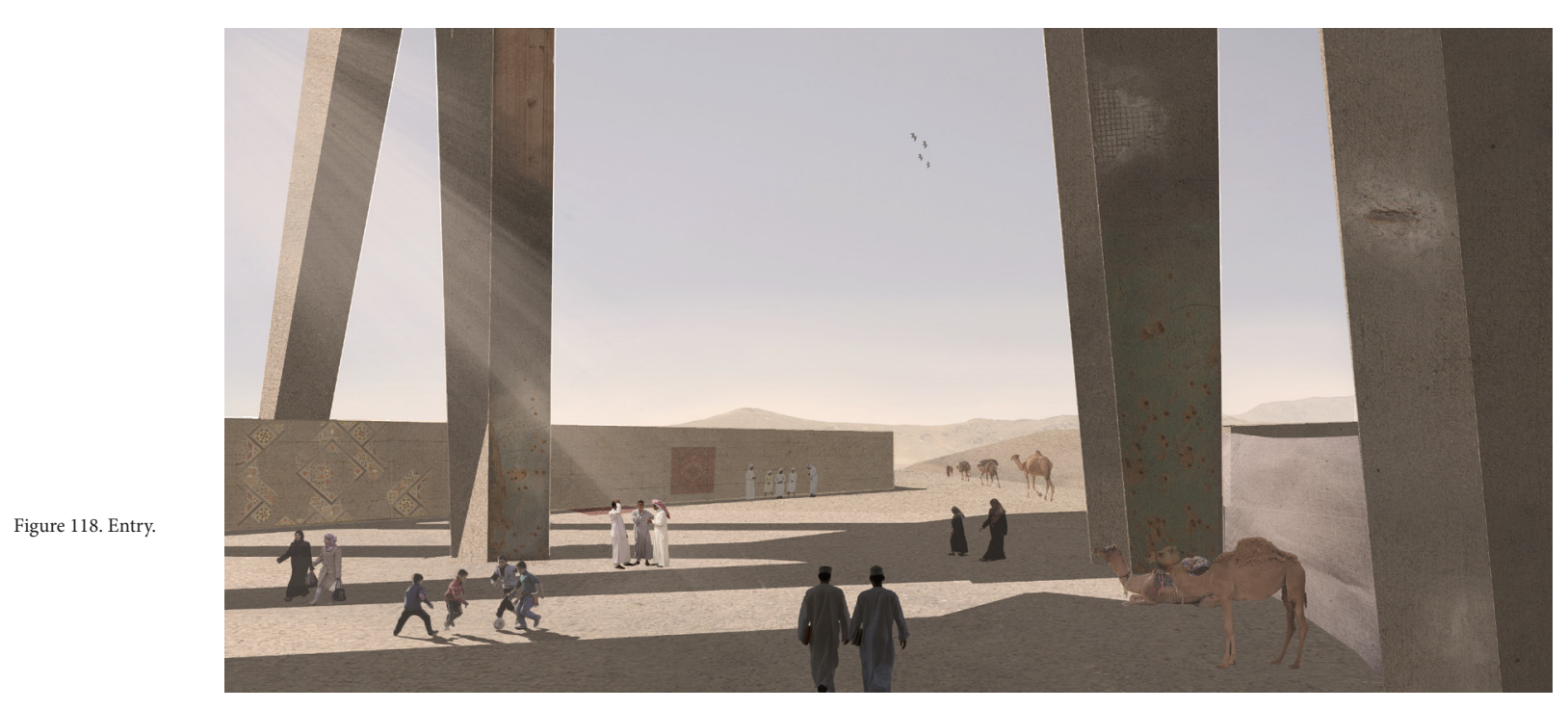




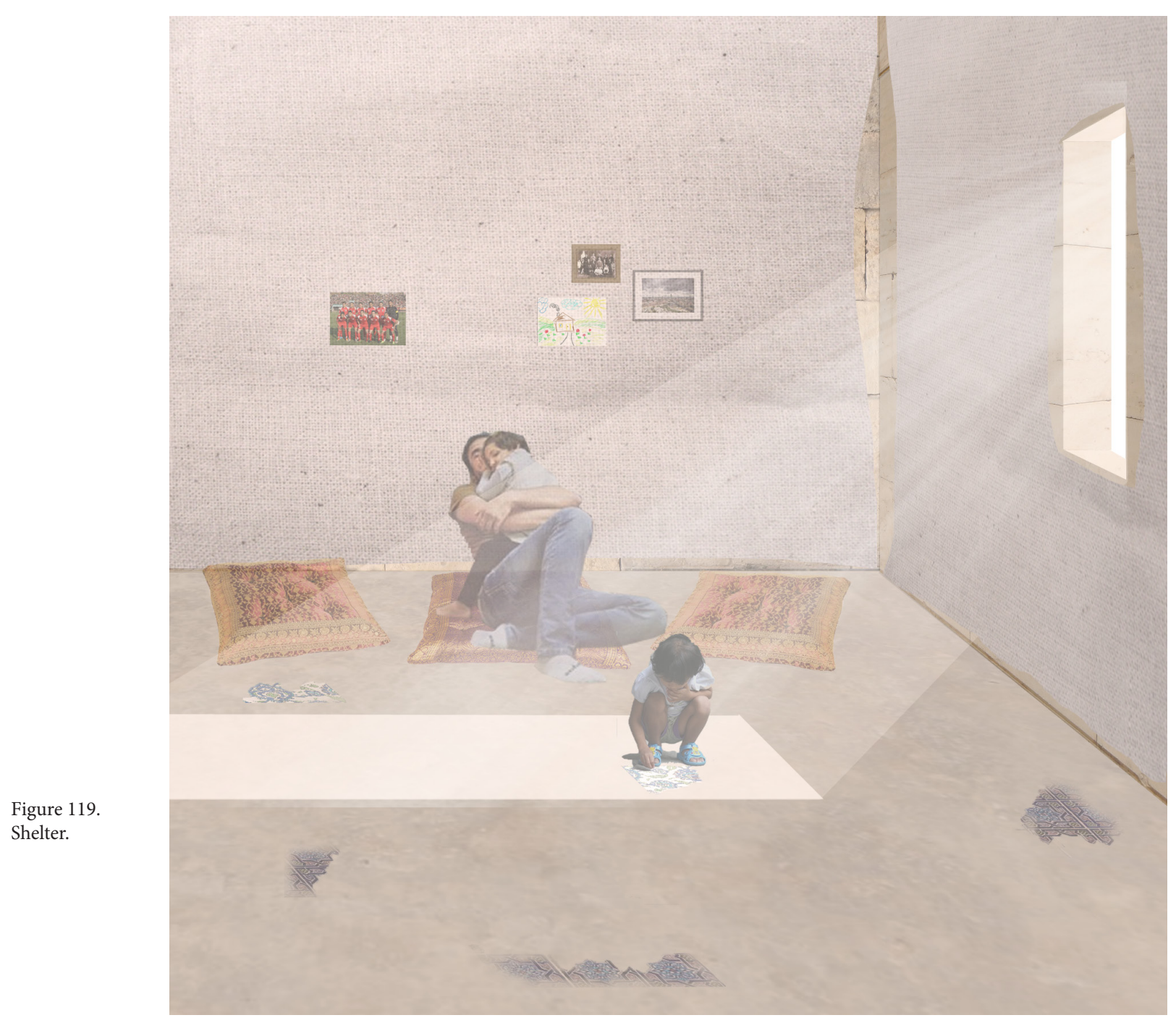




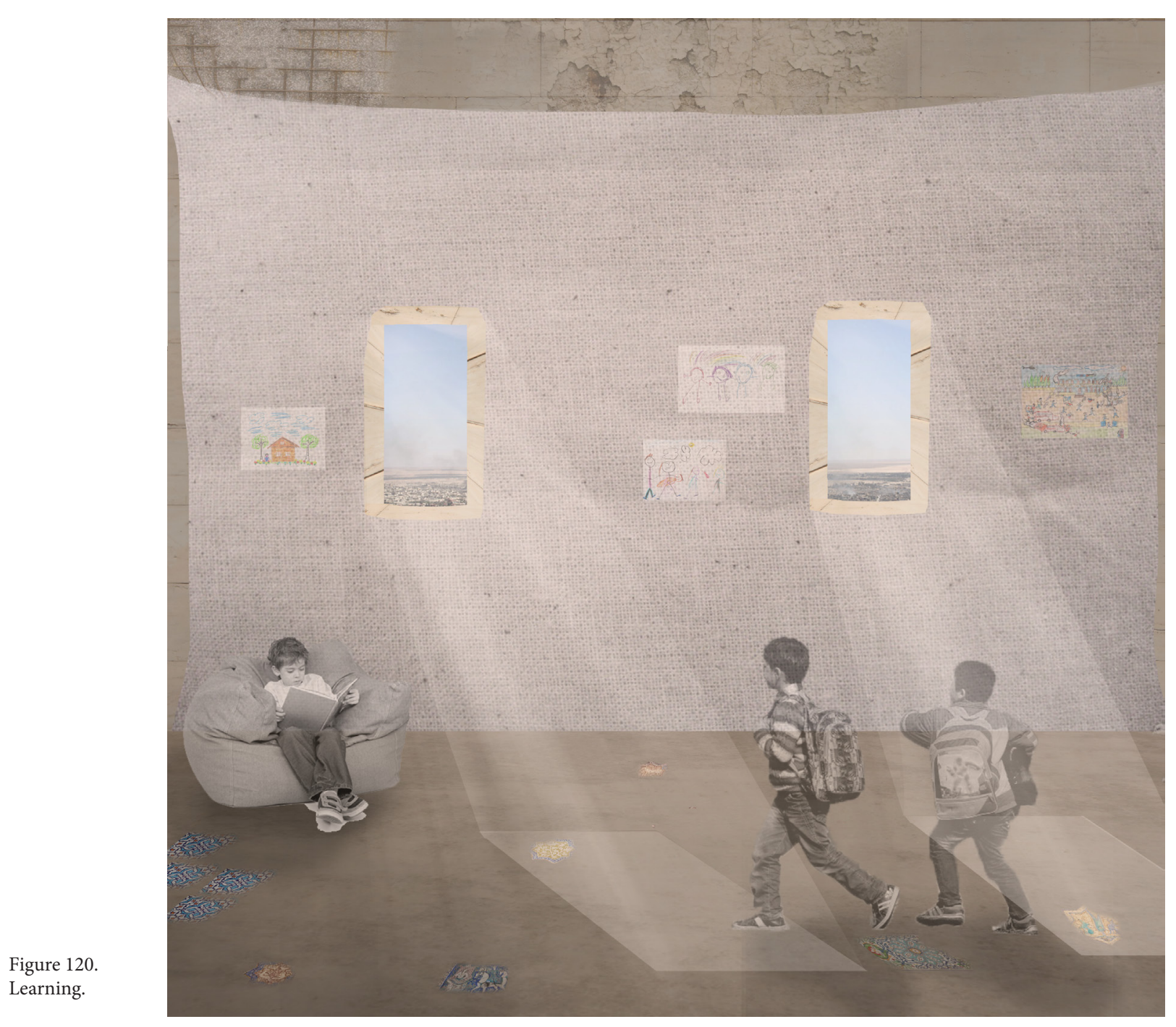


Figure 121.

View out over

modern city.

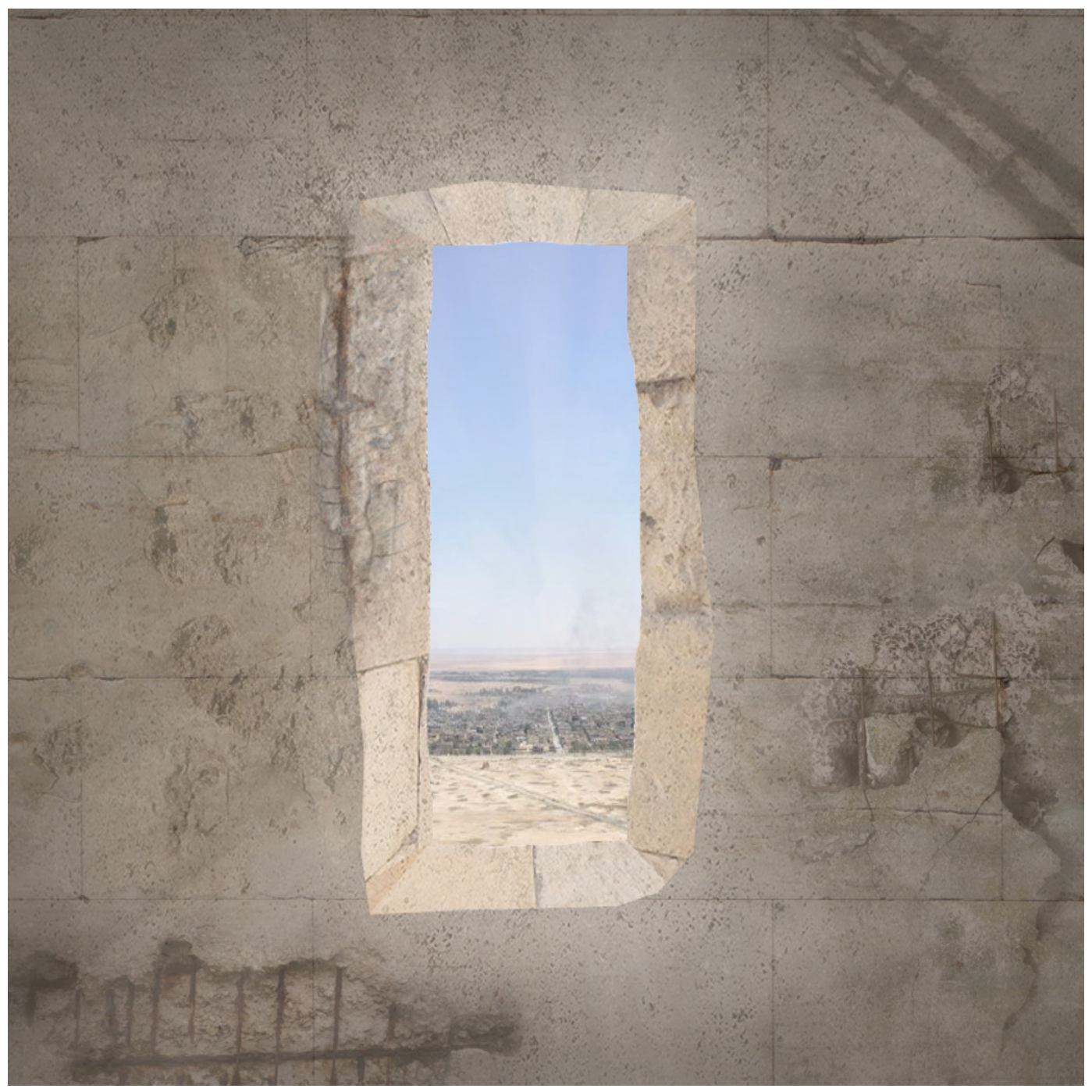


Figure 122.

Outdoor

community

space. Pockets for reflection.

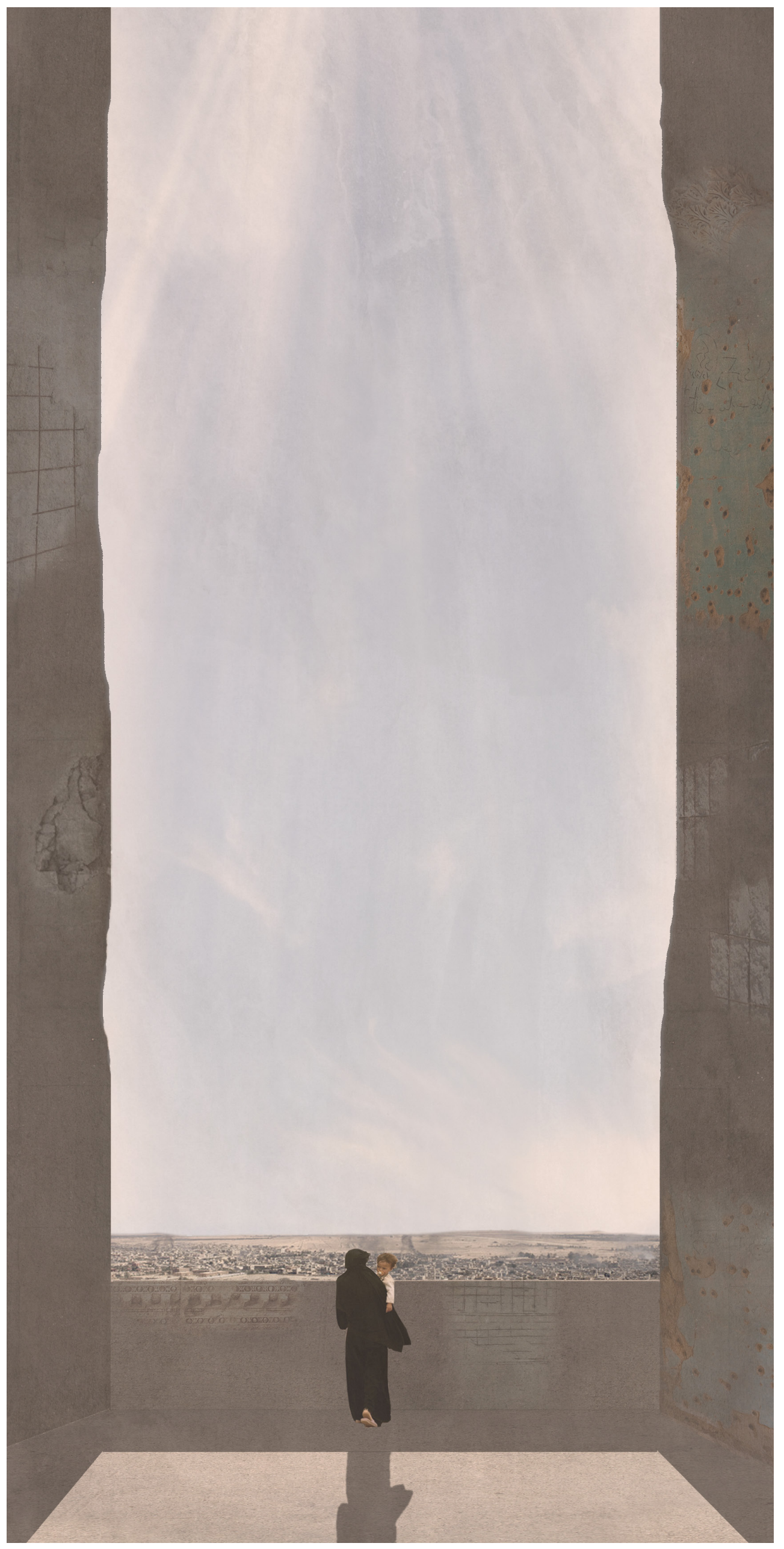




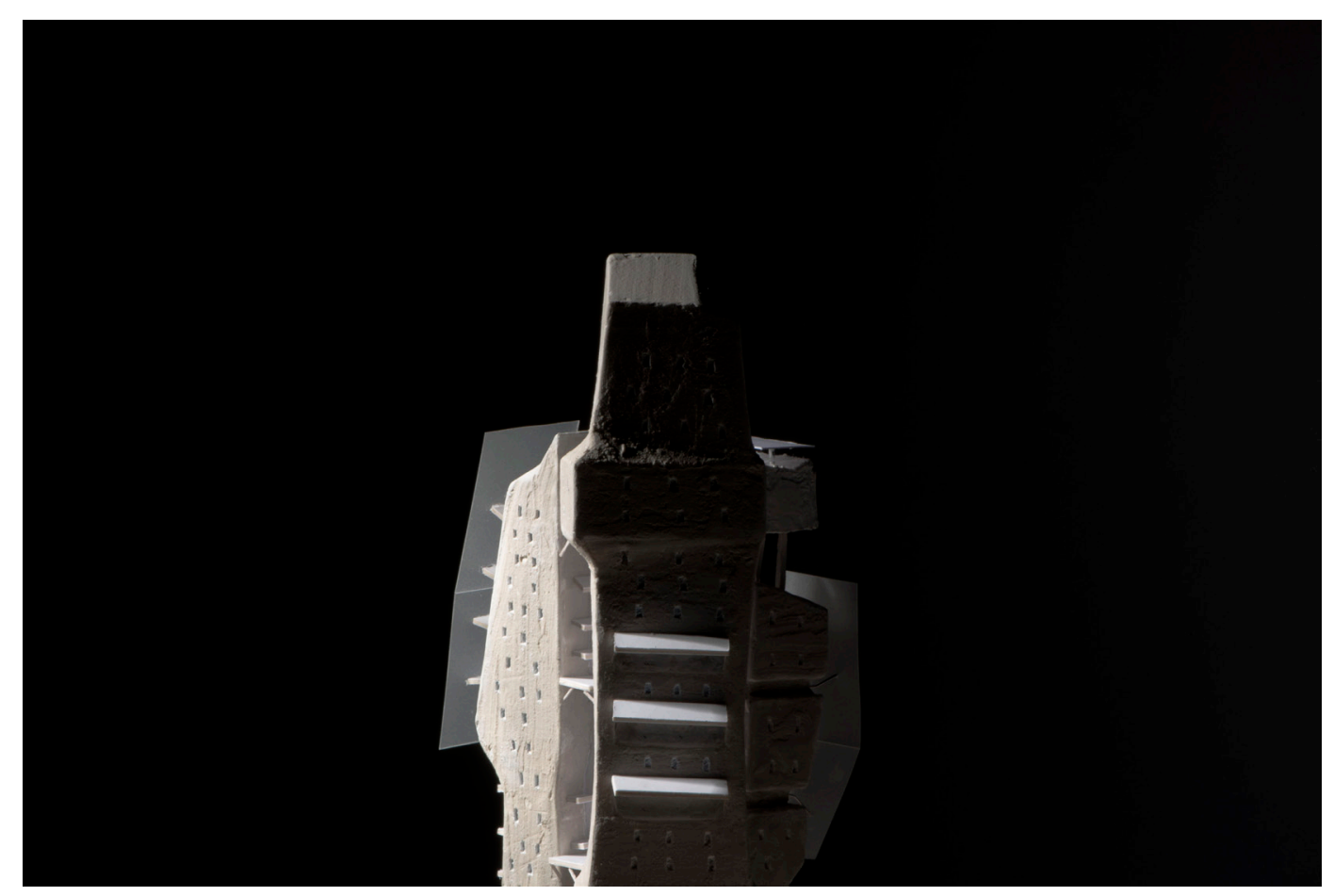

Figure 123

The Bride 
Figure 124

The Bride

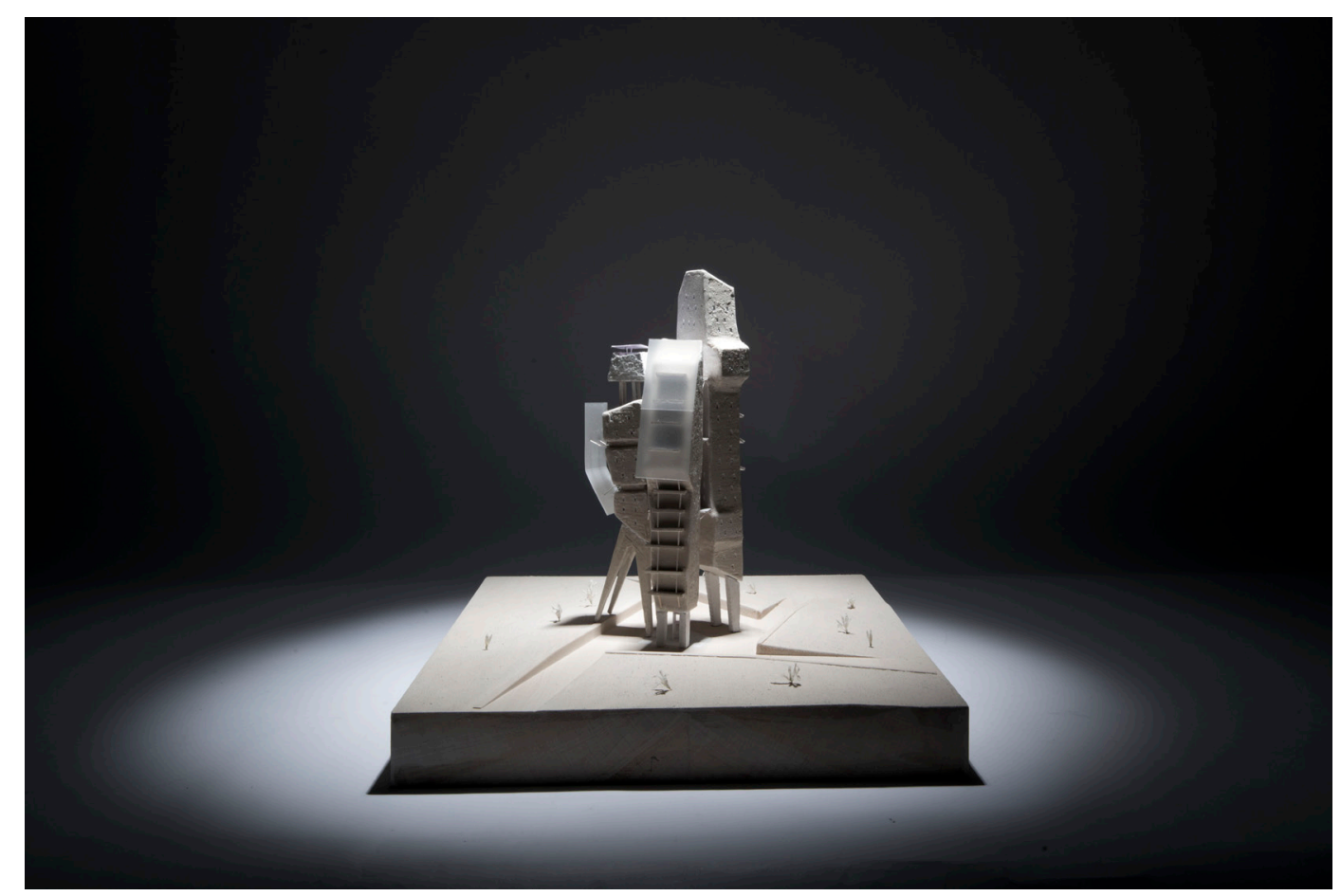




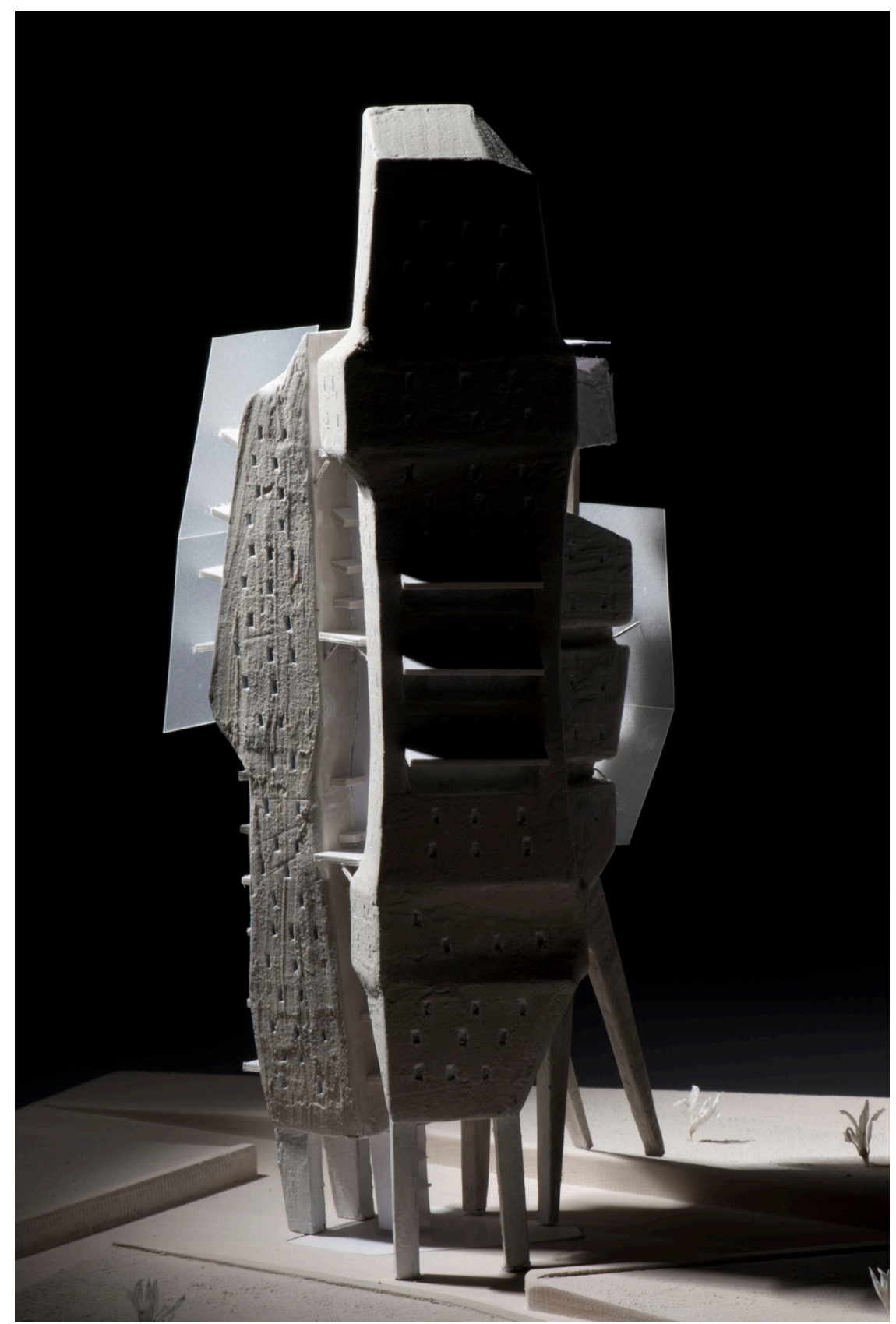

Figure 125.

The Bride

standing tall. Front of

fragment 2 . 
Figure 126.

Side of

fragment

1 showing

central

outdoor

gathering

spaces

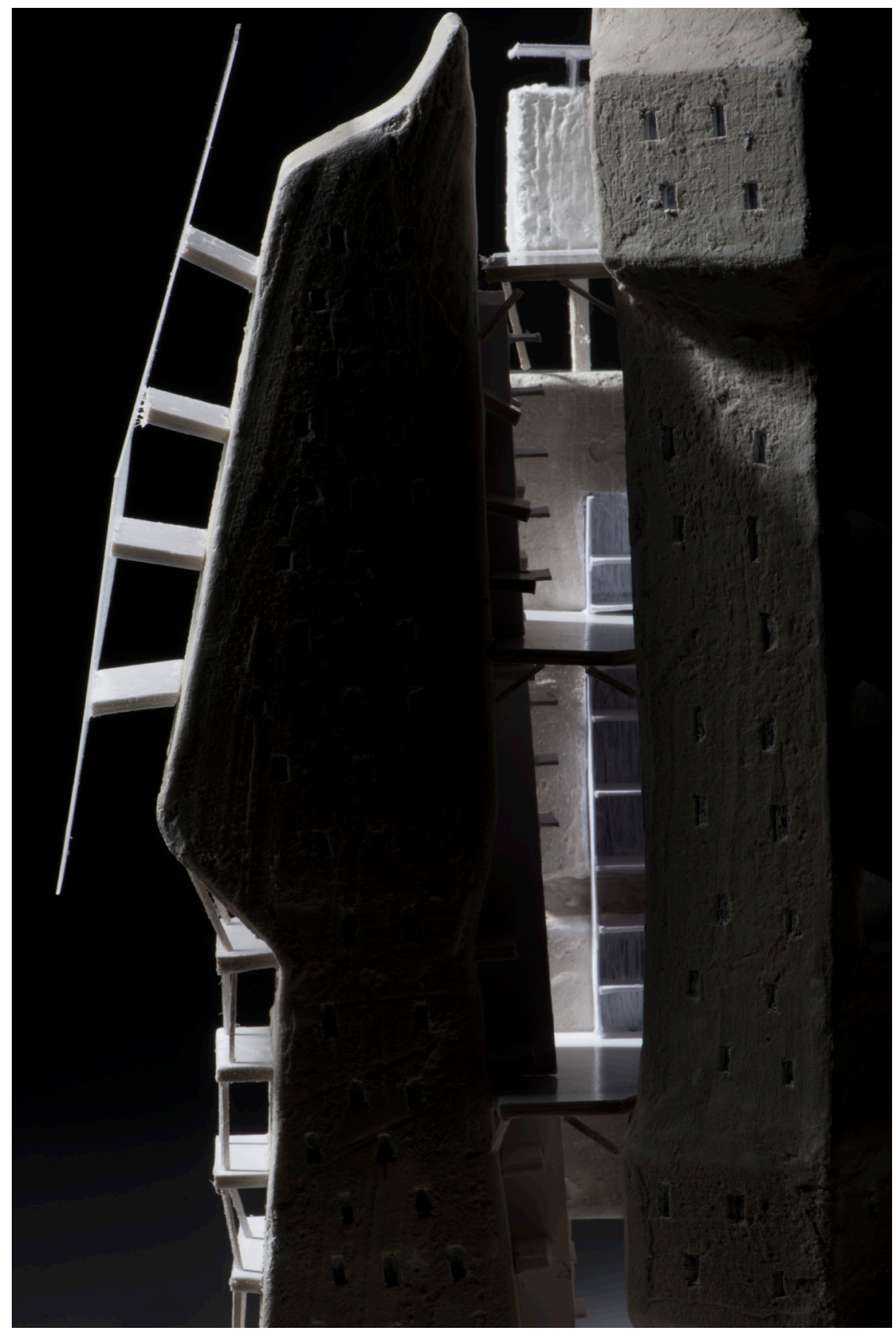




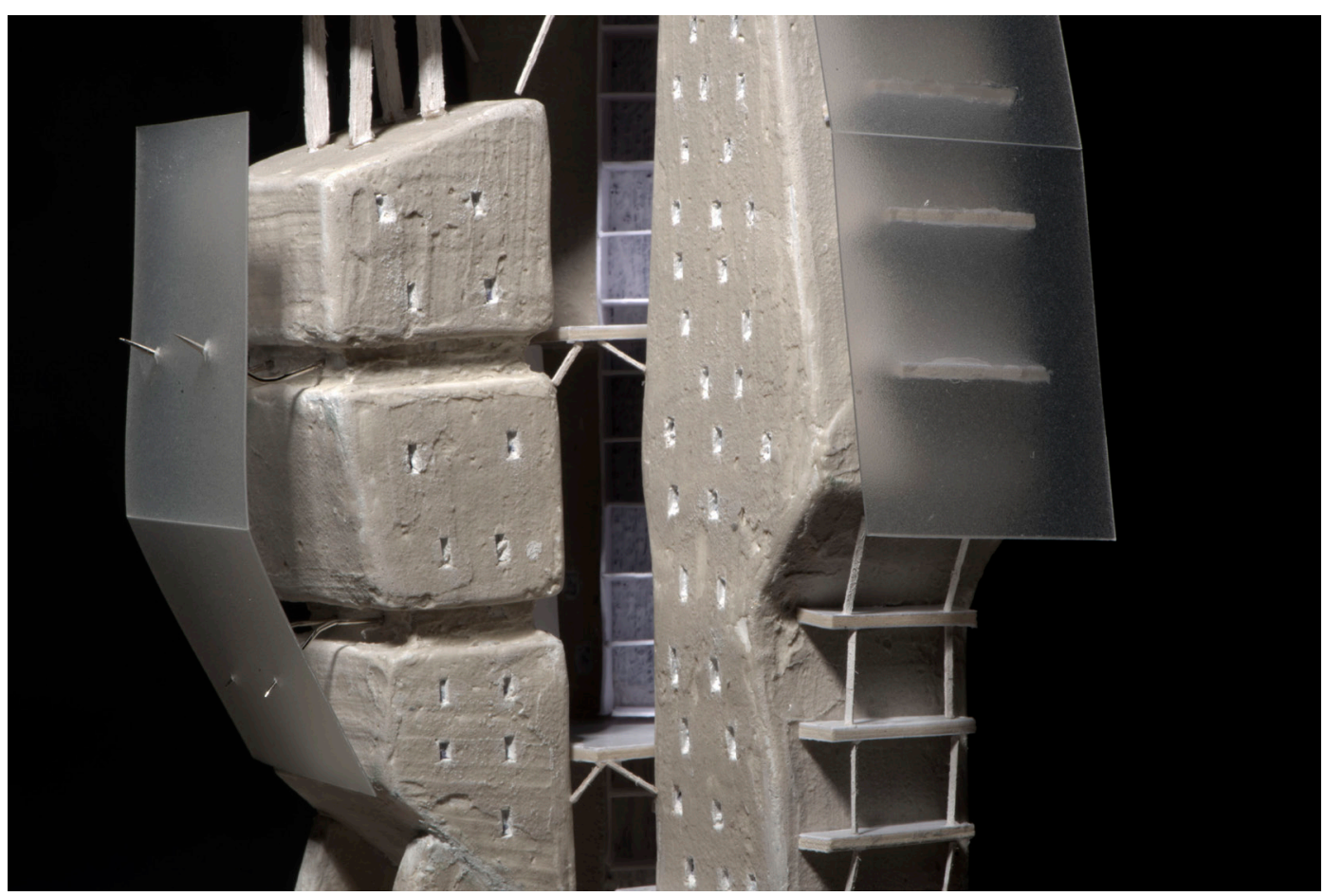

Figure 127

Fragment 1

and 3 showing

central

gathering

levels. 
Figure 128

Entry through

the legs of

fragment 3

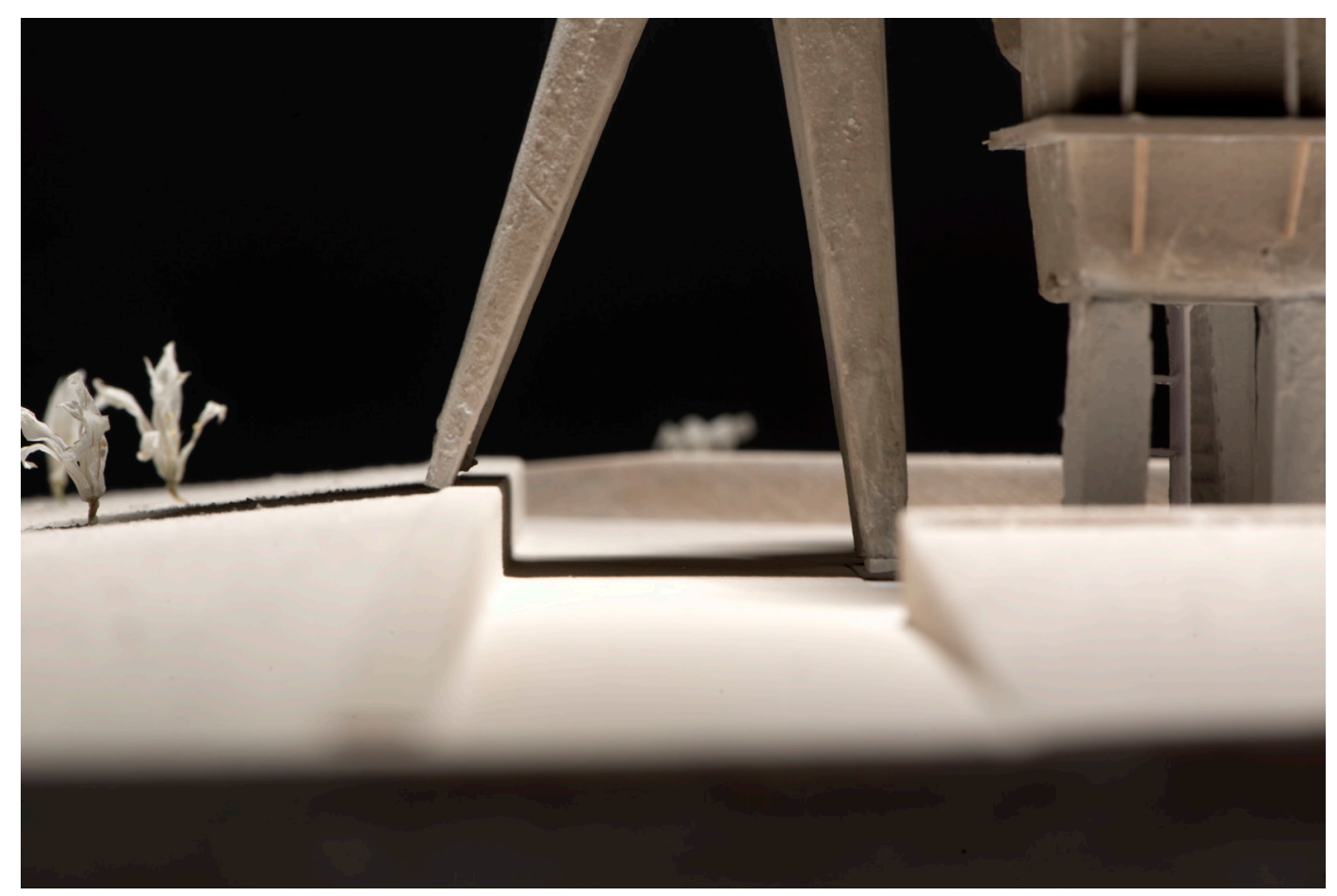


verall, this design enables the returning
refugees to reflect upon the devastation as one segment of an ongoing eternal time line that is linked back to their ancient civilization. This is so the recent war is not perceived as an ending of their community, but instead as an important reminder of a greater narrative that everyone shares, a narrative that can help define their strength and resilience.

The design presented in this chapter has successfully achieved the aims, objectives and the answers the research question that this thesis poses.

The design achieves the aims as it embodies the cultural past, looks to the cultural future and responds to both the past, the torn, and the future urban landscape; allows the inhabitants to reflect on loss and aids in restoring the identity of Palmyra and ultimately creates a place of sanctuary that the Palmyrenes can return to after the war; provides a place that enables the people to generate a new sense of cultural ownership, identity and control in response to the destruction of their historic homeland.

The design achieves the research objectives by proposing a speculative scheme; the second objective to have an anthropomorphic presence on the site; the third as tell a narrative about the broken city of Palmyra; the fourth as they respond to contextual elements of place; and the fifth as they suggest inhabitation within their abstract, sculptural volumes.

The various design experiments highlighted the importance of connection with site for this scheme. A lot of initial experiments were siteless to begin with, which led to failure when placed within the site, as the contextual connection was lacking. It was not until revisiting site analysis and the works by theorists that this connection was able to be made in later preliminary design stages. 


\section{7 \\ CONCLUSION}


$\mathrm{T}_{\mathrm{i}}^{\mathrm{s}}$ he problem that this design led research investigation is responding to is the largest global migration in history which has been caused by the Syrian War. More than 11 million refugees have been forced to leave their home country due to political conflict. The city of Palmyra is one of the many cities that has been destroyed by war, and many Palmyrenes who have fled will be returning to a destroyed community.

The problem becomes more than simply providing housing - it is also about how to provide a renewed sense of community as well as cultural and place identity for the returning refugees.

This topic is becoming increasingly more important because this is a problem that will be happening soon, but has not happened yet, and architects need to prepare a solution before the crisis occurs.

The reviews throughout the year taught me that a clear decision as to whether a design is to be built or remain purely speculative needs to be made. As this will then affect the type of detail that the design is resolved to, as well as the steps preceding the design stage that need to be taken (cost, materials, labour) and also defining the scope of the project.

A second important thing that was discovered through researching theorists and case studies is that architecture can draw variably from outside its own discipline, and that symbolism, narrative, anthropomorphism and abstract scuplture can introduce valuable design opportunities for looking at important issues in new ways.
Through this process I learnt that architecture can be both built and unbuilt, and could be more expressive if unbuilt. The final design proposition for this investigation has been designed so that it could be built but has limitations of realistic parameters such as cost, materials, and time which have not been considered. It is ultimately to be experienced through drawing. This way of working was inspired by Lebbeus Woods, who believed that as well as the architecture we inhabit every day, architecture is also the ideas and concepts and visions that are drawn. They can be inhabited but lack money, materials and time to be built to effectively solve the problem at hand.

If this project were to be further developed and extended beyond its original scope a version of this design could be built where realistic parameters of time, money and materials could be considered as these were limitations for the scope. The result would be a sanctuary for returning refugees that enables a new sense of cultural ownership and identity. Narrative elements would be included to tell the story of Palmyra; materiality would be deeply connected to its context; it would stand tall as a heroine keeping guard of the people, and ultimately provide a inhabitable sanctuary for returning families.

I have known since the beginning it would be an impossible task to solve the refugee crisis in Syria. To build a building like this would only create its own problems as the creation of housing and infrastructure would become an endless cycle. I am working in the discipline of architecture, and I have designed this project so it can be built, but the goal is for it to be a speculative design and for it to be experienced through drawing. I have taken the challenge to envisage my own chapter in the extensive history of Palmyra. 

fin

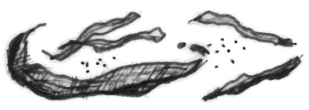




\section{WORKS CITED}

Abraham, Raimund. [Un]Built / Raimund Abraham with an Introductory Essay by Norbert Miller with Contributions by John Hejduk...[Et Al.] Edited by Brigitte Groihofer. Eds. Miller, Norbert and Brigitte Groihofer. Wien New York: Wien New York : Springer, 1996. Print.

Al-Sabouni, Marwa. The Battle for Home : The Vision of a Young Architect in Syria / Marwa AlSabouni Foreword by Roger Scruton. Ed. Scruton, Roger: New York, New York: Thames \& Hudson, 2016. Print.

Anderson, Lamar. More Than Just Sci-Fi: Lebbeus Woods' Retrospective To Open At SFMOMA. Architizer. Web. 2017. <https://architizer.com/blog/inspiration/industry/lebbeus-woodssfmoma/>

Bachelard, Gaston. The Poetics of Space / Gaston Bachelard Translated from the French by Maria Jolas with a New Foreword by John R. Stilgoe. Ed. Jolas, M. Boston: Boston : Beacon Press, 1994. Print.

Ban, Shigeru. Shigeru Ban : Paper in Architecture / Essays by Riichi Miyake Edited by Ian Luna \& Lauren A. Gould. Eds. Miyake, Riichi, Ian Luna and Lauren A. Gould. New York: New York : Rizzoli International Publications, 2009. Print.

Ban, Shigeru, and Museum Aspen Art. Shigeru Ban : Humanitarian Architecture / Contributors, Shigeru Ban, Claude Bruderlein, Michael Kimmelman, Koh Kitayama, Brad Pitt, Naomi Pollock, Eyal Weizman, Heidi Zuckerman Jacobson. Humanitarian Architecture: New York, N.Y. : D.A.P./Distributed Art Publishers Aspen, CO : Aspen Art Museum, 2014. Print.

Barenstein, Jennifer E. Duyne. "Post-Disaster Reconstruction and Change Communities' Perspectives." Post-Disaster Reconstruction and Change: Communities' Perspectives. Ed. Leemann, Esther. Hoboken: Hoboken : CRC Press, 2012. Print.

Bell, Jonathan. "Dark Arts: Peter Zumthor and Louise Bourgeois' Brooding Steilneset Memorial." Wallpaper* 4 July 2011. Web. 4 April 2017. <https://www.wallpaper.com/architecture/ steilneset-by-peter-zumthor-and-louise-bourgeois>

Bloom, Harold. Marcel Proust's Remembrance of Things Past / Edited and with an Introduction by Harold Bloom. New York: New York : Chelsea House, 1987. Print.

Burns, Iain. "What Remains of the Once-Magnificent Ancient City of Palmyra after Six Years of War in Syria and a Campaign of Destruction by Isis." Daily Mail 2017. Web 2017.

Burns, Ross. "The Monuments of Syria a Guide / Ross Burns." Ed. ebrary, Inc. London: London : I.B.Tauris, 2009. 206. Print.

Cáceres, Luis, et al. "Relative Humidity Patterns and Fog Water Precipitation in the Atacama Desert and Biological Implications." Journal of Geophysical Research: Biogeosciences 112.G4 (2007): n/a-n/a. Print.

Charlesworth, Esther Ruth. "Humanitarian Architecture : 15 Stories of Architects Working after Disaster / Esther Charlesworth." Ed. Ebooks, Corporation: Abingdon, Oxon New York, NY : Routledge, 2014. Print.

Cook, Peter. Drawing : The Motive Force of Architecture / Peter Cook. Chichester, England London: Chichester, England London : Wiley, 2008. Print.

---. Peter Cook, 1961-1989 / Editor Toshio Nakamura. Ed. Nakamura, Toshio. Tokyo: Tokyo : AtU Publishing Co., 1989. Print.

Daghastani, Soumer. "Inside Tadmur: The Worst Prison in the World?" BBC.com 2015. Web. 2017. $<$ http://www.bbc.com/news/magazine-33197612> 
Darden, Douglas. Condemned Building : An Architect's Pre-Text / Douglas Darden. New York, N.Y.: New York, N.Y. : Princeton Architectural Press, 1993. Print.

Dearden, Lizzie. "Syrian Civil War: More Than Five Million Refugees Flee Conflict as Global Support for Resettlement Wanes." Independent.co.uk 30 March 2017. Web. 2017. <http:// www.independent.co.uk/news/world/middle-east/syria-civil-war-five-million-refugeesconflict-resettlement-un-geneva-donald-trump-europe-migrant-a7658606.html>

Deconstruction Ii. London: London : Academy Editions, 1989. Print.

Dictionary, Oxford. Oxford Dictionary Definition of Refugee in English. Web 2017.

Domingo, Niluka, and Hao Luo. "Canterbury Earthquake Construction and Demolition Waste Management: Issues and Improvement Suggestions." International Journal of Disaster Risk Reduction 22 (2017): 130-38. Print.

Dunne, Anthony; Raby, Fiona. Speculative Everything. CAMBRIDGE, MASSACHUSETTS LONDON, ENGLAND: CAMBRIDGE, MASSACHUSETTS. LONDON, ENGLAND: The MIT Press, 2013. Print.

Entwistle, Sarah. Please Send This Book to My Mother : Sarah Entwistle / [Edited by Ariella Yedgar]. Eds. Yedgar, Ariella and Corbusier Fondation Le. Berlin: Berlin : Sternberg Press, 2015. Print.

Flinder, Sophie. "Camps Like the Jungle Are "an Important Resource for All Urban Professionals to Study'”' Ed. Fairs, Marcus. www.dezeen.com: Dezeen, 2016. Print.

Gates, 2003, p.390-91

Gardiner, Juliet. "Journey through the Afterlife: Ancient Egyptian Book of the Dead." London: History Today Ltd., 2011. 56. Vol. 61. Print.

Grady, Denise. "Walter Pichler, an Artist Who Bucked the Status Quo, Dies at 75." New York Times July 28 2012. Web 2017.

Hays, K. Michael. Sanctuaries, the Last Works of John Hejduk : Selections from the John Hedjuk Archive at the Canadian Centre for Architecture, Montreal and the Menil Collection, Houston / K. Michael Hays Preface by Toshiko Mori. Sanctuaries. Ed. Hejduk, John. New York: New York: Whitney Museum of American Art, 2002. Print.

Hejduk, John, et al. Education of an Architect / John Hejduk, Dean, Richard Henderson, Associate Dean Editors, Elizabeth Diller, Diane Lewis, Kim Shkapich the Irwin S. Chanin School of Architecture of the Cooper Union. New York: New York : Rizzoli, 1988. Print.

Herz, Manuel. From Camp to City : Refugee Camps of the Western Sahara / Edited by Manuel Herz. Zürich, Switzerland : Lars Muller Publishers Basel : ETH Studio Basel, 2013. Print.

Hornstein, Shelley. Losing Site : Architecture, Memory and Place / Shelley Hornstein. Architecture, Memory and Place. Farnham, Surrey, England Burlington, VT: Farnham, Surrey, England Burlington, VT : Ashgate, 2011. Print.

Kain, Gavin; Hafteh, Georgina. Case Studies of Urban Regeneration: Christchurch and Palmyra. May 2015.Web. <https://issuu.com/woods_bagot/docs/150529_public_urban_ regeneration_ca>

Leach, Neil, and ProQuest. Architecture and Revolution : Contemporary Perspectives on Central and Eastern Europe / Edited by Neil Leach. London New York: London New York : Routledge, 1999. Print. 
Leoni, Claudio. “Peter Zumthor’s ‘Topography of Terror.” 18.2 (2014): 110-22. Print.

Miss, Mary. Mary Miss / Mary Miss with Essays by Daniel Abramson, Eleanor Heartney, and Joseph Giovannini. Eds. Abramson, Daniel M., Eleanor Heartney and Joseph Giovannini. New York : Abingdon: New York : Princeton Architectural Abingdon : Marston, 2002. Print.

Nazarevskaia, Kristina “Gutai Member Takesada Matsutani Makes Paintings with Glue.” GalleryIntell 22 May 2016. Web. 04 April 2017. <http://www.galleryintell.com/takesadamatsutani-at-hauser-wirth/>

Ostwald, Michael J. Residue : Architecture as a Condition of Loss / Michael J. Ostwald, Chris Tucker, Michael Chapman. Eds. Tucker, Chris and Michael Chapman. Melbourne, Vic.: Melbourne, Vic. : RMIT University Press, 2007. Print.

Pichler, Walter. Walter Pichler : Drawings, Sculpture, Buildings / with an Introduction by Friedrich Achleitner. New York: New York : Princeton Architectural Press, 1993. Print.

---. Walter Pichler : Drawings, Sculptures, Architecture / Text by Diane Lewis. Drawings, Sculptures, Architecture. Ed. Lewis, Diane. Salzburg: Salzburg : Jung und Jung, 2001. Print.

"Residents Flee Palmyra as Syrian Government Bombs Isil." Al Jazeera America2015. Web. <http:// www.aljazeera.com/news/2015/09/residents-flee-palmyra-syrian-government-bombsisil-150923200307921.html>

Review By Edwin, Heathcote. “The Book of Laughter and Forgetting.” FT.com (2007): 1. Print.

Sahner, Christian. “Temple of the 'Bride of the Desert"' Mybyzantine.wordpress.com 2011. Web. 2017. < https://mybyzantine.wordpress.com/2011/10/16/temple-of-the-bride-of-thedesert/>

Schneider, Bernhard. Daniel Libeskind : Jewish Museum Berlin : Between the Lines / Preface by Daniel Libeskind Text by Bernhard Schneider Photographs by Stefan Muller [Translated from the German by John William Gabriel]. Jewish Museum Berlin. Ed. Libeskind, Daniel. Munich New York: Munich New York : Prestel, 1999. Print.

Schutyser, Tom. Caravanserai : Traces, Places, Dialogue in the Middle East / [Photographs and Texts] Tom Schutyser [for Their Texts, Reza Aslan [and Others]] = CaravanséRails : Traces, Places, Dialogue Au Moyen-Orient / [Photographie Et Textes] Tom Schutyser [Pour Leurs Textes, Reza Aslan [and Others]]. CaravanséRails : Traces, Places, Dialogue Au Moyen Orient. Ed. Aslan, Reza. Milan, Italy: Milan, Italy : 5 Continents Editions, 2012. Print.

Self, Will. The Book of Dave / Will Self. London: London : Viking, 2006. Print.

Slater, Julia. "Urban Systems of the Refugee Camp." Syracuse School of Architecture, December 2014. Print.

Terpak, Frances; Bonfitto, Peter Louis. “Temple of Bel”. The Legacy of Ancient Palmyra. The Getty Research Institute. Retrieved 10 February 2017.

Thwaites, Thomas. “The Toaster Project, or, a Heroic Attempt to Build a Simple Electric Appliance from Scratch / Thomas Thwaites." Heroic attempt to build a simple electric appliance from scratch. Ed. ProQuest. 1st ed.. ed. New York: New York : Princeton Architectural Press, 2011. Print.

Till, Karen E. “New Berlin: Memory, Politics, Place.” (2005): 296. Print.

Walsh, Tony. "A Day at the Races.” Arab News 2004. Web. 2017. <http://www.omanholiday.co.uk/ Day-at-the-Races-by-Tony-Walsh-for-Arab-News.pdf> 
Wieseltier, Leon. “The Rubble of Palmyra." (September 4 2015). Print.

Wood, Robert; Fournier, Pierre Simon; Major, Thomas; Muller, J. S; Muller, T. M. Jr; Borra, Giovanni Battista. The Ruins of Palmyra, Otherwise Tedmor, in the Desart. London: Robert Wood, 1753. Print.

Woods, Lebbeus. Anarchitecture: Architecture as a Political Act. Vol. Volume 22 of Architectural Monographs. The University of Michigan: Academy Editions, 1992. Print.

---. “Architecture and Resistance." Wordpress 2009. Web. June 2017 2017. <https://lebbeuswoods. wordpress.com/2009/05/09/architecture-and-resistance/>

---. Lebbeus Woods : Terra Nova 1988-1991 / [Editor Toshio Nakamura). Ed. Nakamura, Toshio. Tokyo: Tokyo : a+u Publishing, 1991. Print.

---. “Open Questions.” Wordpress 2009. Web. 2017. <https://lebbeuswoods.wordpress. com/2009/03/10/architecture/>

---. The Storm and the Fall / Lebbeus Woods. New York: New York : Princeton Architectural Press, 2004. Print.

---. “Storm Watch.” Wordpress 2009. Web. June 2017 2017. <https://lebbeuswoods.wordpress. com/2009/12/19/storm-watch/>

---. War and Architecture = Rat I Arhitektura / Lebbeus Woods. New York, NY: New York, NY : Princeton Architectural Press, 1993. Print.

---. "War and Architecture: The Sarajevo Window." Wordpress 2011. Web. June 2017. <https:// lebbeuswoods.wordpress.com/2011/12/02/war-and-architecture-the-sarajevo-window/>

Zumthor, Peter, and Architekturgalerie. Three Concepts : Thermal Bath Vals, Art Museum Bregenz, 


\section{LIST OF FIGURES}

All figures not attributed are author's own.

Figure 1. Moutafis, George. FSA fighter poses on his horse in grove of olive trees, March 16, 2012. al-Shatouria Village, Syria. Web. $<$ http://time.com/3794477/photographing-syrias-agonythe-images-that-moved-them-most/>

Figure 2. Meloni, Lorenzo. Home, April 2016. Homs, Syria. Web. $<$ http://pro.magnumphotos. com/C.aspx?VP3=SearchResult\&ALID=2K1HRGP77NNK>

Figure 3. Meloni, Lorenzo. Syrian Army soldier rests amongst the ruins, April 2016. Palmyra, Syria. Web. $<$ http://pro.magnumphotos.com/C.aspx?VP3=SearchResult\&ALID=2K1HRGP77N $\mathrm{NK}>$

Figure 4 Elevation Maplogs. Road to Palmyra, September 2015. Palmyra, Syria. Web. <http:// elevation.maplogs.com/poi/homs_governorate_syria.21210.html>

Figure 5. Carillet, J. Bullet-riddled rooms in Quneitra, Syria, n.d. Web. <http://www. gettyimages.co.nz/detail/photo/bullet-riddled-rooms-in-quneitra-syria-royalty-freeimage/168260235>

Figure 6. Pilgrim. A Bedouin's donkey, just outside of Palmyra, c.1990. Web. $<$ https://www. redbubble.com/people/pilgrim/works/710-syria-1990-donkey>

Figure 7. Vignes, Louis/J. Paul Getty Trust. Three-part Panorama of Palmyra Taken from the Camp of Diocletian, c.1863. Palmyra, Syria. Web. <http://teachmideast.org/articles/an-historicaland-contemporary-perspective-of-the-palmyra-ruins-in-syria-the-new-york-review-of-books/>

Figure 8. Meloni, Lorenzo. Syrian Army Soldiers climb on ruins of the Temple of Bel, April 2016. Palmyra, Syria. Web. $<$ http://pro.magnumphotos.com/C.aspx?VP3=SearchResult\&ALID=2 K1HRGP77NNK>

Figure 10. Fernandez Alcaide, Fernando. The palmery located south of the city, September 2017. Palmyra, Syria. Web. http://www.panoramio.com/photo/4917940

Figure 11. Burns, Iain. The ancient city, looking down the main colonnaded street to the Temple of Bel.

Daily Mail 2017. Web. <http://www.dailymail.co.uk/news/article-4891592/What-remainsmagnificent-city-Palmyra.html>

Figure 12. Burns, Iain. Modern city of Palmyra. Daily Mail 2017. Web. <http://www.dailymail. co.uk/news/article-4891592/What-remains-magnificent-city-Palmyra.html>

Figure 14. Malbeste, George. Middle section of Colonnade Street, ca. 1799. Paris, France. Web. $<$ http://www.getty.edu/research/exhibitions_events/exhibitions/palmyra/city_plan.html>

Figure 15. Niquet, Claude. Funerary Temple, ca. 1799. Paris, France. Web. < http://www.getty. edu/research/exhibitions_events/exhibitions/palmyra/city_plan.html>

Figure 18. Meloni, Lorenzo. Syrian Army soldiers take shade beneath massive pillars, April 2016. Palmyra, Syria. Web. http://pro.magnumphotos.com/C.aspx?VP3=SearchResult\&ALID=2K1 HRGP77NNK

Figure 19. Meloni, Lorenzo. Syrian Army soldiers take shade beneath massive pillars, April 2016. Palmyra, Syria. Web. $<$ http://pro.magnumphotos.com/C.aspx?VP3=SearchResult\&ALID=2K 1HRGP77NNK>

Figure 20. Meloni, Lorenzo. Syrian Army soldiers climb through rubble of Temple of Bel, April 2016. Web. $<$ http://pro.magnumphotos.com/C.aspx?VP3=SearchResult\&ALID=2K1HRGP77N $\mathrm{NK}>$ 
Figure 21. Meloni, Lorenzo. Entrance to Palmyra, April 2016. Palmyra, Syria. Web. < http://pro. magnumphotos.com/C.aspx?VP3=SearchResult\&ALID=2K1HRGP77NNK>

Figure 22. Meloni, Lorenzo. A destroyed residence, April, 2016. Palmyra, Syria. Web. < http:// pro.magnumphotos.com/C.aspx?VP3=SearchResult\&ALID=2K1HRGP77NNK>

Figure 23. Meloni, Lorenzo. Looking out from Palmyra to the castle, April 2016. Palmyra, Syria. Web. < http://pro.magnumphotos.com/C.aspx?VP3=SearchResult\&ALID=2K1HRGP77NNK>

Figure 24. Meloni, Lorenzo. Soldiers look down upon the city, April 2016. Palmyra, Syria. Web. < http://pro.magnumphotos.com/C.aspx?VP3=SearchResult\&ALID=2K1HRGP77NNK>

Figure 26. Google Maps image. Community camel racing track, 2017. Palmyra, Syria. Web. $34^{\circ} 33^{\prime} 39.2^{\prime \prime} \mathrm{N} 38^{\circ} 15^{\prime} 56.3^{\prime \prime} \mathrm{E}$.

Figure 27. Google Maps image. Tadmor Prison, 2017. Palmyra, Syria. Web. 34³3’31.2”N $38^{\circ} 17^{\prime} 07.1$ 'E

Figure 28. Google Maps image. Temple of Bel, 2017. Palmyra, Syria. Web. 34²32'50.5”N $38^{\circ} 16^{\prime} 26.2^{\prime \prime} \mathrm{E}$.

Figure 29. Google Maps image. Chosen site, 2017. Palmyra, Syria. Web. 34³4’37.5”N $38^{\circ} 17^{\prime} 19.8^{\prime \prime} \mathrm{E}$

Figure 30. Schutyser, Tom. Caravanserai, 2012. Middle East. Caravanserai : traces, places, dialogue in the Middle East. Schutyser, Tom. Milan, Italy. 5 Continents Editions, 2012. Book.

Figure 31.Wood, Robert. Temple of Bel floor plan, 1753. Palmyra, Syria. The Ruins of Palmyra, Otherwise Tedmor, in the Desart. Wood, Robert; Fournier, Pierre Simon; Major, Thomas; Muller, J. S; Muller, T. M. Jr; Borra, Giovanni Battista. London, 1753. 51. E-Book.

Figure 33. Frearson, Andy. Lebbeus Woods, October 2012. 2017. Web. <https://www.dezeen. com/2012/10/31/lebbeus-woods-1940-2012/>

Figure 34. Woods, Lebbeus. Photon Kite, 1988. 2017. Web. < https://architizer.com/blog/ inspiration/industry/lebbeus-woods-sfmoma/>

Figure 35. Woods, Lebbeus. Zagreb Free Zone, 1992. 2017. Web. < http://www.nytimes. com/2012/11/01/arts/lebbeus-woods-unconventional-architect-dies-at-72.html>

Figure 36. Woods, Lebbeus. Berlin Free Zone, 1990. 2017. Web. < http://www.resonantcity.net/ lebbeus-woods-architect/>

Figure 37. Lebrecht Music and Arts Photo Library/Alamy. Lynn Chadwick in his studio, 1950. 2017. Web. < http://www.telegraph.co.uk/culture/books/bookreviews/10895224/Lynn-Chadwickby-Michael-Bird-review-incisive-and-admirably-even-handed.html>

Figure 38. Chadwick, Lynn. Drawings for Sculpture, 1956. 2017. Web. < http://www.artnet.com/ artists/lynn-chadwick/drawings-for-sculpture-csSKVv40XDui5lXfRHpqsw2>

Figure 39. Chadwick, Lynn. Conjunction, 1953. 2017. Web. < http://eye-likey.blogspot. co.nz/2014/11/check-out-beautiful-shapes-of-this-mid.html>

Figure 40. Chadwick, Lynn. Conjunction V, 1958. 2017. Web. <http://www.osbornesamuel.com/ artists/lynn-chadwick-2/> 
Figure 41. Norm. Daniel Libeskind, 2013. 2017. Web. <http://normblog.typepad.com/ normblog/2013/06/an-interview-with-daniel-libeskind-.html>

Figure 42. Libeskind, Daniel. Berlin "City Edge" Competition, 1987. Berlin, Germany. 2017. Web. < http://www.frac-centre.fr/collection/collection-art-architecture/index-des-auteurs/auteurs/ projets-64.html?authID=115\&ensembleID=321>

Figure 43. Libeskind, Daniel. Model, Berlin City Edge, 1987. Berlin, Germany. 2017. Web. < http://books.openedition.org/editionscnrs/4291?lang=es>

Figure 44. Libeskind, Daniel. Urban conception of detail and structure, Berlin City Edge, 1987. Berlin, Germany. 2017. Web. < http://www.frac-centre.fr/_en/index-authors/rub/rubprojects-317.ht ml?authID=115\&ensembleID=321\&oeuvreID=1753>

Figure 45. Miss, Mary. Profile photograph. N.d. 2017. Web. < https://creativedisturbance.org/ people/mary-miss/>

Figure 46. Miss, Mary. Veiled Landscape, 1979. Lake Placid, New York. 2017. Web. < http:// marymiss.com/projects/veiled-landscape/

Figure 47. Miss, Mary. PERIMETERS/PAVILIONS/DECOYS, 1977. Roslyn. 2017. Web. <http:// marymiss.com/projects/perimeterspavilionsdecoys/>

Figure 48. Miss, Mary. PERIMETERS/PAVILIONS/DECOYS, 1977. Roslyn, New York. 2017. Web. < http://marymiss.com/projects/perimeterspavilionsdecoys/>

Figure 50. Pichler, Walter. Walter Pichler with his work. Drawings, Sculpture, Buildings. Pichler, Walter. Princeton Architectural Text, 1993. 5. Book.

Figure 51. Pichler, Walter. Installation in studio. Drawings, Sculpture, Buildings. Pichler, Walter. Princeton Architectural Press, 1993. 24-25. Book.

Figure 52. Pichler, Walter. House for the Woman, 1984. Drawings, Sculpture, Buildings. Pichler, Walter. Princeton Architectural Press, 1993. 160. Book.

Figure 53. Pichler, Walter. Woman in Metal, 1990. Drawings, Sculpture, Buildings. Pichler, Walter. Princeton Architectural Press, 1993. 73. Book. 
